\title{
JAROSLAV BIDLO A PRAŽSKÁ UNIVERZITA: K POČÁTKŮM ČESKÉ HISTORICKÉ SLAVISTIKY
}

\author{
MAREK ĎURČANSKÝ
}

\author{
JAROSLAV BIDLO AND THE UNIVERSITY IN PRAGUE: ON THE BEGINNINGS \\ OF CZECH HISTORICAL SLAVISTICS
}

This study deals with the earliest days of historical Slavistics at the Czech university in Prague and its perhaps most important representative, Jaroslav Bidlo (1868-1937). It follows his connection with the Prague university since his studies, when he belonged to the oldest generation of the so-called Goll's school of historical sciences, through his stays at universities in Krakow, Moscow, and Petersburg, and the development of his academic career from habilitation to full professorship in 1910. Also included is an overview of Bidlo's teaching and organising activities at the Prague university. Bidlo's career culminated when he was elected dean of the Faculty of Philosophy (1915/1916) and later, when in the 1930s he was for three years active in the academic senate. Bidlo's interwar activities at the Charles University clearly show how an originally rather marginal research field could, due to changes in the geopolitical situation, become prominent and enjoy full state support.

Keywords: Jaroslav Bidlo - historical Slavistics - Czech university in Prague - Charles University - Faculty of Philosophy - Goll's school

DOI: $10.14712 / 23365730.2019 .17$

\section{Úvod. Prameny a literatura}

Jaroslav Bidlo, profesor obecných dějin se zaměřením na dějiny východní Evropy a Balkánského poloostrova, stojí v obecném povědomí ve stínu svých generačních souputníků Josefa Pekaře, Josefa Šusty a Václava Novotného. Bylo tomu tak už v době, kdy všichni jmenovaní působili zároveň jako ředitelé historického semináře filozofické fakulty České univerzity Karlo-Ferdinandovy, respektive Univerzity Karlovy, občas za součinnosti některého z dalších historiků (zejména Kamila Krofty a Josefa Vítězslava Šimáka). ${ }^{1}$ Od akademického roku 1911/1912 až do smrti Václava Novotného o více než dvacet let později

1 Všichni uvedení ředitelé Historického semináře české univerzity se na rozdíl od Bidla už dočkali knižních biografí, byt' v některých případech jsou knihy zaměřeny jen na některou stránku jejich činnosti. Srov. Zdeněk Kalista, Josef Pekař, Praha 1994; Josef Hanzal, Josef Pekař. Život a dílo, Praha 2002; Jiří Lach, Josef Šusta 1874-1945. A History of a Life, a Life in History, Olomouc 2003; k Šustovi také Josef BlümL, Josef Šusta, Úvahy o světových dějinách, Praha 2006; Jaroslava Hoffmannová, Václav Novotný. Život a dílo univerzitního profesora českých dějin, Praha 2014; Jindřich DeJMEK, Historik v čele diplomacie: Kamil Krofta. Studie z dějin československé zahraniční politiky v letech 1936-1938, Praha 1998; Naděžda Morávková, Plzeňan Kamil Krofta, Plzeň 2016; Hana KÁBovÁ, Josef Vitězslav Šimák. Jeho život a dílo se zvláštním zřetelem $k$ historické vlastivědě, České Budějovice 2013. 
tvořili Pekař, Šusta, Bidlo a Novotný jádro pražské českojazyčné univerzitní historiografie. Všichni náleželi k nejstarší generaci Gollových žáků a studovat začínali na přelomu 80. a 90. let 19. století, v období intenzivního rozvoje české univerzity po rozdělení v roce 1882. Přes veškeré disharmonie, z nichž některé budou ještě zmíněny, měla tato „silná čtyřka“2 na vývoj české historiografie zásadní vliv. Nešlo samozřejmě pouze o působení na univerzitě, ale také o významné posty v domácích i mezinárodních vědeckých institucích. Cílem předkládané studie je ovšem sledování Bidlova vztahu pouze k pražské univerzitě, a to $\mathrm{v}$ kontextu historických oborů, $\mathrm{v}$ jejichž rámci po nedlouhém působení Konstantina Jirečka de facto rekonstituoval českou historickou slavistiku, a to na podstatně širším základu.

Považuji za užitečné na úvod ve stručnosti rekapitulovat literaturu a prameny, které jsou uloženy v řadě různých archivních fondů v archivech a knihovnách nejen v České republice.

Vedle článků k jubileím, ${ }^{3}$ nekrologů ${ }^{4}$ a nečetných všeobecně zaměřených biografických texti̊ ${ }^{5}$ a medailonů byla doposud Jaroslavu Bidlovi v české odborné literatuře věnována pozornost hlavně v souvislosti s nejstarším z jeho životních témat - dějinami Jednoty bratrské v raném novověku ${ }^{6}$ - a s jeho organizačními aktivitami, ${ }^{7}$ př́ípadně vztahem $\mathrm{k}$ jiným historikům. ${ }^{8} \mathrm{~V}$ mezinárodním měřítku je připomínán díky svému př́nosu $\mathrm{k}$ byzantologii

2 Parafrázuji Otakara Odložilíka, jehož deníkový záznam reagující na Bidlovo úmrtí svědčí o tom, že generace jejich žáků dlouholeté ředitele Historického semináře takto opravdu vnímala: „Zbude po něm prázdno, protože je už třetí z té silné čtveřice, která fakultou tak dlouho vládla." Milada Sekrrkoví (ed.), Otakar Odložilík, Deníky z let 1924-1948, I, 1924-1939, Praha 2002, s. 734.

3 Václav Placht, Jaroslav Bidlo, Kostnické jiskry 72/40, 2. 12. 1987, s. 4; Daniela BrádLerovÁ, Jaroslav Bidlo, Akademický bulletin 2012, č. 2, s. 32 .

4 Milada PAuloví, K uctění památky Jaroslava Bidla, Český časopis historický (dále ČČH) 44, 1938, s. 30-40; Josef Macůrek, Jaroslav Bidlo, Naše věda 19, 1938, s. 235-238; TÝž, Jaroslav Bidlo, Ročenka Slovanského ústavu 10, 1937, s. 223-231; Josef TichÝ, Jaroslav Bidlo, Ziemia Lesczyńska 1937, s. 242-250; Jan SLAvík, Jaroslav Bidlo a slovanské dějepisectví u nás, Slovanský přehled 29, 1937, s. 309-314, 320-322.

5 Zdeněk ŠıMEČEK, Bidlo Jaroslav, in: Milan Kudělka - Zdeněk Šimeček a kol., Československé práce o jazyce, dějinách a kultuře slovanských národů od r. 1760. Biograficko-bibliografický slovník, Praha 1972, s. 49-51; Martin Nechvátal, Jaroslav Bidlo (1868-1937), in: Sborník k dějinám 19. a 20. století IX, Praha 1984, S. 105-122; Josef MACŮREK, Jaroslav Bidlo, Sborník prací Filozofické fakulty Brněnské univerzity, řada C 46, 1997, s. 165-179; Marek ĎurČAnskÝ, Jaroslav Bidlo, in: Roman Baron - Roman Madecki a kol., Česká polonistická studia: tradice a současnost (filologie - historie - politologie - právo), Praha 2014, s. 383-388; Marek ĎurčAnský - Roman BARon, Jaroslav Bidlo, in: Czeskie badania nad Polską w kontekście Europy Środkowej i Wschodniej, Praha 2016, s. 425-429.

6 Roman BARON, Bracia czescy w Polsce w świetle prac Jaroslava Bidla: z rozważań nad problemem komunika$c j i$, in: Anna Paner - Wojciech Iwańczak (edd.), Rola komunikacji i przestrzeni w średniowiecznych i wczesnonowożytnych dziejach Czech i Polski, Gdańsk 2008, s. 204-215.

7 Marek DuurČAnský, Jaroslav Bidlo jako osoba veřejná, in: Dagmar Blümlová a kol. (edd.), Čas optimismu a ctižádostivých nadějí. Prezentace a reprezentace české vědy a kultury v prvním desetiletí samostatného státu (1918-1928), České Budějovice 2009 (=Jihočeský sborník historický, Supplementum I), s. 57-66.

8 Václav VeBer, Jaroslav Bidlo a Josef Macuirek, in: Střední a východní Evropa v krizi 20. století, Praha 1998, s. 141-148; TÝž, Jaroslav Bidlo a Josef Macưrek, in: Josepho Macůrek viginti lustra complenti oblata, Brno 2001, s. 16-22; Marek ĎurČAnskÝ, Jaroslav Bidlo a Gollova škola, in: Josef Blüml - Dagmar Blümlová - Bohumil Jiroušek (edd.), Jaroslav Goll a jeho žáci, České Budějovice 2005, s. 439-449; Daniela BrÁDLERovÁ Jan HÁlek, Osobní a profesní vztah Milady Paulové a Jaroslava Bidla na pozadi jejich vzájemné korespondence, Acta Universitatis Carolinae - Philosophica et historica 1-2/2002, Z pomocných věd historických XVI, Praha 2007, s. 553-569; Roman BARON, Z kontaktów polskich i czeskich elit społeczno-politycznych na przetomie XIX i XX wieku (wybrane zagadnienia), in: týž, Między Polską i Czechami. W optyce historyka z Brna, Toruń 2009, s. 157-166; Marek DurČAnSKÝ, Historyk Jaroslav Bidlo (1868-1837) - tącznik między krakowską szkoła historyczna i czeska szkoła historyczna Jaroslava Goll (1846-1929), in: Piotr Biliński - Paweł Plichta (edd.), Krakowska szkoła historyczna a Polskie Towarzystwo Historyczne. Studia historiograficzne, Warszawa - Kraków 2017, s. 47-59. 
a zejména ke koncepci dějin středovýchodní Evropy ${ }^{9}$. Středo- a východoevropský kontext Bidlova působení reflektují také texty zaměřené na průběh jeho studijních pobytů a cest. ${ }^{10}$ V posledních dvou desetiletích byly také editovány Bidlovy autobiografické texty a několik souborů jeho korespondence s jinými, zejména polskými historiky. ${ }^{11}$ Právě autobiografické texty a osobní korespondence umožňují nahlédnout za strohou mluvu úředních písemností a tisků.

Bidlovi je také věnována pozornost v př́slušných kompendiích zaměřených na dějiny historiografie a slavistiky, přičemž bývá v obecných rysech nastíněno i jeho univerzitní působení. ${ }^{12}$ Zatím nejpodrobnější vypsání Bidlovy univerzitní kariéry, zejména jejích počátků, lze nalézt v monografii Karla Kazbundy k dějinám „stolice dějin na pražské univerzitě“. ${ }^{13}$ Kazbunda prritom vycházel nejen z materiálů univerzitního archivu, ale také vídeňského ministerstva kultu a vyučování. Naopak neměl k dispozici množství pramenů

9 Milan KudĚLKa, Dějiny Slovanstva a východni Evropy v pojetí Jaroslava Bidla, Slezský sborník 72, 1974 , s. 1-16; Radomír VLČEK, Jaroslav Bidlo. K vývoji historiografických názorů na dějiny Slovanstva, Slavia 62, 1993, s. 385-390; Marco Clementi, Iaroslav Bidlo e Josef Macurek. La storia Cecoslovacca e il problema dell' unita dei popoli slavi (1900-1998), in: Nuova Rivista Storica 83/2, 1999, s. 359-388; Lubomíra HavlíKovÁ, K počátkùm české a slovenské byzantologie. P. J. Šafařik-J. Bidlo-M. Weingart, in: Česko-slovenská vzájemnost i nevzájemnost, Brno 2000, s. 140-146; Aleš HraBovskÝ, Jaroslav Bidlo jako historik východních dějin, in: Historie 2003. Celostátní vědecká konference, Pardubice 2004, s. 233-267; Jitka Komendové, Středověká Rus a úskali Bidlovy koncepce Dějin Slovanstva, in: Dominik Hrodek (ed.), Slovanství ve středoevropském prostoru. Iluze, deziluze a realita. Pardubická konference 22.-24. dubna 2004, Praha 2004, s. 214-219; Radomír VLČEK, Jaroslav Bidlo - $k$ formování českého dějepisného diskursu o minulosti Ruska, in: Česko-ruské vztahy v 19. a 20. století = Češsko-rossijskije otnošenija v 19-20 vekach, Praha 2011, s. 313-330; Vladimír GonĚc, Hvězdná hodina Jaroslava Bidla?, in: Solitér. Pocta historikovi Václavovi Veberovi, Praha 2012, s. $353-367$.

10 Bohumil JiroušEK, Studijní cesta Jaroslava Bidla na Rus v letech 1897-1898, Scientific Papers of the University of Pardubice, Series C, Faculty of Humanities, Supplement 3, 2000, s. 83-90; Marek ĎurČAnSKÝ, Krakovský pobyt Jaroslava Bidla ve školním roce 1892/93, in: Pocta Zdeňku Jelínkovi. Práce Muzea v Kolíně - řada společenskovědní VII, 2001, s. 47-55; тÝž, Szkoła historyczna Golla i jej przedstawiciele (Goll, Pekař, Bidlo) na tle stosunków czesko-polskich, in: Prace Komisji Historii Nauki PAU, t. VIII, Kraków 2007, s. 237-274; TÝž, Jaroslav Bidlo a jeho cesty do Polska, in: Petr Kaleta - Lukáš Novosad (edd.), Cestování Čechů a Poláků v 19. a 20. století. Sborník z mezinárodní vědecké konference (Praha, 6.-7. 9. 2007), Praha 2008, s. $143-151$.

11 Lubomíra HavlíKovÁ, Klasická studia a počátky české byzantologie (Z korespondence A. Salače a Jaroslava Bidla), Listy filologické 125, 2002, s. 102-109; Marek DuurČAnsKÝ (ed.), Jaroslav Bidlo: Moje styky s Gollem, in: Josef Blüml - Dagmar Blümlová - Bohumil Jiroušek (edd.), Jaroslav Goll a jeho žáci, České Budějovice 2005, s. 657-686; Piotr BiLIŃSKi - Marek ĎurČAnSKÝ (edd.), Korespondencja Stanisława Kota z Jaroslavem Bidlo, Odrodzenie i reformacja w Polsce 52, 2008, s. 239-267; тíž (edd.), Vzájemná korespondence Jaroslava Bidla a Stanisława Zakrzewského, Acta Universitatis Carolinae - Historia Universitatis Carolinae Pragensis (dále AUC-HUCP) 49/1, 2009, s. 95-111; тíž (edd.), Korespondencja Jana Ptaśnika z Jaroslavem Bidlo, Kwartalnik Historii Nauki i Techniki 56, 2011, s. 7-44; Marek DurČANsKÝ (ed.), Korespondencja Władysława Semkowicza i Jaroslava Bidlo. Kartka z historii stosunków naukowych polsko-czeskich w okresie międzywojennym, Krakowski Rocznik Archiwalny 18, 2012, s. 131-154; Libor BERnÁT (ed.), Korespondence Jaroslava Bidla s Jánem Kvačalou, Středočeský sborník historický 40, 2014, s. 215-242; TÝž, Ján Kvačala a Gollova škola vo svetle vzájomnej korešpondencie, Bratislava 2017; Daniela BrÁdLerovÁ - Jan HáleK (edd.), Jaroslav Bidlo - Milada Paulová: Střet generací? Paměti a vzájemná korespondence zakladatelủ české byzantologie a slovanských studií, Praha 2014; Marek ĎURČANSKÝ - Sebastian GRUDZIEŃ (edd.), Vzájemná korespondence Henryka Batowského a Jaroslava Bidla, AUC-HUCP 56/2, 2016, s. 99-118.

12 Milan KUDĚLKA - Zdeněk ŠIMEČEK - Vladislav ŠŤAstnÝ - Radoslav VEČERKA, Česká slavistika od počátku 60. let 19. století do roku 1918, Praha 1997, zvl. s. 79-81 a 374-376; František Kutnar - Jaroslav MAREK, Přehledné dějiny českého a slovenského dějepisectví. Od počátkủ národní kultury až do sklonku třicátých let 20. století, Praha 1997, s. 544-547; Milan KUDĚLKA - Zdeněk ŠIMEČEK - Vladislav ŠŤASTNÝ - Radoslav VEČERKA, Československá slavistika v letech 1918-1939, Praha 1977, s. 357-361.

13 Karel Kazbunda, Stolice dějin na pražské universitě, III, Stolice dějin na české universitě od zř́zeni university do konce rakousko-uherské monarchie (1882-1918), Praha 1968. 
osobní povahy, respektive měl k výpovědní hodnotě pramenů tohoto typu značnou nedůvěru. Nezanedbatelné množství závažnějších písemností, zejména pamětí, deníků a souborů korespondence, bylo vydáno tiskem ve formě moderních edic. ${ }^{14}$

V relativně obsáhlém a dobře dochovaném osobním fondu Jaroslava Bidla, uloženém v Masarykově ústavu a Archivu akademie věd, se vztahují bezprostředně k působení na univerzitě především osobní doklady ${ }^{15}$ a př́slušná složka $\mathrm{k}$ veřejnému působení, ${ }^{16}$ dílč́m způsobem pak řada dalších dokumentů, zejména korespondence. Materiál uložený v Archivu Univerzity Karlovy zahrnuje vedle osobní složky J. Bidla ${ }^{17}$ také záznamy o jeho studiu (katalogy posluchačů, rigorózní protokoly, matrika doktorů) i pozdějším pedagogickém a organizačním působení v rámci akademické obce. ${ }^{18}$ Protokoly ze zasedání profesorského sboru filozofické fakulty jsou pak hlavním zdrojem informací pro rekonstrukci Bidlova organizačního působení na půdě univerzity.

\section{Původ a vzdělání před nástupem na univerzitu}

Údaje o původu Jaroslava Bidla byly dosud přejímány z osobních dokumentů nebo ze starší literatury. Pro účely tohoto článku byla provedena základní rešerše v matrikách, aby bylo možné lépe objasnit jeho rodinné zázemí. Jaroslav Bidlo totiž pocházel doslova z učitelské rodiny a na jeho př́kladu je prímo možné symbolicky ilustrovat kořeny a vzestup české inteligence v 19. století. Otec Jaroslava Bidla Augustin Blažej (narozen 3. února 1841 v Lipolticích $)^{19}$ byl učitelem v Záboří nad Labem, obci s prosperujícím cukrovarem, a posléze v městečku Uhliřských Janovicích. Také historikův dědeček Jan Nepomuk Bidlo (narozen 8. záŕí 1806 ve Vysokém Chvojně) ${ }^{20}$ byl venkovským učitelem, ovšem v o poznání menších Lipolticích nedaleko Přelouče. Pradědeček Jaroslava Bidla Václav byl chalupníkem ve Vysokém Chvojně. ${ }^{21}$ Geograficky tak byly rodiny Bidlových předků vázány na oblast někdejších komorních panství ve středním Polabí zhruba mezi Kolínem a Pardubicemi.

Otec Jaroslava Bidla Augustin působil v Záboří od svých 26 let nejprve jako farní a později jako řídící učitel. Pocházel z velké rodiny a vzdělání se mu dostalo díky jeho nespornému nadání. V roce 1889 byl jmenován řídícím učitelem v Uhliřských Janovicích, kam se rodina odstěhovala a kde působil až do odchodu na odpočinek v roce 1904. Podzim života

14 Míra jejich výpovědní hodnoty ve vztahu k J. Bidlovi je samozřejmě různá. Zásadní význam v tomto ohledu mají následující: Josef MACŮREK, Úvahy o mé vědecké činnosti a vědeckých pracích, Brno 1998; Zdeněk Kalista, Po proudu života (2), Brno 1996; Daniela Brádlerová - Jan HÁlek (edd.), Drahý pane kanclérí... Vzájemná korespondence Milady Paulové a Přemysla Šámala, I-II, Praha 2011-2012; Bohumil JIROUŠEK, O vzpomínkách Josefa Klika, Jihočeský sborník historický 66-67, 1997-1998, s. 134-138 (součástí je edice Klikových vzpomínek na J. Bidla).

15 MÚA A AV ČR, fond Jaroslav Bidlo, kart. 1, i. č. 1.

16 Tamtéž, kart. 25, i. č. 364.

17 Archiv Univerzity Karlovy, fond Filozofická fakulta Univerzity Karlovy, kart. 10, i. č. 102.

18 Jsou citovány dále na př́slušných místech.

19 SOA Zámrsk, fond Sbírka matrik Východočeského kraje, i. č. 5407, sign. 4421, Matrika narozených farního úřadu Lipoltice 1844-1877, p. 57.

20 SOA Zámrsk, fond Sbírka matrik Východočeského kraje, i. č. 10746, sign. 539, Matrika narozených farního úřadu Vysoké Chvojno 1785-1815, p. 29.

21 Tamtéž. 
prožil v Kolíně, kde také 5. února 1917 zemřel. Manželka Antonie, dcera Josefa Krátkého z Týnce nad Labem (Labské Týnice), jej přežila o více než dvě desetiletí. Augustin Bidlo byl mimo jiné výborným houslistou a sbormistrem..$^{22}$ Nestranil se ani společenského života - tak utkvěl v paměti významnému českému průmyslníkovi Hanuši Karlíkovi, který působil jako ředitel cukrovaru v Záboří v letech 1874-1881.23

Jaroslav Josef Bidlo se narodil v Záboří nad Labem 17. listopadu 1868 a byl pokřtěn hned následujícího dne. ${ }^{24}$ Dětství trávil v rodné obci, kde také chodil do obecné školy. Tam měl podle vlastních vzpomínek z otcových výkladů získat první znalosti z českých dějin, které jej pak ,zajímaly tak, že [...] o nich mluvil s matkou, hlavně při vaření, a ona [...] vědomosti rozmnožovala všelijakými podrobnostmi “25. Gymnázium studoval v Hradci Králové. Zde své dějepisné záliby mohl přinejmenším částečně rozvinout, zejména ve vyšších ročnících. Mezi Bidlovými učiteli nechyběly zajímavé osobnosti. Dějepis jej v kvartě učil Jan Bohuslav Miltner, autor spisů o obraně Vídně před Turky, respektive studií a edic k regionálním dějinám Slánska. Bližší vztah získal ke třídnímu profesorovi Aloisi Gromanovi, což jej vedlo k intenzivnějšímu studiu jazyků (Groman učil vedle latiny a řečtiny také němčinu a češtinu), zároveň ale získal některé návyky, s nimiž se musel později vyrovnávat, $\mathrm{v}$ tomto př́ípadě například sklon $\mathrm{k}$ př́lišs doslovnému překladu. Na tyto profesory Bidlo vzpomínal, ${ }^{26} \mathrm{z}$ dochovaných vysvědčení se ale také dozvídáme, že se jako $s$ učitelem př́rodopisu a matematiky setkal s legendárním „excentrikem“ Jakubem Hronem Metánovským. Bidlo maturoval na jaře 1887 se samými výbornými a chvalitebnými, pouze z němčiny byl oceněn „dobře“. 27

Po maturitě nastoupil do královéhradeckého biskupského semináře. Jednalo se bezesporu v první řadě o přání rodičů. Sám Bidlo s odstupem uváděl: „Od samých počátkư mých studií jsem byl jaksi předurčen za kněze. Několikrát sice se mi zablýskla během studii myšlenka státi se středoškolským profesorem, ale vcelku jsem si vi̊bec o tom, čím budu, nepřipouštěl žádných myšlenek. Teprve když bylo po maturitě, musel jsem se rozhodnouti.“28 Ve skutečnosti se jistě jednalo o souhru řady důvodů, které sám Bidlo podrobně vypočetl $\mathrm{v}$ jedné verzi svých vzpomínek: svou roli sehrála osobnost Bidlova strýce z matčiny strany (faráře ve Ždánicích a poté $\mathrm{v}$ blízkém Týnci nad Labem), vliv faráře $\mathrm{v}$ Záboří na Bidlovy rodiče i otázka finančních nákladů na studia Jaroslava Bidla a jeho bratra Bohumila, již by pobyt jednoho z nich na církevním ústavu značně zjednodušil. ${ }^{29}$ Dva roky strávené v semináŕi ale zpětně nehodnotil jako ztracený čas, je ovšem těžké určit, kteří profesoři na něj nejvíce působili, protože - na rozdíl od studia na gymnáziu - se o tom v žádném z autobiografických textů nezmiňuje. Konstatuje pouze, že nabyl systematičnosti a sebekázně při učení, nezbytné pro soustavné studium, důkladněji se vzdělal v latině a zvláště si cenil zvládnutí

22 Není-li uvedeno jinak, jsou údaje převzaty z úvodu k edici části pamětí, které Augustin Bidlo sepsal na přání svého syna. Jaroslav BidLo (ed.), Z pamétí Augustina Bidla o chrudimské hlavni škole a reálce v letech 1853 $a z ̌ ~ 1855$, in: Vlastivědný sborník východočeský 6, Chrudim 1938, s. 4-26.

23 Paměti Dra Hanuše Karlika, Praha 1927, s. 52.

24 Jeho kmotrami byly dcera týneckého mlynáře Václava Pernera Antonie, teta z matčiny strany Karolina Krátká, rovněž z Týnce nad Labem, a strýc z otcovy strany Josef Bidlo, učitel v Miletíně. Státní oblastní archiv Praha, fond Sbírka matrik, Matrika narozených farnosti Záboří nad Labem 1864-1918, p. 18v-19r.

25 D. Brádlerová - J. Hálek (edd.), Jaroslav Bidlo - Milada Paulová. Střet generací?, s. 70.

26 Tamtéž, s. 71.

27 Vysvědčení z gymnázia jsou uložena v MÚA, fond J. Bidlo, kart. 1, i. č. 1.

28 D. Brádlerová - J. Hálek (edd.), Jaroslav Bidlo - Milada Paulová. Střet generací?, s. 49.

29 Tamtéž, s. 74n. 
logiky potřebné pro scholastické výklady a katolickou dogmatiku. Tyto schopnosti se mu později hodily při psaní prací o Jednotě bratrské. ${ }^{30}$ Pochybnosti o zvolené životní cestě ale probleskovaly v jeho korespondenci s rodiči již během pobytu v semináři: ,V sobotu oblékl jsem na sebe po prve kleriku a dojmy s tím spojené a vše ostatni dohromady podivnou jakous náladu ve mně vzbuzují. Doufám však, že později zase veselost’ nabude vrchu jako dřvive, ale to snad již nebude, až doma budu. “31

Také Bidlovo rozhodnutí vystoupit po druhém ročníku z kněžského semináře bylo důsledkem vícero okolností. Tou nejzávažnější byla bezesporu změna v jeho psychickém nastavení, „vanutí velikého světa a jeho radosti“", které plněji pocítil o prázdninách roku 1889, kdy trávil léto u př́buzných na Jičínsku a Mladoboleslavsku toulkami po Prachovských skalách a dalších pěkných místech. Své sehrál také názor jeho kmotra a strýce, řídícího učitele v Miletíně Josefa Bidla, který oceňoval jeho studijní schopnosti a nadání. Důležitou vnější okolností pak bylo povolání Augustina Bidla na lépe finančně zajištěné místo řídícího učitele v Uhlířských Janovicích. Tím byly otupeny případné námitky rodičů. Po krátkém duševním boji na začátku třetího ročníku Jaroslav Bidlo 8. října 1889 oznámil překvapenému řediteli hradeckého semináře svůj odchod a hned následujícího dne odjel do Prahy, aby se mohl zapsat k vysokoškolskému studiu. ${ }^{32}$

\section{Studium na pražské univerzitě}

Na filozofickou fakultu české univerzity se Bidlo zapsal s jistým váháním, ale patrně ne velkým. Lze věřit jeho vzpomínce, že nedbal na varování děkana Konstantina Jirečka, který ho přesvědčoval o nedostatku míst pro kandidáty středoškolské profesury a navrhoval alternativu v podobě právnické fakulty. ${ }^{33} \mathrm{~S}$ čerstvou zkušeností z memorování textů v semináři a s vědomím učitelské tradice své rodiny $\mathrm{k}$ tomu mohl mít ostatně vícero důvodů. Zajímavým momentem z prvních kroků Jaroslava Bidla na půdě filozofické fakulty je právě setkání s profesorem dějin slovanských národů Jirečkem, jehož přednášky si sice zprvu nezapsal, měl ovšem jednou převzít výuku v jeho oboru. Bidlovu nepřítomnost na málo navštěvovaných Jirečkových přednáškách ve svých vzpomínkách glosoval i Josef Šusta. ${ }^{34}$ V Bidlově pozůstalosti je ovšem dochováno potvrzení (,vysvědčení“), že v zimním semestru 1890/1891 navštěvoval Jirečkovy přednášky o dějinách křǐžových výprav a složil příslušné kolokvium s výborným prospěchem, ${ }^{35} \mathrm{v}$ následujícím roce pak měl zapsánu jeho přednášku o byzantských dějepisných pramenech a vedle toho absolvoval i další jeho přednášky (viz př́lohu č. 1). Bidlo Jirečkovy badatelské výkony po jeho odchodu na vídeňskou univerzitu sledoval a referoval o nich (zejména na stránkách Českého časopisu historického ${ }^{36}$ ). Věnoval

30 Tamtéž, s. 49.

31 J. Bidlo rodičům, 1. prosince 1887, Hradec Králové. MÚA, fond J. Bidlo, kart. 2, i. č. 10.

32 Podrobně D. BrÁdlerová - J. HÁlek (edd.), Jaroslav Bidlo-Milada Paulová. Střet generací?, s. 75n.

33 D. Brádlerová - J. HÁlek (edd.), Jaroslav Bidlo - Milada Paulová. Střet generací?, s. 51. Osvědčení o zápisu na filozofickou fakultu podepsané Jirečkem a datované 15. ř́jna 1899 je dochováno v MÚA, fond J. Bidlo, kart. 1 , i. č. 1 .

34 Josef Šusta, Mladá léta učňovská a vandrovní. Praha-Videň- ̌̌ím. Vzpomínky, II, Praha 1963, s. 43.

35 Je datováno 6. března 1891 a podepsáno K. Jirečkem. MÚA, fond J. Bidlo, kart. 1, i. č. 1.

36 Jaroslav Biduo, [rec.] Constantin Jireček, Geschichte der Serben. Erster Band (bis 1371), V. Allgemeine Staatengeschichte. Herausgegeben von Karl Lamprecht. I. Abteilung: Geschichte der europäischen Staaten, 
mu i několik jubilejních článků u př́ležitosti jeho šedesátky ${ }^{37}$ a dva zasvěcené nekrology. ${ }^{38}$ Nemůžeme tedy říci, že by mezi oběma představiteli historické slavistiky jako univerzitního oboru na české univerzitě nebyly žádné vazby, rozhodně ale měly daleko k intenzitě a hloubce Bidlova vztahu k jeho dalším učitelům.

Přednášky si Bidlo od prvního ročníku zapisoval tak, aby co nejlépe pokryl spektrum předmětů důležitých pro budoucí kariéru středoškolského učitele. Vedle samotné historie tak intenzivně studoval zeměpis, v němž se cítil slabý. Přednášky Jana Palackého jej ovšem naprosto zklamaly, stejně jako řadu dalších budoucích významných historiků. ${ }^{39}$ Ve shodě s Josefem Šustou také vzpomínal na zásadní roli Palackého asistenta Václava Švambery, pozdějšího profesora prrírodovědecké fakulty, pro tehdejší posluchače. ${ }^{40}$ Posléze - sám už v roli mimořádného profesora obecných dějin - podpořil jeho návrh na mimořádnou profesuru. ${ }^{41}$

Obecně lze říci, že se skladba Bidlem zapsaných přednášek př́liš neodlišovala od toho, čím prošli jeho vrstevníci, důležití jak obecně, tak přímo ve vztahu $\mathrm{k}$ němu, např́iklad Václav Novotný studující v letech 1887-1891, Josef Pekař (studium v letech 1888-1892) nastoupivší o rok dřive než Bidlo nebo Josef Šusta (1891-1898).42 Také oni absolvovali řadu jazykovědných přednášek, zejména bohemistických Jana Gebauera a Martina Hattaly, méně germanistických Emanuela Mourka a Arnošta Krause. Měli možnost seznámit se s oběma profesory filozofie, Josefem Durdíkem a Tomášem Masarykem. Vesměs se jednalo o přednášky vypisované těmito „exponovanými přednašeči“ pro širší okruh posluchačů filozofické, respektive právnické fakulty. ${ }^{43} \mathrm{Ne}$ zcela všichni z Bidlových kolegů si stejně jako on zapisovali přednášky z estetiky Otakara Hostinského nebo na pedagogickou průpravu zaměřené výklady docenta Petra Durdíka. ${ }^{44}$ Bidlo byl ovšem ve srovnání se svými kolegy historiky výjimkou svou intenzivní lingvistickou př́pravou. Později vzpomínal, že na jeho rozhodování při zápisu prvních přednášek měla významný vliv konzultace s právě absolvovavším filologem Janem Jakubcem, pozdějším profesorem filozofické fakulty, jehož bratr Alois byl Bidlův spolužák z hradeckého gymnázia. Bidlo jako student poslouchal Gebauerovy přednášky, respektive pracoval $\mathrm{v}$ jeho slovanském semináři po celou dobu

ČČH 18, 1912, s. 80-86; TY̌ž, [rec.] C. Jireček, Staat und Gesellschaft im mittelalterslichen Serbien. Studien zur Kulturgeschichte des 13.-15. Jahrhunderts. Erster Teil, zweiter Teil, ČC̆ H 20, 1914, s. 203-209; TÝž, [rec.] Konst. Jireček, Staat und Gesellschaft im mittelalterlichen Serbien. Část třetí, ČČH 21, 1915, s. 84-85; TÝž, [rec.] Constantin Jireček, Geschichte der Serben. Zweiter Band, erste Hälfte (1371-1537), ČC̆H 25, 1919, s. $98-100$.

37 Jaroslav BiDLo, Konstantin Jireček, Časopis Českého musea (dále ČČMM) 88, 1914, s. 245-256; TÝž, Konstantin Jireček, ČC̆H 20, 1914, s. 364-366.

38 Jaroslav BidLo, Konstantin Jireček, Věstník České akademie věd a umění 27/7-8, 1918, s. 115-133; TÝž, Konstantin Jireček, Almanach České akademie věd a umění 28, 1918, s. 158-168; TÝž, Za Konstantinem Jirečkem, Lidové noviny č. 19, 19. 1. 1918; TÝž, Konstantin Jireček, ČMM 43-44, 1919-1920, s. 1-13.

39 Jiří Křesťan, Zdeněk Nejedlý. Politik a védec v osamění, Praha - Litomyšl 2012, s. 29; Josef KLIK (ed.), Listy úcty a prátelství. Vzájemná korespondence Jaroslava Golla a Josefa Pekaře, Praha 1941, s. 50; H. KẢBovÁ, Josef Vitězslav Šimák, s. 35.

40 J. Šusta, Mladá léta, s. 29-31; D. Brádlerová - J. HÁlek (edd.), Jaroslav Bidlo - Milada Paulová: Střet generaci? , s. 27-33, 42, 77n.

41 AUK, FF UK, kart. 2, i. č. 25, protokol ze zasedání profesorského sboru FF UK-F, 29. 11. 1906.

42 J. Hoffmannová, Václav Novotný, s. 61-74; Josef Hobzen, Př́spěvky a materiály k životopisu Josefa Pekaře, in: Rudolf Holinka (ed.), O Josefu Pekařovi, s. 292n; J. Šusta, Mladá léta, zejména s. 26-96.

43 J. Šusta, Mladá léta, s. 37.

44 O této dnes již téměř zapomenuté osobnosti srov. Ivo Tretera, Spor kolem habilitace Petra Durdika, AUC-HUCP 28/1, 1988, s. 133-146. 
svého studia, setkal se tu napríklad s budoucím významným editorem staročeských památek Václavem Flajšhansem ${ }^{45}$ a napsal seminární práci, která po úpravách vyšla tiskem. ${ }^{46}$ Pro analýzu věroučných textů z 16. století, jež využíval ve svých pracích o Jednotě bratrské, tak byl nejen po teologické, ale také po jazykové stránce nadprůměrně připraven.

Klíčovou součástí studia ale pro Bidla s ohledem na jeho další životní osudy samozřejmě byly přednášky a semináře historiků. Do Gollova semináře podle vlastních vzpomínek nebyl v prvním roce přijat, jelikož podmínkou bylo absolvování alespoň dvou semestrů historického studia. Stal se tak na další dva roky členem Emlerova paleografického semináře. Na Emlera vzpomínal v dobrém, podobně jako Josef Šusta, př́nos semináře ale hodnotil ve srovnání s Gollovým jako menší. ${ }^{47} \mathrm{~V}$ Emlerově semináři zpracovával Bidlo práci Čechy a Polsko v 11. a 12. století, která Golla zaujala, když si u něj Bidlo vyžádal související literaturu z knihovny historického semináŕe. Goll tehdy pracoval na monografii Čechy a Prusy ve středověku, což se odrazilo jak v tématech jeho přednášek, tak ve výběru pramenů rozebíraných $\mathrm{v}$ semináŕi. Bidlo se stal jeho členem ve třetím roce studia, kdy se zároveň zapsal do - mimochodem úplně poprvé odbývaného - semináře Antonína Rezka. 48 U Rezka se v seminární práci mohl vrátit k tematice Veleslavínova Kalendáře historického srovnáním jeho dvou vydání. Ačkoli se ale dočkal jejího otišš̌ní, sám s ní př́iliš spokojen nebyl a tématu se později už nevěnoval. ${ }^{49}$

V Gollově seminár̆i se v roce $1891 / 1892^{50}$ rozebíraly prameny $\mathrm{k}$ bitvě u Chlumce roku 1126, a poté $\mathrm{k}$ česko-polským vztahům za husitství s kritickým zaměřením na dílo Jana Długosze. Bidlo se pod jeho vedením a v souvislosti se svým dosavadním zájmem o Veleslavínův Kalendár historický zprvu zabýval problematikou církevních dějin 16. století. Výsledkem byla souborná recenze na tři knihy publikovaná v Athenaeu. ${ }^{51}$ Poté ale Goll směřoval jeho zájem ke starším polským dějinám: nechal jej na základě monografie Heinricha Zeissberga Die polnische Geschichtsschreibung im Mittelalter sepsat práci o dějinách polského dějepisectví až do Długosze, o němž měl Bidlo následně napsat heslo do Ottova slovníku naučného. ${ }^{52}$ Nepochybně tak převzal původní závazek samotného Golla, který byl v uvedeném akademickém roce zaneprázdněn povinnostmi děkana filozofické fakulty. Téma předznamenávalo Bidlovu studijní cestu do Krakova, o níž se v letním semestru již jednalo. ${ }^{53}$

45 D. Brádlerová - J. HÁlek (edd.), Jaroslav Bidlo - Milada Paulová: Střet generací?, s. 27, 78nn.

46 Jaroslav BidLo, Hláskoslovné a tvaroslovné zvláštnosti Hájkova Herbáre (z r. 1562) a Veleslavínova Kalendáre historického (z r. 1578), Listy filologické 21, 1894, s. 100-106, 203-212, 288-301, 378-391, 448-462.

47 D. BrÁdlerová - J. HÁlek (edd.), Jaroslav Bidlo - Milada Paulová: Střet generací?, s. 25n, 29n, 51n, 78n; J. Šusta, Mladá léta, s. 40-43, 65.

48 Bohumil JiRoušEK, Antonin Rezek, České Budějovice 2002, s. 80.

49 J. Bidlo, První a druhé vydáni Veleslavínova Kalendáre historického, Časopis Společnosti přátel starožitností českých 3, 1895, s. 25-28; D. Brádlerová - J. Hálek (edd.), Jaroslav Bidlo-Milada Paulová: Střet generací?, s. 52. Bidlovu studii navrhl Rezek na udělení stipendia, ovšem teprve poté, co na toto stipendium nereflektoval J. V. Šimák se svou seminární prací Wrangl v Čechách v r. 1647. H. KÁBovÁ, Josef Vitézslav Šimák, s. 31.

50 Seznam členů semináře v akademickém roce 1891/1892 na základě Gollovy zprávy uvádí K. KAzBundA, Stolice dějin, III, s. 61, pozn. 46. Byli jimi František Rejthárek, František Klíma, Jan Zítek, Jaroslav Bidlo, Josef Pekař, Karel Pešek a Antonín Doležal.

51 Srov. J. Bidlo [rec.], Al. Knöpfler, Die Kelchbewegung in Bayern unter Herzog Albrecht V.; K. Saftien, Die Verhandlungen Kaiser Ferdinand I. mit Papst Pius IV. über den Laienkelch und die Einführung desselben in Österreich; J. Hoffmann, Geschichte der Laienkommunion bis zum Tridentinum, Athenaeum 11, 1893, s. 22-25.

52 Ottưv slovník naučný, VII, Praha 1893, s. 686-687.

53 Bidlovy vzpomínky na práci v Gollově a Rezkově semináŕi srov. D. BrádlerovÁ - J. HÁlek (edd.), Jaroslav Bidlo - Milada Paulová: Střet generaci?, s. 33n., 52, 79-82; M. ĎurČAnskÝ (ed.), Jaroslav Bidlo, Moje styky s Gollem, s. 664-666. 
Dalším z Bidlových univerzitních učitelů v historických oborech byl stárnoucí Josef Kalousek ${ }^{54}$ který se stal také jedním z jeho zkoušejících při rigorózních zkouškách a společně s Gollem posuzoval jeho disertační práci Čeští emigranti v Polskuv době husitské a mnich Jeroným Pražský.

Hlavní rigorózní zkoušky skládal Bidlo 28. dubna 1894 z dějepisu a z latiny. Jeho zkoušejícími byli vedle Josefa Kalouska ještě profesor klasické filologie Jan Kvíčala a Jaroslav Goll. Ten před kolokviem ztrémovaného Bidla přesvědčil, aby zkoušku neodkládal a vrátil mu také peníze zaplacené za zkušební taxu. Vedlejší rigorózní zkoušky skládal Bidlo 11. října 1894 z filozofie. Jeho zkoušejícími byli Tomáš G. Masaryk a Josef Durdík, ale na rozdíl od skvělého výsledku hlavního rigoróza, tentokrát mohl být rád, že se mu zkoušku podařilo složit: „Ani u jednoho, ani u druhého jsem nerozuměl otázkám, zvláštěj jsem nevěděl, co chce Durdik, když se mě tázal, co je kritika. Měla to být otázka z logiky a mél jsem ř́ci, že kritika je úsudek. Abych nesedèl jako ryba, vykládal jsem Kantovu kritiku čistého rozumu. Co se mé ptal Masaryk, to už nevím, ale poněvadž jsem zase mluvil, abych dokázal, že něco umím, tedy mně oba dali dostatečnou. Durdik mně po rigorózu řekl, že mně proto tu otázku dal, poněvadž jsem s ním o prázdninách v Karlových Vařich mluvil o jeho kritikách o krásné literatuře, jež uveřejňoval v Osvětě. "55 Doktorská promoce Jaroslava Bidla se konala 16. ř́jna 1894. ${ }^{56}$ Jeho promotorem se stal Jan Gebauer, který byl mezi profesory filozofické fakulty u promocí na řadě, jak si Bidlo zjistil na děkanátu. Bál se pak oslovit s prosbou o převzetí čestné role promotora Golla, aby neurazil Gebauera, čímž se mu podařilo urazit Golla. ${ }^{57} \mathrm{U}$ př́ležitosti promoce si Bidlo nechal vytisknout promoční oznámení, což byl v pražských poměrech běžný zvyk, vzbudil tím ovšem údiv u jednoho ze svých krakovských učitelů. ${ }^{58}$

\section{Studium v zahraničí}

Poměrně běžnou součástí vysokoškolského studia, zvláště přípravy adeptů na budoucí akademickou kariéru, byl i na české univerzitě přelomu 19. a 20. století zahraniční pobyt. Bidlovi souputníci z řad historiků jej absolvovali většinou na německých univerzitách (Berlín, Mnichov, Lipsko), prípadně ve Vídni a v Římě, kde se podíleli na výzkumu ve vatikánském archivu. ${ }^{59}$ Zkušenost s polskojazyčnými univerzitami v Haliči (Krakov, Lvov) byla u historiků výjimkou, zdaleka to ovšem neplatilo u všech oborů, zejména u právníků. ${ }^{60}$ Těž-

54 K němu nejnověji Bohumil JiroušEK, Josef Kalousek. Historik v národní společnosti druhé poloviny 19. století, Praha 2018.

55 D. Brádlerová - J. HÁlek (edd.), Jaroslav Bidlo - Milada Paulová: Střet generací?, s. 43.

56 AUK, fond Matriky Univerzity Karlovy, i. č. 1, Matrika doktorů České Karlo-Ferdinandovy univerzity I, S. 341 .

57 D. BrÁdlerová - J. HÁleK (edd.), Jaroslav Bidlo - Milada Paulová: Střet generací?, s. 43, 92.

58 Lucjan Malinowski psal Gollovi 18. prosince 1894: „Ale otrzymuję kartę svatebnou! Myslil jsem, že Ph. C. Jaroslav Bidlo se žení, a on klade sobě za čest oznámiti, že bude povýšen na Dra phil! Jak jsem živ, poprvé vidím takovej lístek. Ich will das zur Erinnerung aufheben." Stanisława Sochacka (ed.), Listy Lucjana Malinowskiego do Jarosława Golla. Przyczynek do dziejów polsko-czeskich kontaktów naukowo-kulturalnych w drugiej połowie XIX wieku, Opole 1975, s. 161.

59 Přehledně Kateřina BlÁHová, České dějepisectví v dialogu s Evropou (1890-1914), Praha 2009, s. 47-85.

60 Mezi téměř třemi sty studentů s paralelní zkušeností z pražské (české i německé) a krakovské univerzity pro období 1850-1918 zdaleka převažují právníci. Vycházím z vlastního, dosud nepublikovaného prosopografického 
ko říci, nakolik Jaroslav Goll již ve chvíli, kdy svého žáka vysílal do Krakova, počítal s jeho budoucí akademickou dráhou. Spíše podle mého názoru mělo jít o sondování možností ve dvojím směru - jednak ohledně bližších kontaktů s krakovským akademickým prostředím, jednak př́ípadných inspirací př́ímo na poli univerzitní historiografie (zejména praktické fungování historického semináře). Součástí rozhodování byly bezpochyby Gollovy osobní kontakty, které měly jeho žákovi usnadnit průběh pobytu. Stará známost se Stanisławem Smolkou, kdysi Gollovým mladším spolužákem v semináři Georga Waitze v Göttingen a nyní vůdčí osobností „krakovské historické školy“, stejně jako prátelství s profesorem slovanské filologie Lucjanem Malinowským jsou známou věcí. ${ }^{61}$ Méně známé jsou Gollovy další osobní vazby, např́klad jeho pobyt v Krakově během Sjezdu polských lékařů a prrírodovědců v roce 1881 , který probíhal ve znamení česko-polského sbližení a kdy Goll navázal kontakt také $\mathrm{s}$ druhým $\mathrm{z}$ ředitelů krakovského historického semináře Wincentym Zakrzewským. ${ }^{62} \mathrm{~V}$ tomto ohledu tedy Bidlo nevyjížděl zcela do neznáma.

Průběhu jeho krakovského pobytu v akademickém roce 1892/1893 již byla věnována samostatná pozornost, shrňme tedy alespoň ve stručnosti to nejpodstatnější. Jak je z Bidlových pamětí a soudobé korespondence patrné, vnímal jako iniciátora své cesty do Krakova Golla, který byl ovšem tehdy děkanem fakulty. Patrně právě proto formálně podali návrh na poskytnutí podpory J. Bidlovi ve výši 100 zlatých ,z fondu bývalého sboru doktorského [...] ke studium na universitě Krakovské“ K. Jireček s A. Rezkem. Návrh byl 14. července 1892 profesorským sborem filozofické fakulty jednohlasně schválen. ${ }^{63}$ Souhlas rodičů, pro které studijní pobyt přece jen znamenal př́ípadné výdaje navíc, získal Bidlo v ř́ijnu téhož roku. Na konci ř́jna do Krakova skutečně odjel a 7. listopadu 1892 se zapsal ke studiu.

Ústředními postavami jeho pobytu $v$ Krakově byli oba ředitelé historického semináře Jagellonské univerzity Smolka a Zakrzewski, s nimiž se vedle výuky setkával také při neformálních večerních setkáních „Historického kroužku“ (Kółko Historyczne) - vztah mezi studenty a profesory označoval za ještě bližší než v Praze. Smolka v akademickém roce 1892/1893 přednášel o starších dějinách Polska a polsko-litevské unie a v semináři porovnával Kadłubkovu kroniku s jinými prameny. Zakrzewski přednášel o francouzské revoluci a napoleonských válkách, během seminárních cvičení rozebíral se studenty jejich referáty o zadaných knihách k polským dějinám 16. století. Bidlo hodnotil výše Smolku a jeho metodu výuky srovnával s Gollem (s odkazem na stejné školení u G. Waitze). Průběžně se setkával také s Lucjanem Malinowským, a to jak během přednášek, tak v soukromí. $Z$ dalších přednášejících měl možnost poznat osobně například literárního historika Stanisława Tarnowského nebo historiky Franciszka Piekosińského, Anatola Lewického a Stanisława Krzyżanowského. Velmi oceňoval také snadný př́stup k literatuře, protože disponoval vlastním klíčem od místností historického semináře a mohl bez větších omezení využívat jeho knihovnu. ${ }^{64}$

výzkumu založeného na biografické př́ručce Corpus studiosorum Universitatis Iagellonicae, t. I-VIII, Kraków 1999-2015.

61 Malinowského dopisy Gollovi vydala S. Socнаска (ed.), Listy Lucjana Malinowskiego do Jarosława Golla, 1. c. Dopisy Golla Malinowskému bohužel nejsou patrně dochovány.

62 M. ĎURČANSKÝ, Szkoła historyczna Golla, s. 242n.

63 AUK, FF UK, kart. 1, i. č. 10, protokol ze zasedání profesorského sboru FF UK-F, 14. 7. 1892.

64 Podrobně s odkazy na prameny M. ĎuRČAnskÝ, Krakovský pobyt Jaroslava Bidla. Srov. také Bidlovy autobiografické reflexe, které mi během př́pravy uvedeného textu ještě nebyly známy: D. BRÁDLEROVÁ - J. HÁLEK (edd.), Jaroslav Bidlo - Milada Paulová. Střet generací?, s. 36-40, 52-54, 82-88. 
V Krakově chtěl Bidlo původně strávit jen jeden semestr, hlavním důvodem prodloužení jeho studijního pobytu bylo nalezení tématu disertační práce. Jednalo se o postavu kamaldolského mnicha Jana Jeronýma, který na konci 14. století pobýval rovněž v Krakově. Téma rovněž úzce souviselo s problematikou znovuzaložení krakovské univerzity $\mathrm{v}$ roce $1400 \mathrm{a}$ jejích vztahů $\mathrm{k}$ univerzitě pražské. ${ }^{65}$ Bidlo $\mathrm{k}$ práci kromě rukopisů Jagellonské knihovny využil také knihovnu kamaldolského kláštera v nedalekých Bielanech, kam mu vyjednal př́istup krakovský historik s moravskými kořeny Feliks Koneczny. Právě osobní kontakty byly dalším ziskem Bidlova krakovského pobytu - vedle Koneczného zůstal v trvalém kontaktu se svým kolegou ze Smolkova semináře, pozdějším profesorem Jagellonské univerzity Wacławem Sobieským. Pro ředitele historického semináře české univerzity znamenala bezprostřední zkušenost jednoho ze studentů s analogickým krakovským pracovištěm významné srovnání a dodala jim argumenty při vyjednávání lepších materiálních podmínek (vybavení nábytkem, místo honorovaného asistenta). Bidlo patrně př́liš nepřeháněl, když si připisoval jisté zásluhy v tomto směru. ${ }^{66}$

Bidlův studijní pobyt na Jagellonské univerzitě sice nebyl v rámci jeho oboru právě běžný, v celkovém kontextu obou pražských univerzit ale zase tak výjimečný nebyl. Jeho druhá studijní cesta měla ještě exotičtější charakter. Studentů či budoucích docentů jakéhokoli oboru, kteří odjeli na studijní pobyt do Ruska, bylo opravdu málo. Tady byl Bidlo společně s Čeňkem Zíbrtem (pobyt v Petrohradu v roce 1890) mezi českými historiky skutečnou výjimkou, protože sem směřovali hlavně literární vědci a etnografove. ${ }^{67} \mathrm{~V}$ př́ípadě Bidlova pobytu v Moskvě a Petrohradu už šlo o cílenou př́ípravu k akademické dráze s výhledem na budoucí habilitaci. Jedním z ústředních bodů jeho odborného zájmu i přednášek mělo být právě Rusko a jeho dějiny. Žádost o podporu přednesl profesorskému sboru filozofické fakulty Jaroslav Goll 17. prosince 1896. Pro Bidla mělo být požadováno stipendium ve výši 1000 zlatých a dovolená z jeho povinností suplenta na malostranské reálce pro školní rok 1897/1898. I tentokrát byl návrh jednohlasně přijat. ${ }^{68}$ Hned na počátku Bidlova pobytu v Moskvě Goll doporučil podpořit prodloužení stipendia na letní semestr, což rovněž nenarazilo na žádný odpor - ani ze strany profesorského sboru, ani ze strany místodržitelství. ${ }^{69}$

Do Moskvy přijel Bidlo na konci záŕí 1897. Byl vybaven řadou doporučení, bez nichž se v ruském univerzitním prostředí cizinec neobešel. Nejpř́nosnější po stránce navázání kontaktů pro něj byly styky s historikem Vasilijem Osipovičem Ključevským, s nímž domlouval také výměnu publikací za Český časopis historický. Z vyslechnutých přednášek hodnotil jako pro sebe nejpřínosnější výklady lingvistů Petra Alexejeviče Lavrova, Romana Fedoroviče Brandta a historiků Matveje Kuzmiče Ljubavského, Pavla Gavriloviče Vinogradova a Eugena Ščepkina. V Petrohradě, kam se přesunul počátkem ledna 1898, byl pro něj ústřední postavou „zapadnik“ Nikolaj Pavlovič Karějev. Více než přednášek si ovšem cenil osobních kontaktů s ruskými vědci, zejména při setkáních v domácnostech historika

65 Srov. upravenou verzi disertace vydanou tiskem: J. BidLo, Čeští emigranti v Polsku v době husitské a mnich Jeroným Pražský, ČČM 69, 1895, s. 118-128, 232-265, 424-452. K tématu nově Jan STeJSKAL, Podivuhodný př́běh Jana Jeronýma, Praha 2004.

66 D. Brádlerová - J. HÁlek (edd.), Jaroslav Bidlo - Milada Paulová. Střet generací?, s. 88; M. ĎurČAnSKÝ (ed.), Jaroslav Bidlo: Moje styky s Gollem, s. 16n.

67 K. BLÁHová, České dějepisectví v dialogu s Evropou, s. 63-68.

68 AUK, FF UK, kart. 1, i. č. 15, protokol ze zasedání profesorského sboru FF UK-F, 17. 12. 1896.

69 AUK, FF UK, kart. 1, i. č. 16, protokoly ze zasedání profesorského sboru FF UK-F, 13. 10. 1897 (podpora návrhu v profesorském sboru) a 3.3. 1898 (informace o schválení návrhu místodržitelstvím). 
Sergeje Fjodoroviče Platonova a nestora ruských slavistů Vladimíra Ivanoviče Lamanského. U něj se také seznámil se svým pozdějším kolegou Nikolajem Vladimirovičem Jastrebovem a srbským historikem Stanoje Stanojevićem. Z Petrohradu se Bidlo přes Vilno přesunul do Varšavy, kde ještě pracoval na svém habilitačním spisu o Jednotě bratrské. Po vydání jej připsal profesorovi (ruskojazyčné) varšavské univerzity Nikolaji Nikolajeviči Ljubovičovi, s nímž se ve Varšavě vedle polských historiků také stýkal a vděčil mu za usnadnění přístupu do univerzitní knihovny. ${ }^{70}$

Studijní pobyt v Rusku byl nepochybně jednou z Bidlových mezních životních zkušeností a je naprosto pochopitelné, že své vlastní zážitky dával do kontrastu s námitkami oponentů bez osobní zkušenosti: „Rusko je ohromný předmět studia. Sami Rusové se priznávají, že mu nerozumějí - v tom je jedna z přčcin, proč vláda nebývá ve svých pokusech štastna. Pro člověka, který přijel ničeho té věci nevěda, je poznání Ruska za roky holou nemožnosti. Proto vrátím-li se jako takový člověk, který ví, že nic neví, nebo zná, co by mél jednou vědět - budu pro persona spokojen; nad tím, co si jiní budou o mnè myslet, budu muset jen pokrčit rameny - nebot' já jsem v Rusku byl, a kdo v Rusku nebyl, ten at’o tom mlčí. Je-li kdy autopsie nezbytná, je to právě v Rusku."71 Nabyté zkušenosti byly ovšem vykoupeny onemocněním, které Bidla během části pobytu v Rusku zcela vyřadilo z činnosti, a vedle toho zhoršením vztahů mezi první generací Gollových žáků (srov. níže), jež nepochybně ovlivnila Bidlova dlouhá nepř́ítomnost v Praze. ${ }^{72}$

\section{Akademická kariéra}

K podání žádosti o habilitaci byl Jaroslav Bidlo pobídnut Gollem, který jej předtím také nasměroval ke studiu dějin Jednoty bratrské v polském vyhnanství po roce 1547. Mohl tak př́mo navázat na odborný zájem svého učitele (Goll se zabýval dějinami Jednoty v 15. století) a využít své jazykové vybavenosti i kontaktů v polském prostředí - již během letních měsíců roku 1896 podnikl cestu za př́íslušnými prameny do Poznaně, Lešna a Ochranova, kam se vracel i později. ${ }^{73}$ Jako habilitační práci tak mohl předložit monografii Jednota bratrská v prvním vyhnanství 1548-1561 vydanou v nakladatelství Bursík a Kohout v roce 1900 .

Bidlovu žádost o udělení veniae legendi projednával profesorský sbor filozofické fakulty 19. října a 23. listopadu 1899, kdy byl jednoznačně přijat souhlasný závěr komise vedené J. Gollem (dalšími členy byli historik Josef Kalousek a profesor slovanské filologie František Pastrnek). Posudek napsal Goll, který Bidlovu monografii ocenil po stránce heuristiky a vyzdvihl její mezinárodní význam, což bylo důležité pro habilitaci v oboru všeobecných

70 K Bidlově studijní cestě v letech 1897-1898 srov. B. JIROUŠEK, Cesta Jaroslava Bidla na Rus; Marek FAPŠo, Zahranični studijní pobyty 1. generace Gollovy školy, bakalářská práce na FF UK v Praze, Praha 2010, s. 23-25; D. BrÁdlerová - J. HÁleK (edd.), Jaroslav Bidlo - Milada Paulová. Střet generací?, s. 55-57, 101-105. K osobnosti N. P. Karějeva a jeho významu pro české prostředí průkopnicky Dagmar BlüMLovÁ, Nikolaj Ivanovič Karějev a jeho myšlení o dějinách, in: táž (ed.), Čeněk Zíbrt a kulturní historie. Studie a materiály, České Budějovice 2003, s. 253-271.

71 MÚA AV ČR, fond V. Novotný, kart. 8, i. č. 140, J. Bidlo V. Novotnému.

72 K obojímu tématu vedle výše uvedených autobiografických textů také M. ĎurČAnskÝ, Jaroslav Bidlo a Gollova škola, s. 442n.

73 M. ĎurČAnSKÝ, Jaroslav Bidlo a jeho cesty do Polska, s. 145-149. 
dějin. V podobném duchu hodnotil také Bidlovy starší práce, zejména studii o mnichu Jeronýmovi. Profesorský sbor shledal 17. prosince jako uspokojující také Bidlovo habilitační kolokvium a doporučil, aby se mu ,odpustila veřejná přednáška“. 74

Ministr kultu a vyučování Wilhelm von Hartel potvrdil Bidlovo veniam legendi 3. března $1900 .{ }^{75}$ Již o rok později žádal Bidlo o dovolenou od 15. dubna do 15. července 1901 z důvodu své zhoršující se nemoci (označované jako neurastenie a spočívající v nespavosti kombinované s bolestmi hlavy a zažívacími potížemi). Jeho ošetrujuícím lékařem byl docent Ladislav Haškovec, který mu doporučil úplný odpočinek od duševní námahy v nějakém sanatoriu mimo Prahu. Ministerstvo Bidlovi dovolenou opravdu udělilo, takže mohl na přelomu jara a léta 1901 strávit deset týdnů ve vodoléčebném sanatoriu dr. Jana Mosera v Jincích u Př́brami. ${ }^{76}$

S titulem soukromého docenta byl Bidlo samozřejmě pořád závislý především na příjmu ze své středoškolské výuky a snažil se i v tomto směru využít stávajících možností. Ministerstvo kultu a vyučování vyhovělo 20. listopadu 1902 jeho žádosti, udělilo mu středoškolský titul c. k. profesora a potvrdilo mu místo učitele na Státní průmyslové škole v Praze. ${ }^{77}$ Mohl přitom využít několika mimořádných dovolených pro výzkum v zahraničních archivech, aby dokončil druhý díl práce o Jednotě bratrské v polském exilu. ${ }^{78}$

V roce 1903 vydal Bidlo druhý svazek svého životního díla o Jednotě bratrské. Vzhledem $\mathrm{k}$ bohaté publikační činnosti a pedagogické práci pomýšleli jeho př́znivci na další posun v jeho akademické kariéře. Návrh J. Golla a J. Kalouska na jmenování Bidla mimořádným profesorem byl přednesen profesorskému sboru filozofické fakulty 29. října 1903; př́islušnou komisi doplnil vedle obou uvedených historiků opět František Pastrnek. ${ }^{79}$ Hned na následujícím zasedání byl návrh jednohlasně přijat s doporučením ,přihližeti v přednáškách obzvláště k dějinám východni Evropy a poloostrova Balkánského". ${ }^{80}$ Bidla podle názoru komise obzvláště kvalifikovala také důležitá studie o Karlu Krumbacherovi a byzantologii jakožto oboru velmi důležitému pro slovanské dějiny. Návrh tak už směřoval ke vzdálenějšímu cíli - získání řádné profesury slovanských dějin, o niž fakulta přišla odchodem Konstantina Jirečka. Ministr kultu a vyučování Friedrich von Hartel sice uznal Bidlovy odborné schopnosti, z finančních důvodů ale doporučil pouze udělení titulární mimořádné profesury. Tím mu sice vznikal jistý úvazek na fakultě, nezbavovalo jej to ale paralelního tíživého břemene středoškolské výuky. ${ }^{81}$

74 AUK, FF UK, kart. 1, i. č. 18, protokoly ze zasedání profesorského sboru FF UK-F, 19. 10., 23. 11. a 14. 12. 1899; tamtéž, kart. 10, i. č. 102, osobní spis J. Bidla (zde je uložen originál posudku); K. KazBunda, Stolice dějin, III, s. 223n.

75 Dobový opis dokumentu v MÚA, fond J. Bidlo, kart. 1, i. č. 1.

76 Srov. žádost J. Bidla o dovolenou z 2. dubna 1901, Praha, a žádost téhož o finanční příspěvek na proběhnuvší léčení z 2. prosince 1901, Praha, obojí se souvisejícími lékařskými potvrzeními a doklady. MÚA, fond J. Bidlo, kart. 1 , i. č. 1 .

77 Ředitelství c. k. Státní průmyslové školy v Praze J. Bidlovi, 13. prosince 1902, Praha. MÚA, fond J. Bidlo, kart. 1 , i. č. 1 .

78 Nedatovaný koncept žádosti o dovolenou ke studiu ve varšavských knihovnách v termínu 16. až 30. září 1902; svolení pražského místodržitelství, aby mohl J. Bidlo využít zbývající část školního roku 1902/1903 pro badatelské cesty, pokud ze svého platu zajistí suplování svých předmětů, 10. března 1903. MÚA, fond J. Bidlo, kart. 1 , i. č. 1.

79 AUK, FF UK, kart. 2, i. č. 22, protokol ze zasedání profesorského sboru FF UK-F, 29. 10. 1903.

80 Tamtéž, 14. 1. 1904.

81 K. Kazbunda, Stolice dějin, III, s. 239nn. 
Jmenování titulárním mimořádným profesorem potvrdil císař František Josef I. dne 9. října 1904. V oznámení, které Bidlovi bylo doručeno z ministerstva, byl obsažen také závazek výuky na univerzitě v rozsahu tří až čtyř hodin týdně. Zároveň mu byl přiznán roční plat 2000 zlatých splatný ve dvou termínech. ${ }^{82}$ Profesorský sbor vzal jmenovací dekret na vědomí, přičemž Goll naléhal, aby byla děkanem filozofické fakulty doporučena Bidlova žádost o udělení dovolené ze středoškolské výuky a aby byly hledány cesty k dosažení mimořádné profesury nikoli jen titulární. ${ }^{83}$ Záhy nato (3. listopadu 1904) byl jmenován také členem $c$. k. české zkušebni komise pro učitelství na gymnasiích a reálkách a na školách obchodnich ${ }^{84}$ Zůstala mu ovšem povinnost výuky na průmyslové škole v rozsahu jedenácti hodin týdně s povinností zajištění př́ípadné suplentury z vlastních prostředků. ${ }^{85}$

Na konci akademického roku 1904/1905 byl hotov návrh komise „na jmenování titulárního mimořádného prof. Dra Jaroslava Bidla profesorem mimořádným" a schválen bez připomínek profesorským sborem filozofické fakulty. ${ }^{86} \mathrm{~V}$ odůvodnění formulovaném J. Gollem se kromě vyzdvižení Bidlových odborných kvalit a důležitosti studia dějin slovanských národů a Byzance objevily také argumenty obecnějšího rázu: rapidní nárůst počtu studentů na české univerzitě a odkládaná otázka zrrízení druhé univerzity s českým vyučovacím jazykem. Ministerstvo záležitost vyřizovalo zároveň s mimořádnou profesurou pro Bidlovy souputníky V. Novotného a J. Šustu. V první fázi ale tentokrát uspěl pouze návrh týkající se Bidla, oba dva další byly z finančních důvodů odsunuty. ${ }^{87}$ Císařským výnosem ze dne 8. října 1905 (s platností od 1. dubna 1906) pak byl Bidlo jmenován mimořádným profesorem všeobecných dějin se zvláštním zřetelem k dějinám východní Evropy a balkánských zemí. Jednalo se o systemizované místo s platem ve výši 3600 korun a tzv. aktivním př́idavkem 840 korun. Učební povinnosti zahrnovaly pět hodin přednášek týdně. Příslušnou prŕsahu složil Bidlo místodržiteli hraběti Coudenhove 4. dubna 1906. ${ }^{88}$ Tím skončilo i jeho působení na průmyslové škole, jejíž ředitel Eduard Černý mu vydal př́islušný posudek s pozitivním hodnocením. ${ }^{89}$ Jako nově jmenovaný mimořádný profesor byl Jaroslav Bidlo uvítán na zasedání profesorského sboru filozofické fakulty 3. května 1906 společně

82 MÚA, fond J. Bidlo, kart. 1, i. č. 1, ministr kultu a vyučování J. Bidlovi; místodržitelství J. Bidlovi, 14. listopadu 1904, Praha (opis).

83 „Čten [... dekret] o udělení titulu mimořádného profesora dru Bidlovi s určitým př́kazem čísti tři až čtyři hodiny týdně o ,dějinách východní Evropy a Balkánu‘. P. prof. Goll upozorňuje, že bude prof. Bidlo žádati za dovolenou i navrhuje, aby sbor zmocnil děkana, by žádost tu co nejlépe doporučil. Dále aby opis jmenovacího dekretu byl dán komisi (referent prof. Goll), jež své doby dra Bidla navrhla, kteráž by uvážila, co se má v příčině profesury původně navržené státi. Přijato jednomyslně.“AUK, FF UK, kart. 2, i. č. 23, protokol ze zasedání profesorského sboru FF UK-F, 27. 10. 1904.

84 MÚA, fond J. Bidlo, kart. 1, i. č. 1, ředitel c. k. české zkušební komise Čeněk Strouhal J. Bidlovi, 8. listopadu 1904, Praha.

85 MÚA, fond J. Bidlo, kart. 1, i. č. 1, místodržitelství J. Bidlovi, 4. prosince 1904, Praha.

86 AUK, FF UK, kart. 2, i. č. 23, protokol ze zasedání profesorského sboru FF UK-F, 21. 6. 1905. V souvislosti s podobnými př́pady Goll záhy prosadil do jednacího řádu profesorského sboru FF ustanovení, díky němuž mohly komise ke jmenování řádných i mimořádných profesorů podávat návrhy v př́slušné věci do té doby, dokud nedojde k „úplnému vyřízení prvotních návrhư“. Tamtéž, 28. 6. 1905.

87 K. KazBunda, Stolice dějin, III, s. 276-281; odůvodnění komise v př̌kladu do němčiny je uloženo v AUK, fond FF UK, kart. 10, i. č. 102, osobní spis J. Bidla.

88 MÚA, fond J. Bidlo, kart. 1, i. č. 1, přípis ministerstva kultu a vyučování, 10. října 1905, Vídeň.

89 „Pan profesor Dr. Jaroslav Bidlo konal veškeré své povinnosti velmi svědomitě a horlivě a ve př́icině povahy i mravní zachovalosti byla pověst jeho vždy beze vší úhony.“ Viz MÚA, fond J. Bidlo, kart. 1, i. č. 1, vysvědčení o ,službě učitelské“ na c. k. Státní průmyslové škole v Praze, 3. dubna 1906. 
s Josefem Šustou..$^{90}$ Od té doby se účastnil těchto jednání pravidelně, pokud mu v tom nebránily jiné povinnosti nebo nemoc.

Služební postup přišel pro Bidla právě včas, protože se 30. září 1905 oženil. Jeho žena Marie, rozená Dvořáčková (narozena 18. 2. 1883) byla dcerou učitele kolínské zemědělsko-řemeslné školy Josefa Dvořáčka a jeho ženy Barbory, rozené Kyselové. ${ }^{91}$ Manželům Bidlovým se 16. ř́jina 1906 narodila dcera Vladimíra ${ }^{92}$ a 10. července 1908 syn Jaroslav. ${ }^{93}$

Návrh na jmenování řádným profesorem předložili profesorskému sboru filozofické fakulty 6. června 1909 J. Goll, L. Niederle a J. Pekař zároveň s návrhem na jmenování Josefa Šusty. ${ }^{94}$ Odůvodnění datované 11 . rríjna 1909 bylo opět formulováno Gollem. Kromě nejnovějších Bidlových vědeckých prací (zejména třetího dílu Dějin Jednoty bratské) poukazoval Goll na důležitost studia dějin Slovanů a východní Evropy, a to i na neslovanských univerzitách (Berlín), respektive na nejdůležitější univerzitě habsburské monarchie (Vídeň a seminář K. Jirečka). ${ }^{95}$ Neopomněl opět zmínit také problematiku byzantských dějin. Reakce profesorského sboru filozofické fakulty byla jednomyslně pozitivní, a poté byl návrh v písemné formě vřele doporučen Josefem Pekařem, tehdy děkanem fakulty. Ani v tomto případě ale nebyl ministerstvem obratem schválen. Za poukazováním na důvody finančního rázu v Bidlově případě tentokrát patrně stála i jistá nechut' ke (znovu)zř́zení stolice slovanských dějin v době stupňujícího se konfliktu se Srbskem a hrozící války s Ruskem. ${ }^{96}$

Situaci vyřešil Gollův odchod do penze - Bidlo byl jmenován jakožto starší přímo na systemizovanou uvolněnou stolici, zatímco Šusta pouze „,ad personam“ po Gollově intervenci na ministerstvu financí. Nedošlo tak k obnovení systemizované stolice pro dějiny Slovanstva a východní Evropy (uprázdněné odchodem K. Jirečka), jak si Goll původně představoval. Proto tedy alespoň naléhal na to, aby byla rychle obsazena Bidlem uprázdněná mimořádná profesura, konkrétně Kamilem Kroftou. ${ }^{97} \mathrm{Na}$ Štědrý den roku 1910 (s účinností od 1. ledna 1911) byl Jaroslav Bidlo jmenován řádným profesorem obecných dějin se zvláštním zřetelem k dějinám východní Evropy a balkánských zemí (,mit besonderer Berücksichtigung der Geschichte Ost-Europas und der Balkanländer"). $\mathrm{K}$ povinnostem mu přibylo vypsat minimálně v každém třetím semestru také jednu veřejnou přednášku, tzv. publicum, $\mathrm{k}$ některému $\mathrm{z}$ dílčích témat $\mathrm{v}$ rámci oboru. Roční plat měl činit 6400 korun s aktivním přídavkem 1472 korun. ${ }^{98}$ Tím dosáhl de facto vrcholu

90 Bidlo byl tehdy poprvé také zapisovatelem protokolu ze schůze (profesoři se v této službě stř́idali). AUK, FF UK, kart. 2, i. č. 24, protokol ze zasedání profesorského sboru FF UK-F, 3. 5. 1906.

91 MÚA, fond J. Bidlo, kart. 1, i. č. 1, oddací list z 10. října 1905 vydaný Farním úřadem u svaté Ludmily na Královských Vinohradech.

92 Srov. př́pis Zemské správy politické J. Bidlovi, 10. listopadu 1924, Praha (týká se plnoletosti V. Bidlové a souvisejících finančních záležitostí), MÚA, fond J. Bidlo, kart. 1, i. č. 1.

93 Srov. př́ípis Zemské správy politické J. Bidlovi, 15. října 1926, Praha (týká se plnoletosti J. Bidla ml. a souvisejících finančních záležitostí; opis), MÚA, fond J. Bidlo, kart. 1, i. č. 1.

94 AUK, FF UK, kart. 2, i. č. 27, protokol ze zasedání profesorského sboru FF UK-F, 17. 6. 1909. Návrh komise znovu jednomyslně přijat 28. ř́ína 1909. Tamtéž, i. č. 28, protokol ze zasedání profesorského sboru FF UK-F, 28. 10. 1909.

95 K problematice vývoje historických oborů na uvedených univerzitách srov. monografii Pavel KolÁŘ, Geschichtswissenschaft in Zentraleuropa. Die Universitäten Prag, Wien und Berlin um 1900, I-II, Berlin 2008.

96 K. Kazbunda, Stolice dějin, III, s. 290-293.

97 Tamtéž, s. 387-389, 402-404.

98 Výnos ministra kultu a vyučování, 30. prosince 1910, Vídeň. Za podpisem ministra Stürgkha následuje rukopisná poznámka: „Byl panem c. k. místodržitelským vice-praesidentem Jindřichem Vojáčkem na složení 
možného služebního postupu. O jeho působení v rámci akademické samosprávy pojednávám níže; vrchol jeho veřejné a organizační činnosti měl přijít po vzniku Československa, odehrával se ale do jisté míry ve vědeckých společnostech mimo univerzitu (Slovanský ústav, Česká akademie věd a umění, Královská česká společnost nauk, Československá národní rada badatelská). ${ }^{99}$

\section{Přednášky}

Jádrem Bidlova působení na fakultě byla samozřejmě přednášková činnost a praktická výuka $\mathrm{v}$ historickém semináři. Seznam jeho ohlášených přednášek sestavený na základě tišsěných seznamů („,Karolinek“) připojuji níže. Je na něm v souvislosti s vývojem Bidlových badatelských zájmů vidět několik trendů, které jsou ostatně ze starších biografických a autobiografických textů částečně již v hrubých obrysech známy. ${ }^{100}$ Obsahové stránce přednášek, která si ještě vyžádá podrobnější analýzu podkladů dochovaných v osobním fondu, bude věnována pozornost $\mathrm{v}$ samostatném textu. Na tomto místě se omezuji na stručný přehled.

První přednášky vycházely z dosavadní znalosti polské a ruské historiografie a reflektovaly také vzájemné polsko-ruské vztahy v raném novověku (reálně jich část, jak již bylo naznačeno výše, kvůli Bidlově nervové chorobě odpadla). Po seznámení se s životním dílem mnichovského byzantologa Karla Krumbachera věnoval Bidlo několik semestrů byzantským dějinám a Balkánu. Na revoluční události v Rusku v roce 1905 a oživený zájem o evropský Východ reagoval dvěma semestry přednášek, z nichž vzešla také populární monografie Dějiny Ruska v 19. století (vydáno 1907-1908); výklady na téma Přehledné dějiny slovanských národů zase souvisely s novoslovanským hnutím a připravovanou kolektivní monografií Slovanstvo (1912). ${ }^{101}$ Do roku 1914 se pak mezi tématy velmi často objevují dějiny Balkánu, které byly vzhledem k anexi Bosny a Hercegoviny tématem výsostně aktuálním. Podobně frekventované byly také přednášky týkající se polsko-ruských vztahů v raném novověku, které souvisely především s prací na dalších dílech Dějin Jednoty bratrské v polském vyhnanství, i tak ale mohlo být téma vnímáno do jisté míry jako aktuální (polsko-ruský spor byl považován za hlavní překážku v dorozumění mezi slovanskými národy).

Mezi lety 1915-1921 přednášel Bidlo dlouhý cyklus Dějiny evropského východu ve středověku a znovu se $\mathrm{k}$ němu vrátil v roce 1931. I v meziválečném období můžeme nalézt některé přednášky zjevně ovlivněné jeho momentálními odbornými zájmy. Je to jednak Literatura k dějinám evropského východu $\mathrm{v}$ roce 1922-1923 (tedy v době, kdy se intenzivně zabýval akvizicí slavistické literatury nejen pro Univerzitu Karlovu), dějiny polsko-litevského soustátí na přelomu 20. a 30. let (čtvrtý díl Jednoty bratrské a související studie)

přísahy upomenut dne 7. ledna 1911."O remuneraci oznámení děkanátu filozofické fakulty J. Bidlovi, 27. listopadu 1911, Praha. Oba dokumenty uloženy v MÚA, fond J. Bidlo, kart. 1, i. č. 1. K platům univerzitních profesorů v habsburské monarchii a v Německu kolem roku 1900 Jan SuRman, Universities in Austria 1848-1918. A Social History of a Multilingual Space, West Lafayette 2019, zvl. tabulka na s. 170.

99 Této problematice bude brzy věnována samostatná studie.

100 D. BRÁdLerovÁ - J. HÁleK (edd.), Jaroslav Bidlo - Milada Paulová. Střet generací?, s. 62-66.

101 O Bidlovi a novoslovanství podrobněji Marek ĎuRČANskÝ, Czeski historyk Jaroslav Bidlo i jego udziat w ruchu nowosłowiańskim przed I Wojną Światowa (v tisku - Práce Historyczne. Zeszyty Uniwersytetu Jagiellońskiego). 
a v posledních letech života Východoevropské dějepisectví, související nepochybně s jeho účastí v diskuzích o charakteru východoevropských dějin a organizačními aktivitami v rámci Federace historických společností východní Evropy.

Také v meziválečném období některé již ohlášené přednášky odpadaly. Studenty a mladšími kolegy byl $\mathrm{v}$ té době Bidlo již vnímán jako člověk nepř́liš pevného zdraví102 a sám také poměrně často žádal o dovolenou nebo alespoň částečné úlevy z výuky. Nebylo to ovšem vždy jen kvůli zdravotnímu stavu, v některých př́ípadech se jednalo o snahu dokončit některou z větších prací, př́padně jiné mimořádné povinnosti. Pro školní rok 1919/1920 si tak Bidlo, přetížený organizačními úkoly v oblasti vědeckého a kulturního života nového státu, ${ }^{103}$ požádal u ministerstva o dovolenou. Bylo mu umožněno pouze snížení pedagogických povinností. Argumentace ministerstva je ve vztahu k oboru historické slavistiky natolik zajímavá, že si zaslouží obsáhlejší citaci: „Ministerstvo školství a národní osvěty, jakkoli plně uznává závažnost důvodi̊, jimiž rádný profesor dějin všeobecných Dr. Jaroslav Bidlo podporuje svou žádost za dovolenou v školním roce 1919/20, nemůže nedbati toho, že by v prvém rozvrhu učebním jediné dosud české fakulty filosofické, sestavovaném za naši státni samostatnosti, obor slavistický, jenž změnou politických poměrů nabyl pro nás tak velikého významu, byl ochuzen mérou velmi povážlivou, kdyby prof. Bidlo viobec neprednášel. Proto vyhovuje jeho žádosti jen potud, že snižuje jeho učebni povinnost ve školním roce 1919/20 z pěti týdennich hodin na dvě (krom cvičení seminárnich) a očekává, že prof. Bidlo, maje na mysli zájem našeho státu o nejrozsáhlejšsi a nejdůkladnějši pěstováni studii slavistických na našich vysokých školách, spokojí se s touto úlevou."104

V dalších letech využil možnosti úlev od pedagogických povinností ještě několikrát. Č́stečnou dovolenou od přednášek vzhledem „ke speciálním vědeckým pracím“získal také v následujícím roce 1920/1921, kdy měl místo povinných pěti hodin přednášet tři hodiny týdně, ${ }^{105}$ plnou dovolenou ,za účelem dokončení vědeckých praci" $\mathrm{v}$ akademickém roce $1924 / 1925^{106}$ a podobně 1928/1929, , ,aby mohl dokončiti započaté védecké práce“. ${ }^{107}$ Kratší studijní dovolenou (3. listopadu - 6. prosince 1930) ${ }^{108}$ mu ministerstvo udělilo i v následujícím roce. Ta byla nepochybně odůvodněna badatelskou cestou do Krakova a Varšavy. ${ }^{109}$ Za většinou uvedených úlev můžeme vidět konkrétní publikace, s jejichž př́ípravou bylo spojeno zvýšené úsilí - v roce 1923 vyšel druhý svazek velké edice Akty Jednoty bratrské, v roce 1928 Dějiny Slovanstva a v roce 1932 čtvrtý díl Jednoty bratské v polském vyhnanství. Další úlevy už byly spojeny spíše s projevy stárnutí a zhoršujícím se zdravotním stavem, byt' zněl oficiální důvod trochu jinak. V akademickém roce 1932/1933 povolilo ministerstvo Bidlovi na jednomyslnou žádost profesorského sboru filozofické fakulty snížení

102 B. Jiroušek, O vzpomínkách Josefa Klika, s. 136-138; M. Seкrrková (ed.), Otakar Odložilik: Deniky z let 1924-1948, I, passim.

103 Srov. M. ĎuRČAnSKÝ, Jaroslav Bidlo jako osoba veřejná, s. 61-64.

104 MÚA, fond J. Bidlo, kart. 1, i. č. 1, Ministerstvo školství a národní osvěty (dále jen MŠANO) děkanátu FF UK, 5. června 1919, Praha (opis).

105 Tamtéž, MŠANO děkanátu FF UK, 15. května 1920, Praha (opis).

106 Tamtéž, MŠANO děkanátu FF UK, 12. června 1924, Praha (opis). Srov. také AUK, FF UK, kart. 3, i. č. 42, protokol ze zasedání profesorského sboru FF UK, 15. 5. 1924, schválení návrhu ze strany profesorského sboru.

107 MÚA, fond J. Bidlo, kart. 1, i. č. 1, MŠANO děkanátu FF UK, 24. května 1928, Praha (opis). Srov. také AUK, FF UK, kart. 4, i. č. 46, protokol ze zasedání profesorského sboru FF UK, 3. 5. 1928, schválení návrhu ze strany profesorského sboru.

108 MÚA, fond J. Bidlo, kart. 1, i. č. 1, MŠANO děkanátu FF UK, 12. listopadu 1930, Praha (opis).

109 M. ĎurČAnSKÝ, Jaroslav Bidlo a jeho cesty do Polska, s. 149. 
počtu vyučovacích hodin na dvě týdně, ${ }^{110} \mathrm{v}$ následujícím roce na tři hodiny týdně, ${ }^{111}$ a stejně tak v roce 1935/1936 (s oficiálním odůvodněním , $k$ umožnění literární práce vědecké“), ${ }^{112}$ 1936/1937 (bez bližšího zdůvodnění) ${ }^{113}$ a 1937/1938 (,,k umožnění dalši vědecké práce literární a badatelskéc $)^{114}$. Tehdy už byl ale jeho zdravotní stav opravdu povážlivý. Bidlo reálně vůbec nepřednášel a jeho povinnosti v historickém semináři převzala s vědomím profesorského sboru Milada Paulová. Ministerstvo mu schválilo dovolenou ze zdravotních důvodů na zimní semestr 1937/1938, v jehož průběhu zemřel. ${ }^{115}$ Jeho pohřbu, který se konal 4. prosince z kostela sv. Václava na Vinohradském hřbitově, se měli podle běžného úzu účastnit všichni členové akademického senátu Univerzity Karlovy. ${ }^{116}$ Fakulta poté vyhověla návrhu prezidia Slovanského ústavu na uspořádání společné tryzny. ${ }^{117}$

\section{Historický semináŕ}

Historický seminář byl před postavením nové budovy filozofické fakulty umístěn ve 2. patře Klementina a během dlouhého působení Bidla a jeho kolegů sestával ze tří místností: studovny vybavené stoly a př́ruční knihovnou, společné pracovny Bidla a Šusty a samostatné pracovny Pekaře jakožto ředitele semináře. Novotný měl pracovnu v nižším patře. ${ }^{118}$

V seznamech přednášek ${ }^{119}$ se Jaroslav Bidlo v souvislosti s historickým seminářem poprvé objevuje v Gollově zastoupení v semestru 1907/1908 (Goll byl v tomto akademickém roce rektorem), ${ }^{120} \mathrm{kdy}$ vedl písemné práce a podával výklad pramenů. Návrh na jmenování spoluředitelem historického semináře byl jednomyslně podpořen profesorským sborem filozofické fakulty na konci téhož semestru; ${ }^{121}$ ministerstvo kultu a vyučování schválilo návrh na jeho jmenování místo mezitím odstoupivšího Golla dne 8. června 1908.122 Od následujícího akademického roku už tedy působil sám za sebe a byl společně s Josefem Pekařem a Josefem Šustou veden jako ředitel historického semináře. Ironií osudu působil právě tehdy na postu asistenta semináře Bidlův pozdější osobní nepřítel Jan Slavík.

110 MÚA, fond J. Bidlo, kart. 1, i. č. 1, MŠANO děkanátu FF UK, 10. června 1932, Praha (opis).

111 Tamtéž, MŠANO děkanátu FF UK, 28. června 1933, Praha (opis); AUK, FF UK, kart. 5, i. č. 51, protokol ze zasedání profesorského sboru FF UK, 27. 4. 1933, schválení návrhu ze strany profesorského sboru.

112 MÚA, fond J. Bidlo, kart. 1, i. č. 1, MŠANO děkanátu FF UK, 18. července 1935, Praha (opis).

113 Tamtéž, děkan FF UK Miloslav Hýsek J. Bidlovi, 2. července 1936, Praha; AUK, FF UK, kart. 5, i. č. 54, protokol ze zasedání profesorského sboru FF UK, 7. 5. 1936.

114 MÚA, fond J. Bidlo, kart. 1, i. č. 1, děkan FF UK Antonín Salač J. Bidlovi, 14. června 1937, Praha; AUK, FF UK, kart. 6, i. č. 55, protokol ze zasedání profesorského sboru FF UK, 8. 4. 1937.

115 MÚA, fond J. Bidlo, kart. 1, i. č. 1, MŠANO děkanátu FF UK, 4. listopadu 1937, Praha (opis).

116 AUK, fond Akademický senát UK, kart. 16, i. č. 336. V této složce jsou kromě parte a pozvánky k účasti na pohřbu uloženy také kondolence směřované do rukou akademického senátu Univerzity Karlovy, zatímco kondolence adresované fakultě jsou součástí Bidlovy fakultní osobní složky.

117 AUK, fond FF UK, kart. 6, i. č. 56, protokol ze zasedání profesorského sboru FF UK, 27. 1. 1938.

118 D. Brádlerová - J. HÁlek (edd.), Jaroslav Bidlo-Milada Paulová. Střet generací?, s. 135n; J. Hoffmannová, Václav Novotný, s. 173.

119 Není-li uvedeno jinak, jsou příslušné údaje čerpány z tištěných seznamů přednášek.

${ }^{120}$ Návrh profesorského sboru fakulty, aby se Bidlo ujal cvičení v historickém semináři od zimního semestru 1907/1908, schválilo ministerstvo dne 25. května 1907. MÚA, fond J. Bidlo, kart. 1, i. č. 1; AUK, FF UK, kart. 2, i. č. 25, protokol ze zasedání profesorského sboru FF UK-F, 2. 5. 1907.

121 AUK, FF UK, kart. 2, i. č. 26, protokol ze zasedání profesorského sboru FF UK-F, 14. 5. 1908.

122 MÚA, fond J. Bidlo, kart. 1, i. č. 1, místodržitelství děkanátu Filozofické fakulty České Karlo-Ferdinandovy univerzity, 4. července 1908, Praha. 
Po jmenování Bidla spoluředitelem historického semináře byla seminární knihovna dovybavena o důležitá slavica. Pekař v roce 1909 v žádosti o zvýšení dotace argumentoval poukazem na existenci zvláštního semináře $\mathrm{k}$ dějinám východní Evropy na vídeňské univerzitě. Mezitím byl z Pekařova podnětu a za souhlasu obou jeho kolegů historický seminář reorganizován. Zatímco dřive se mohli studenti do semináře zapsat ve třetím ročníku, nově měl seminář zahrnovat celé první tři roky studia s tím, že každý rok jeden z ředitelů začínal propedeutikou se studenty prvního ročníku. Pokračoval s nimi potom i v následujících dvou letech, během nichž byly kriticky rozebírány konkrétní historické prameny a literatura. Tehdy se mohli také zároveň zapsat do semináře dalšího z ředitelů. Vzrůstající počet posluchačů vedl k rozšíření historického semináře a vzniku dalších dvou oddělení. Od letního semestru 1911/1912 se stali spoluřediteli historického semináře také Václav Novotný a Kamil Krofta. Tato personální situace vydržela téměř celou dekádu, než do ní zasáhly okolnosti spojené se vznikem samostatného Československa. ${ }^{123}$

$\mathrm{V}$ prvních popřevratových letech byly personální změny ve vedení historického semináře největší. Kamila Kroftu povolaného do diplomatických služeb v zimním semestru 1919/1920124 nahradil přechodně Vlastimil Kybal, rovněž budoucí diplomat. Hned v následujícím semestru přišel místo Kybala nakrátko Julius Glücklich a šestým z ředitelů historického semináŕe se stal Josef Vítězslav Šimák. ${ }^{125}$ Glücklich záhy odešel na brněnskou Masarykovu univerzitu a také Šimák z „karolinek“ dočasně zmizel, přičemž se místo něj od letního semestru 1920/1921 objevuje ruský historik Nikolaj Jastrebov, který byl jmenován spoluředitelem semináře na Bidlův návrh. ${ }^{126}$ Od zimního semestru 1922/1923 nahradil Jastrebova opět Šimák. Až v roce 1935 se objevují jména zástupců mladší generace Otakara Odložilíka a Bedřicha Mendla. Na podzim 1937 bylo Bidlovo oddělení na jeho vlastní žádost svěřeno Miladě Paulové. 127

$\mathrm{V}$ seznamech přednášek jsou jednotlivé stupně historického semináře označovány různě. Když měl Bidlo na starosti úvod do studia pro začínající studenty, byl např́íklad v zimním semestru 1910/1911 předmět výslovně označován jako , historická propedeutika pro posluchače prvního ročníku“. V seznamech přednášek lze vysledovat také jeho snahu o jisté propojení práce $\mathrm{v}$ semináŕi s přednáškami, konkrétně s úvodem do polských dějin. ${ }^{128}$ Bidlo později přímo uváděl, že se v přípravném oddělení semináře jednou za tři roky snaží „své žáky poněkud připravovati, aby byli trochu zasvěceni do oboru dějin východoevropských“,

123 K. KazBunda, Stolice dějin, III, s. 265-270.

124 Právě počátkem akademického roku 1919/1920 podali ředitelé historického semináře Ministerstvu školství a národní osvěty návrh na zř́zení pěti stipendií pro nadané studenty. Ministerstvo žádost odmítlo s odůvodněním, že právě vzniká „vysoká škola archivářská“ (tedy pozdější Státní archivní škola), kde „zajisté bude možno většině nadaných posluchačů historie, kteří by se chtěli připraviti k samostatnému bádání vědeckému, aby jako členové archivářské školy domohli se hmotné podpory státní“. Př́ímá stipendia členům historického semináře měla být ministerstvem nadále udělována jen v jednotlivých případech a v různé výši. MÚA, fond J. Bidlo, kart. 1, i. č. 1, Ministerstvo školství a národní osvěty děkanátu Filozofické fakulty University Karlovy, 9. září 1919, Praha.

$125 \mathrm{~K}$ Bidlovu podílu na Šimákově profesuře - at' již v dobrém, či ve zlém - srov. H. KÁBovÁ, Josef Vitězslav Šimák, s. 131-134.

${ }^{126}$ Celý Bidlův návrh přijatý profesorským sborem FF UK směřoval k tomu, aby ,prof. Novotný pro veliký počet posluchačů rozdělil svůj seminář a vedl obě oddělení za náležitou remuneraci a aby prof. Jastrebov byl jmenován dalším spoluředitelem historického semináře pro praktický výcvik posluchačů." AUK, FF UK, kart. 3, i. č. 39, protokol ze zasedání profesorského sboru FF UK, 21. 10. 1920.

127 AUK, FF UK, kart. 6, i. č. 56, protokol ze zasedání profesorského sboru FF UK, 15. 10. 1937.

128 V seznamech přednášek je u tohoto předmětu výslovná poznámka: „Doporučuje se zvláště členům prvních oddělení historického semináře.“ 
pobízí je „, studiu jazyki̊ slovanských“ a seznamuje s př́slušnou literaturou. Dodával ještě, že jeho „obor je těžši jiných oborů a neni tak poutavý jako jiné, proto jest o něj zájem mezi

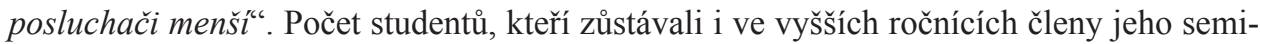
náře, odhadoval zhruba na třetinu. ${ }^{129}$

Prameny, které byly předmětem rozboru ve vyšších ročnících semináře, obvykle souvisely (podobně jako část přednášek) s aktuálními Bidlovými badatelskými zájmy. Tak v roce 1908/1909, když připravoval k tisku třetí svazek Dějin Jednoty bratrské zahrnující roky 1572-1586, rozebíral se studenty prameny k českému zemskému sněmu roku 1575. V následujícím roce, kdy bylo aktuální výročí bitvy u Grünwaldu, byla pozornost zaměřena na př́slušné pasáže $z$ kroniky Jana Długosze a další prameny. ${ }^{130}$ Bidlo tehdy bitvě věnoval několik popularizačních článků. ${ }^{131} \mathrm{~V}$ letech $1911-1915$ převažovaly prameny související s byzantskými dějinami (v roce 1917 vydal Bidlo spis Kultura byzantská a její význam), v roce 1915-1916 se vrátil k problematice polských dějin 16 . století, o dva roky později pak probíral prameny ke vzniku nejstarších slovanských států. $V$ př́pravném oddělení přednášel Bidlo teoretické a metodologické základy historiografie podle Bernheimova spisu Lehrbuch der historischen Methode. ${ }^{132}$

\section{Nejbližší kolegové}

Již během studií na filozofické fakultě poznal Jaroslav Bidlo řadu zajímavých osobností at' už mezi přednášejícími, nebo studenty - $\mathrm{s}$ nimiž měl v budoucnu přicházet opakovaně do kontaktu či př́mo úzce spolupracovat. Vzhledem k oboru, který na univerzitě zastupoval, stály co do důležitosti na prvním místě vztahy $\mathrm{k}$ jeho dlouholetým souputníkům Pekařovi, Šustovi a Novotnému. Na jejich utváření se podílela také proměnlivá vazba k Jaroslavu Gollovi, který Bidla na počátku do značné míry usměrnil v jeho badatelských zájmech a v prvních krocích jeho akademické kariéry. V přátelském duchu se zpočátku nesly i Bidlovy kontakty s „korunním princem“ Josefem Pekařem. Svědčí o tom jejich dochovaná vzájemná korespondence. Jak je vidět z výše uvedeného přehledu Bidlovy akademické kariéry, hlavním hybatelem jednotlivých kroků byl většinou Goll, i když samožrejmě ne vždy se stejnou intenzitou, a nelze také pominout Antonína Rezka nebo Josefa Kalouska.

K významnému zlomu ve vztahu Bidla ke Gollovi a $\mathrm{k}$ Pekařovi došlo během jeho pobytu v Moskvě a Petrohradu v akademickém roce 1897/1898. Jestliže se do té doby někdy cítil izolován a přehlížen, pak v této době se uvedené pocity významně umocnily. Měl dojem, že kolegové neodpovídají na jeho dopisy (o nichž si vzhledem $\mathrm{k}$ nespolehlivosti poštovního spojení z Ruska zároveň nemohl být zcela jistý, že k adresátovi určitě dorazily), zatajují mu informace v kruhu Gollových starších žáků běžně sdílené133 a ignorují prosby týkající se finančních záležitostí (proplacení směnek, honoráře za články), které pro něj byly životně

\footnotetext{
129 D. Brádlerová - J. HÁlek (edd.), Jaroslav Bidlo - Milada Paulová. Střet generací?, s. 66.

130 K. KazBunda, Stolice dějin, III, s. 289.

131 J. BidLo, Grunwald, Česká revue 1909-10, č. 10, s. 577-596; TÝž, Grunwald, Národní listy, č. 181, 3. 7. 1910, s. 9.

132 K. Kazbunda, Stolice dějin, III, s. 391-393.

133 „Loni co již dávno vrabci na střeše zpívali a co v kroužku Gollově všickni věděli, dovídal jsem se já vždycky jako z milosti poslední a letos se vůbec nedovídám ničeho." MÚA AV ČR, fond V. Novotný, kart. 8, i. č. 140, J. Bidlo V. Novotnému, 23. 3. 1898, Petrohrad.
} 
důležité. Doslova jej ranilo zlehčování vážného onemocnění, jež v Rusku prodělal. Vztah s Pekařem se poté víceméně zhoršoval až do definitivní roztržky, v níž hrál svou roli také Goll, na konci roku 1916. Jestliže Bidlo s Gollem k sobě dodatečně ještě jakousi cestu našli, s Pekařem nikoli. ${ }^{134}$

Dlouhodobě napjaté vztahy mezi dvěma řádnými profesory na jednom pracovišti se musely nutně odrazit také v osudech jejich žáků a mladších kolegů. ${ }^{135}$ Bidlo měl (podle všeho zaslouženou) pověst př́ísného zkoušejícího a právě jeho neústupnost i vůči oblíbeným studentům jeho kolegů, byla jedním z kamenů úrazu v jeho vztahu k Pekařovi. Dalším bylo jisté přehlížení jeho oboru, shrnuté Pekařem v roce 1928 lapidárně v souvislosti se zaměřením Českého časopisu historického: „Nezapomínej, že náš Časopis má v programu v prvé řadě české dějiny, v druhé řadě logicky západ evropský, teprve v třetí radě prijde východ slovanský. "136 V uvedeném roce došlo u př́ležitosti Bidlovy šedesátky k pokusu trochu otupit ostří vzájemné animozity, ale zůstalo jen u pokusu. Milada Paulová shrnula vztah obou svých učitelů následovně: ,Ale s Pekařem nebyl styk skoro možný. Prostě se s Bidlem nesnášeli. Ani mluvit spolu nebyli s to. V gestu a mluvě jednoho (Pekaře) pohrdání, u druhého krajni podráždění. Tedy spolu prostě nemluvili, když, tak prostřednictvím Šusty. “137

Korektní vztahy udržoval Bidlo po celou dobu společného působení právě s Josefem Šustou, s nímž nikdy nepřešli k tykání, ${ }^{138}$ ačkoli museli jako ordináři oboru světových dějin - byt' každý s jinou specializací - úzce spolupracovat. Bidlo jistě př́liš nepřeháněl, když v blahopřání k Šustovým šedesátinám psal: „Těši mě, že jsem s Vámi žil tak dlouho v souhlase a míru a př́l bych si, bude-li mi popřáno ještě několik let s Vámi spolupůsobiti, aby náš soulad potrval." 139 Spolu utvořili také autorský tandem produkující úspěšné středoškolské učebnice dějepisu (,Bidlo - Šusta - Hýbl“, respektive „Bidlo - Šusta - Dobiášs"). Šusta svého kolegu přibral do autorského kolektivu melantrišských Dějin lidstva, ačkoli se jeho účastí zkomplikovala spolupráce s mladšími historiky - konkrétně např́iklad s J. Macůrkem, který byl Šustou původně osloven jako potenciální autor kapitoly o polsko-ruských vztazích v letech 1450-1650. Bylo to vedle ohledů kolegiálních asi dáno také pragmatickým př́stupem, jak o tom může svědčit pasáž z dopisu Šusty Václavu

134 Podrobně M. ĎurČAnSKÝ, Jaroslav Bidlo a Gollova škola, s. 446-448.

135 Př́́kladem mohou být dilemata týkající se jubilejních sborníků k šedesátinám obou historiků, v nichž se seznam přispěvatelů překrýval jen velmi málo. Srov. napřr. reakce O. Odložilíka: Milada SEkyrková (ed.), Vzájemná korespondence Václava Novotného, Jaroslava Prokeše a Otakara Odložilikia, Sborník archivních prací 51, 2001, s. 85-274, zde s. 232, 234, 239, 242.

136 MÚA, fond J. Bidlo, kart. 6, i. č. 485, Pekař Bidlovi, 2. 12. 1928, Praha. Bidlo v relativně stručné odpovědi reagoval: „Co se týče ČČH, tedy zde se nesejdeme. Jestliže jsem [v odpovědi] na Tvůj první dopis psal o tom, tedy jsem tím reagoval na Tvou rozmluvu s Paulovou. Poněvadž mi jinak nebylo pochopitelné Tvé jaksi sentimentální přání po sblížení, tedy jsem v něm viděl ono pozadí. Jak moji žáci se dívají na otázku svého spolupracovnictví v ČČCH, to ti Paulová [ře]kla jasně. Macůrek mi osvědčil, že s ní [pl]ně souhlasí a žádal mě, abych Ti [to] řekl, poněvadž jemu je ženantní [!], aby Ti to řekl přímo osobně. Na to vuřtlování slovanské rubriky v ČČH Ti zajisté postačí Hájek a jiní moji žáci, se kterými nemám žádných vyšších záměrů.“A Archiv Národního muzea, fond Josef Pekař, kart. 18, i. č. 458, Bidlo Pekařovi, 4. prosince 1928, Praha. Dopis má utržený okraj, a kvůli tomu scházejí malé fragmenty textu - pravděpodobně byla obálka roztržena s mimořádnou razancí bez použití běžného nože na otevírání obálek.

137 D. BrádLerová - J. HÁlek (edd.), Jaroslav Bidlo - Milada Paulová. Střet generací?, s. 136.

${ }^{138}$ V tomto detailu jsem toho názoru, že při posuzování vztahu Bidlo - Pekař je nutné vzít v úvahu právě zachování tykání i přes vyhrocené vztahy. Myslím, že to svědčí o snaze udržet emoce alespoň trochu v mezích a ulehčit jakýsi křehký modus vivendi.

139 Národní archiv, fond Josef Šusta, kart. 2, i. č. 16, J. Bidlo J. Šustovi, 18. 2. 1934, Praha. 
Chaloupeckému z poloviny 30. let: „Nemohu se obejíti při celku díla bez Bidla a jeho leníkư, a musím mu v ledačems vyhověti. “140 Ačkoli Bidlovo úmrtí Šustovi mimořádně zkomplikovalo redakční práce (jednu z napsaných kapitol zanechal Bidlo v trojnásobném rozsahu oproti požadované délce), ${ }^{141}$ byl poté jeho dlouholetý kolega mimořádně nápomocen vdově Marii Bidlové v otázkách proplácení honorářů a dalších záležitostech. ${ }^{142}$

Jednoznačně nejblíže byl Bidlovi po většinu doby společného působení na univerzitě Václav Novotný. K jejich postupnému sblížení docházelo od Bidlova pobytu v Rusku, kam mu Novotný na rozdíl od ostatních kolegů poměrně intenzivně psal. $\mathrm{V}$ jednom z dopisů si Bidlo např́ílad stěžoval: „Na můj dopis nikdo mi neodpověděl. Tobě vinu nedávám, spiše době. Doufám, že Ty budeš hodnější, nežli ten, od něhož jsem to očekával."143 Oba tehdy spojovalo také rozčarování z vývoje v redakci Českého časopisu historického, kde se dostával čím dál tím více ke slovu Pekař. ${ }^{144}$ Snad můžeme ve vztahu k Novotnému hovořit př́mo o prátelství, ${ }^{145}$ alespoň tak to Bidlo doslova formuloval v dopise nejstaršímu ze svých polských známých Feliksi Konecznému: „V poslední době mé velice dojala a rozrušila smrt Václava Novotného [...]. Byl to můj dobrý a vlastně jediný př́tel, se kterým ruku $v$ ruce jsem často bojoval se svými nepř́znivci a nepráteli, mezi které počítáme zejména také Pekaře. Ztráta Novotného je velkou ztrátou české historiografie a pro mě oslabení mé pozice v českém vědeckém životě." "146

\section{Žáci}

Jaroslav Bidlo asi nebyl právě pedagogem snů - je s velkou pravděpodobností jedním z mála profesorů české univerzity, jimž pověst coby obávaných zkoušejících zajistila místo i v krásné literatuře. Př́íhodu o tom, jak se českoamerický jezuita Josef Roubík (1888$1962)^{147}$ po vzoru jiného studenta duchovního stavu Bidlovi uklonil, zachytil Jakub Deml v nejznámějším ze svých pozdních textů (Podzimní sen) a zdrojem informace mu byl očitý svědek $-\mathrm{v}$ době vyprávění na začátku 50 . let někdejší profesor teologické fakulty, tehdy již internovaný $\mathrm{v}$ táboře pro nepohodlné duchovenstvo. Jedná se o vyprávění na téma ,jak se vyplácí zdvořilost" a Bidlo v něm figuruje doslova jako „obávaný profesor laik“. ${ }^{148}$

$\mathrm{S}$ tímto svědectvím se v podstatě shodují i vzpomínky studentů, různě bylo ale nahlíženo na Bidlovy faktické kompetence. Odhlédneme-li od Jana Slavíka, který na Bidlovi neshledával pozitivního vůbec nic, byl $\mathrm{k}$ jeho působení podobně kritický také František Michálek Bartoš, spatřující v něm ovšem podobně jako Slavík jednu z hlavních překážek

\footnotetext{
140 Jiř́ LACH, Josef Šusta a dějiny lidstva, Olomouc 2001, s. 62 (odtud citát), 77 a 84.

141 Tamtéž, s. 68.

142 Národní archiv, fond Josef Šusta, kart. 2, i. č. 16, dopisy M. Bidlové J. Šustovi.

143 MÚA, fond V. Novotný, kart. 8, i. č. 140, J. Bidlo V. Novotnému, 24. 11. 1897, Moskva. V podobném duchu i v následujícím listu z 23. 12. 1897.

144 D. Brádlerová - J. HÁleK (edd.), Jaroslav Bidlo - Milada Paulová. Střet generací?, s. 106n.

145 Autorka monografie o V. Novotném píše o „srdečném a korektním vztahu“. J. HoffmannovÁ, Václav Novotný, s. 154.

146 Dopis J. Bidla F. Konecznému z 27. 7. 1932 vydali P. BILIŃsKI - M. ĎurČAnsKÝ (edd.), Korespondencja Feliksa Konecznego z Jaroslavem Bidlo, s. 66.

147 Viz soupis disertačních prací oponovaných J. Bidlem. O Josefu Roubíkovi (Josephu Roubikovi, S. J.): <https:// www.myheritage.cz/names/joseph_roubik> (ověřeno 6. 7. 2019).

148 Jakub Deml, Podzimní sen, Olomouc 1992, s. 27.
} 
své habilitace. ${ }^{149}$ Podle něj Bidla (stejně jako Šustu) limitovaly ,silné kořeny katolictvi" Nejenže však ,trpěl touž vadou, nadto však i několika jinými, zejména př́krostí k posluchačưm “. ${ }^{150}$ Zdeněk Kalista, který byl zprvu podle vlastních vzpomínek Bidlovým oblíbeným žákem, ale pak dezertoval př́imo $\mathrm{k}$ jeho antipodu Pekařovi, vyčítal jeho přednáškám „slovní tvrdost a formální neobratnost", která byla v kombinaci s de facto středoškolským prrístupem - „školácky dřevěným přehledem dat a jmen“ - nesnesitelná. ${ }^{151}$ Svou roli ale hrála i malá atraktivita témat (byzantský raný stř̌edověk) a v př́ípadě vzpomínek je třeba vzít v úvahu právě to, že Kalista odešel z Bidlova prosemináře do Pekařova a stal se jedním z jeho nejdůležitějších žáků. Podle všeho se tak animozita přenesla z učitele na žáka (a naopak). Kalista byl nemile překvapen Bidlovou reakcí na svůj nástup na místo asistenta historického semináře, takže s odstupem konstatoval, že Bidlo ,jednal s každým posluchačem jako s imbecilem a i asistenta dovedl poniźit hlouběji než sluhu“. 152

Obraz, který zanechali Bidlovi následovníci a nejbližší spolupracovníci Josef Macůrek a Milada Paulová, je přece jen pozitivnější. Macůrek v nedokončených vzpomínkách uváděl, že mu vděčí za mnohé a že k němu Bidlo „býval vcelku vlídny““. Nesnesl ale odporování - symptomatické je, že v téže pasáži uvádí nutnost kriticky se vyrovnat s jeho názory na dějiny východní Evropy, což mohl učinit až po Bidlově smrti. ${ }^{153}$ Ještě o něco vstřícnější byla ve své osobní bilanci psané rovněž na sklonku života Paulová, která výslovně uvedla, že mu je nejvděčnější ze všech svých učitelů. V jejím hodnocení se zároveň objevuje kombinace sice př́sného, zato však ve vztahu ke studentům mimořádně obětavého učitele. Bidlo „byl tvrdý a neprístupný, potreboval-li však posluchač při práci pomoc, obstaráni materiálu, mohl k němu príjit', jak jsme si řikali, snad o půlnoci“ ${ }^{154}$ Měl také zájem o materiální zajištění studentů. 155

Koho Bidlo považoval za své žáky? Z jeho vlastních vzpomínek lze usoudit, že v prvé řadě studenty, u nichž významně ovlivnil výběr tématu a zpracování disertační práce. ${ }^{156}$ Bidlo sám v těchto souvislostech uváděl Emilii Procházkovou, Pavlu Suchou, Rudolfa Vindiše, Emanuela Janouška, Gertrudu Šaškovou, Jiř́ho Ryse a Marii Andrejevu. A k výčtu dodával: „Největšího úspěchu docílila Milada Paulová... Po ní pak Macưrek. Oba velmi krásně vypracovali témata mnou navržená a zůstali mými spolupracovníky a práteli. “157 Bidlo psal uvedený text na konci 20. let, proto je nutné z nejmladší vrstvy

149 Kateřina Anděroví, Osudy F. M. Bartoše a jeho vztah s V. Novotným ve světle jejich vzájemné korespondence, Marginalia historica 6, 2002, s. 105-191, zvl. s. 110, 155, 162.

${ }^{150}$ František Michálek BARToš, Vzpomínky husitského pracovnika, Praha 1970, s. 26n, podobně s. 34.

151 Z. Kalista, Po proudu života (2), s. 10.

152 Tamtéž, s. 62n.

153 J. MACŮREK, Úvahy o mé vědecké činnosti a vědeckých pracich, s. 55.

154 D. BrÁdlerová - J. HÁlek (edd.), Jaroslav Bidlo - Milada Paulová. Střet generací?, s. 144n.

155 Bohumil JiroušEK, Josef Klik. Historik ve stínu Josefa Pekaře, České Budějovice 2011, s. 27. Spolek posluchačů filozofie Univerzity Karlovy jej v kondolenci označil za „velkého přítele a učitele“. Po srovnání s kondolencemi adresovanými tímto studentským spolkem akademickému senátu po úmrtí jiných profesorů Filozofické fakulty ve 30. letech se domnívám, že se nejednalo o označení čistě formální. AUK, fond Akademický senát UK, i. č. 336, kart. 16, Spolek posluchačů filosofie UK Akademickému senátu UK, 3. prosince 1937.

156 Srov. př́lohu; disertačním pracím oponovaným J. Bidlem zamýšlím v blízké budoucnosti rovněž věnovat podrobnější statistickou a tematickou analýzu. Kvantitativní rozbor J. Hoffmannové přesvědčivě ukázal, že ordináři československých dějin byli ve srovnání s profesory všeobecných dějin v otázce posuzování disertačních prací přinejmenším dvojnásobně vytíženější (160 posudků V. Novotného!). J. HoffmannovÁ, Václav Novotný, s. 174 n.

157 Tamtéž, s. 66. 
jeho žáků tohoto typu uvést ještě alespoň Josefa Tichého, Jana Hertla a zejména zakladatele české sinologie Jaroslava Průška. U všech nepochybně ovlivnil vznik disertace a podle dochované korespondence sledoval jejich další osudy a kariéru. Za své žáky počítal také studenty navštěvující jeho seminář, zvláště pokud se sám přičinil o publikaci jejich prvních odborných prací v Časopise Matice moravské nebo Věstníku KČSN. V této souvislosti uváděl Václava Vojtíška, Bedřicha Jenšovského, Františka [Michálka] Bartoše, Františka Hrubého, Josefa Konopku a Jana Koláře. ${ }^{158}$ Blízko měli k Bidlovi také někteří jeho mladší kolegové z př́buzných oborů, jejichž kariérní vzestup podpořil - zmiňme alespoň spolueditory jeho jubilejního sborníku Josefa Dobiáše a Miloše Weingarta nebo Otakara Odložilíka.

Je ovšem nepochybné, že z mladších Bidlových žáků se mu už nikdo nedostal blíže než Josef Macůrek a Milada Paulová, kteří s ním doslova spojili svou kariéru. Po Bidlově smrti otázka jeho nástupnictví, při níž přicházeli v úvahu právě jen jeho dva nejbližší žáci, stejně jako otázka jeho vědeckého odkazu a písemné pozůstalosti, rezonovala v širším středoevropském měřítku. Josefa Macůrka se tak na osud Bidlových písemností dotazoval varšavský historik Marceli Handelsman ${ }^{159}$ nebo sudetoněmecký historik Josef Pfitzner, kteří s Bidlem oba polemizovali v diskuzi o pojetí východoevropských dějin. Pfitznerův dopis stojí (i s ohledem na jeho pozdější osudy) za obsáhlejší citaci: „Wahrscheinlich hätte ich Ihnen meinen Dank ${ }^{160}$ persönlich ausdrücken können, wenn mich nicht meine Erkrankung an der Teilnahme am Bidlo-begräbnis verhindert hätte. Damit haben Sie nun Ihren unmittelbaren Lehrer unerwartet rasch verloren und in die Reihen der tschechischen Historiker ist eine neue Lücke gerissen worden. Oft denke ich bei solchen Anlässen über die weitere Entwicklung der tschechischen Geschichtswissenschaft nach. Ohne Zweifel bekommt nun das mittlere und junge Geschlecht das Heft in die Hand. Mit Bidlo selbst verbanden mich ja leider mehr Meinungsverschiedenheiten als Uebereinstimmungen. Leider kam ich zu seinen Lebzeiten nicht mehr dazu, nochmals zur Frage Osteuropa zurückzukehren. Aber ich habe mir diese Arbeit als eine der nächsten vorgenommen. Wie steht es um Bidlos wissenschaftlichen Nachlass? Werden seine Vorlesungen über Osteuropa im Druck erscheinen, wie es Bidlo in der Polemik mit mir in Aussicht gestellt hat? Wer wird seinen Prager Lehrstuhl bekommen?"161

\section{Působení v profesorském sboru filozofické fakulty a v akademickém senátu. Děkanát}

Jak již bylo výše uvedeno, zasedání profesorského sboru filozofické fakulty se Bidlo účastnil od svého jmenování mimořádným profesorem, některé protokoly z jednání také sám zapisoval. ${ }^{162}$ Ze záležitostí, kterým se v prvních letech v rámci tohoto působení věno-

\footnotetext{
158 Tamtéž.

159 Archiwum PAN, Varšava, sign. III-10, pozůstalost M. Handelsmana, korespondence s J. Macůrkem.

160 Jednalo se o poděkování za zaslané publikace.

161 Archiv Masarykovy univerzity, fond B 88 Josef Macůrek, i. č. 333, J. Pfitzner J. Macůrkovi, 15. 12. 1937, Praha.

162 Dodejme, že zápis pořizoval obvykle někdo z mladších členů profesorského sboru. Ne vždy je v př́padě J. Bidla dochován původní vlastnoruční záznam, jako např. z 24. 10. 1907. AUK, FF UK, kart. 2, i. č. 26, protokol ze zasedání profesorského sboru FF UK-F. (Vedle toho ještě 28. 4. 1908.)
} 
val, můžeme uvést např́íklad otázku zastoupení univerzity na zemském sněmu, ${ }^{163}$ úpravu lektorátu slovanských jazyků, ${ }^{164}$ podávání disertací z oboru pomocných věd historických, ${ }^{165}$ podobu holdovacího projevu k šedesátiletému výročí panování Františka Josefa I., ${ }^{166}$ požadavky slovinských akademických spolků, ${ }^{167}$ remunerace lektorů cizích jazyků, 168 cestovní stipendium Vincence Lesného v roce 1911, ${ }^{169}$ užívání titulů doktor a docent, ${ }^{170}$ chod historicko-epigrafického semináře po smrti profesora Peroutky v roce 1912/13, ${ }^{171}$ změny rigorózního řádu ,pro kandidáty spojující studium historie s filologii slovanskou“. ${ }^{172} \mathrm{Z}$ iniciativy akademického senátu české univerzity byla na filozofické fakultě v roce 1912 zvolena komise „ohledně sepsání dějin university a fakultnich“ (tvořili ji Novotný, Bidlo a Pekař), ${ }^{173}$ nezdá se ale, že by reálně vyvíjela nějakou činnost. V akademickém roce 1912/1913 byl také zvolen jedním z devíti členů fakultní komise pro záležitosti soukromých docentů a lektorů (opakovaně v roce 1915). ${ }^{174} \mathrm{~V}$ téže době byl zvolen i nadačním referentem (zůstal jím až do léta $1915^{175}$ a o tři roky i šest let později byl zvolen do komise pro fondy a nadace ${ }^{176}$ ). Tehdy se pro změnu stal členem ,,komise pro věci sluhovské،. ${ }^{177} \mathrm{Na}$ sklonku války byl ještě zvolen do sedmičlenné komise, která měla reagovat na ministerský výnos „o zř́zení studii pro posluchače z války se vracejíci“ ${ }^{\prime 178}$

Podílel se samozřejmě také na habilitačních a profesorských řízeních svých mladších kolegů. Byl tak v roce 1910 členem příslušné komise při habilitaci Vlastimila Kybala v oboru všeobecných dějin středního a nového věku (společně s Gollem a Pekařem) ${ }^{179}$ a Antonína Šnajdaufa v oboru dějin výtvarného umění slovanského (společně s Gollem

163 AUK, FF UK, kart. 2, i. č. 26, protokol ze zasedání profesorského sboru FF UK-F, 28. 11. 1907.

164 Byl členem komise společně s Františkem Pastrnkem a Jiřím Polívkou. AUK, FF UK, kart. 2, i. č. 26, protokol ze zasedání profesorského sboru FF UK-F, 14. 5. 1908.

${ }^{165}$ Byl přijat společný návrh Františka Čády a Jaroslava Bidla, ,aby se v instrukcích uvedly pomocné vědy historické jakožto obor, $\mathrm{z}$ něhož disertace může býti podána ve spojení s dějinami všeobecnými nebo rakouskými nebo českými. “AUK, FF UK, kart. 2, i. č. 26, protokol ze zasedání profesorského sboru FF UK-F, 2. 7. 1908.

166 AUK, FF UK, kart. 2, i. č. 27, protokol ze zasedání profesorského sboru FF UK-F, 25. 11. 1908.

167 AUK, FF UK, kart. 2, i. č. 27, protokol ze zasedání profesorského sboru FF UK-F, 25. 2. a 4. 3. 1909.

168 Tamtéž, i. č. 29, protokol ze zasedání profesorského sboru FF UK-F, 12.1. 1911 a 16. 2. 1911. Podobně tamtéž, i. č. $35,26.10 .1916$ a i. č. $36,25.10 .1917$.

169 Tamtéž, i. č. 30, protokol ze zasedání profesorského sboru FF UK-F, 16. 11. 1911.

170 Tamtéž, i. č. 30, protokol ze zasedání profesorského sboru FF UK-F, 5. 7. 1912; tamtéž, i. č. 31, 16. 1. 1913.

171 Tamtéž, i. č. 31, protokol ze zasedání profesorského sboru FF UK-F, 16. 1. 1913 a 27. 2. 1913. Bidlo tehdy jménem komise navrhoval, ,,aby byl požádán dv[orní] rada Goll za občasné konání přednášek ze starověkého dějepisu“, patrně před nalezením vhodného Peroutkova nástupce.

172 Tamtéž, i. č. 35, protokol ze zasedání profesorského sboru FF UK-F, 26. 10. 1916.

173 Je zajímavé, že Pekař byl zvolen podstatně menším počtem hlasů než jeho kolegové (26:25:17). AUK, FF UK, kart. 2, i. č. 30, protokol ze zasedání profesorského sboru FF UK-F, 13. 6. 1912.

174 Tamtéž, i. č. 31, protokol ze zasedání profesorského sboru FF UK-F, 3. 7. 1913; tamtéž, i. č. 33, 8. 7.1915.

175 Tamtéž, i. č. 31, protokol ze zasedání profesorského sboru FF UK-F, 3. 7. 1913; tamtéž, i. č. 32, 20. 11. 1913, 15. 1. 1914, 9. 2. 1914, 12. 3. 1914, 18. 6. 1914; tamtéž, i. č. 33, 1. 10. 1914, 22. 10. 1914, 19. 11. $1914,21$. 1. 1915, 4. 3. 1915, 17. 6. 1915, 8. 7. 1915. Na postu nadačního referenta jej nahradil František Groh. V době jeho nepř́tomnosti byl Bidlo pověřován jeho zastupováním. AUK, FF UK, kart. 3, i. č. 38, protokol ze zasedání profesorského sboru FF UK, 19. 2. 1920.

176 AUK, FF UK, kart. 2, i. č. 36, protokol ze zasedání profesorského sboru FF UK-F, 13. 6. 1918; tamtéž, kart 3 , i. č. 39, protokol ze zasedání profesorského sboru FF UK, 16. 6. 1921.

177 AUK, FF UK, kart. 2, i. č. 33, protokol ze zasedání profesorského sboru FF UK-F, 8. 7. 1915.

178 Tamtéž, i. č. 36, protokol ze zasedání profesorského sboru FF UK-F, 7. 3. 1918.

179 Tamtéž, i. č. 28, protokol ze zasedání profesorského sboru FF UK-F, 13. 1. 1910, 21. 6. 1910 a 7. 7. 1910; K. KazBunda, Stolice dějin, III, s. 417n. 
a Niederlem, posléze rozšíŕena); ${ }^{180} \mathrm{v}$ roce 1911 komise při návrhu na jmenování Kamila Krofty mimořádným profesorem rakouského dějepisu (společně s Pekařem a Šustou) ${ }^{181}$ a habilitační komise Julia Glücklicha $\mathrm{z}$ oboru rakouských dějin (společně s Pekařem a Novotným), ${ }^{182}$ respektive Jaromíra Boreckého ,z jazyki̊ a literatur islámských“ (s J. Zubatým a R. Dvořákem); 183 o čtyři roky později pak členem habilitační komise Rudolfa Urbánka (společně $\mathrm{s}$ Pekařem a Novotným). ${ }^{184} \mathrm{~V}$ roce 1915 byla při ř́zení ke jmenování Václava Švambery řádným profesorem geografie na Bidlův návrh zvolena širši pětičlenná komise, ,jež by při sestavováni návrhu vzala v úvahu i postavení druhého prof. geografie“ (členy komise byli vedle Bidla V. Strouhal, L. Niederle, B. Kučera a F. Počta). ${ }^{185}$ Jakožto ordinář oboru obecných dějin samožrejmě nesměl chybět v komisích vyřizujících v roce 1917 návrh jmenování Vlastimila Kybala mimořádným profesorem tohoto oboru (společně s J. Šustou a V. Novotným) ${ }^{186}$ a o rok později návrh na povolání Bedřicha Hrozného z vídeňské univerzity jakožto mimořádného profesora klínopisného bádání a dějin starého orientu (společně s R. Dvořákem a J. Šustou). ${ }^{187}$

Jako jeden ze služebně nejmladších řádných profesorů byl Bidlo brzo po svém jmenování (konkrétně zhruba po půl roce, tj. 7. července 1911) zvolen členem výboru pro pořádání lidových přednášek českých vysokých škol pražských na rok 1911/1912. 188

Od jara 1914, kdy Bidlo působil jako referent pro nadační fondy, se začíná jeho jméno v protokolech ze zasedání profesorského sboru filozofické fakulty objevovat častěji. Svědčí to o rostoucím vlivu na vnitrofakultní záležitosti. ${ }^{189}$ Účastnil se pak např́klad debaty týkající se snah o zproštění vojenské povinnosti členů sboru, kteří „náležejí první domobranecké $v y ́ z v e \check{~ “ ‘ ~}{ }^{190}$ Věc se jej bytostně dotýkala, protože odchod na frontu potenciálně hrozil i jemu. V nedokončeném vzpomínkovém textu z léta 1915 uváděl v úvodu jako jednu z motivací: „Dne 11/8 jsem byl odveden-nemám zaručeno, nebudu-li konec konců přece muset sloužit ve vojsku a zdali ve zdraví prečkám nynějši hroznou válku."191

180 Habilitační žádost byla ovšem nakonec zamítnuta. AUK, FF UK, kart. 2, i. č. 28, protokol ze zasedání profesorského sboru FF UK-F, 23. 6. 1910; tamtéž, i. č. 29, 16. 2. 1911 a 23. 3. 1911.

181 AUK, FF UK, kart. 2, i. č. 29, protokol ze zasedání profesorského sboru FF UK-F, 16. 2. 1911 a 23. 3. 1911. K. Kazbunda, Stolice dějin, III, s. 402-404.

182 AUK, FF UK, kart. 2, i. č. 29, protokol ze zasedání profesorského sboru FF UK-F, 23. 3. 1911. Na jaře 1914 podával Bidlo úspěšně návrh, aby byla docentu Glücklichovi udělena dovolená. Tamtéž, i. č. 32, 30. 4. 1914. K. KazBunda, Stolice dějin, III, s. 437-440.

183 AUK, FF UK, kart. 2, i. č. 29, protokol ze zasedání profesorského sboru FF UK-F, 23. 3. 1911.

184 Tamtéž, i. č. 33, protokol ze zasedání profesorského sboru FF UK-F, 29. 4. 1915; tamtéž, i. č. 34, 27. 1. 1916.

185 Tamtéž, i. č. 33, protokol ze zasedání profesorského sboru FF UK-F, 21. 1. 1915, 17. 6. 1915.

186 Tamtéž, i. č. 35, protokol ze zasedání profesorského sboru FF UK-F, 7. 7. 1917. K. KazBunda, Stolice dějin, III, s. 419-425. V r. 1933 Bidlo s Šustou úspěšně navrhli, aby fakulta Kybalovi po letech v diplomatické službě obnovila veniam docendi. AUK, FF UK, kart. 5, i. č. 52, protokol ze zasedání profesorského sboru FF UK, 7. 12. 1933 .

${ }^{187}$ AUK, FF UK, kart. 2, i. č. 36, protokol ze zasedání profesorského sboru FF UK-F, 4. 7. 1918. Záhy po válce byl také členem komise projednávající návrh jmenování V. Kybala řádným profesorem. AUK, FF UK, kart. 3, i. č. 35, protokol ze zasedání profesorského sboru FF UK, 26. 6. 1919.

${ }^{188}$ MÚA, fond J. Bidlo, kart. 1, i. č. 1, rektor a ředitel univerzitní kanceláře J. Bidlovi, 10. července 1911, Praha.

${ }^{189} \mathrm{Na}$ jednom z posledních sezení profesorského sboru před vypuknutím světové války tak Bidlo navrhoval složení pětičlenné komise „k návrhu na udělení učebního příkazu doc. Rádlovi“, doporučoval udělení cestovní nadace Vlastimilu Kybalovi a dovolené na střední škole Karlu Chotkovi a vedle toho byly „vyslechnuty a schváleny nadační referáty prof. Bidla“. AUK, FF UK, kart. 2, i. č. 32, protokol ze zasedání profesorského sboru FF UK-F, 18. 6. 1914.

190 AUK, FF UK, kart. 2, i. č. 33, protokol ze zasedání profesorského sboru FF UK-F, 22. 10. 1914.

${ }^{191}$ Marek ĎurČAnsKý (ed.), Jaroslav Bidlo, Moje styky s Gollem, s. 659. 
Pro akademický rok 1915/1916 byl Jaroslav Bidlo zvolen děkanem fakulty. Ministerstvo volbu potvrdilo a vyhovělo jeho žádosti o snížení vyučovacích hodin na dvě týdně. ${ }^{192}$ Bidlo tak předsedal zasedáním profesorského sboru. Do období jeho děkanátu spadá úmrtí jeho učitele Josefa Kalouska a Františka hraběte Lützowa, které oba připomněl smutečním projevem. ${ }^{193}$ Nevyhnul se oficiálním projevům loajality, jako bylo zastupování rektora při otevření válečné výstavy v Muzeu Království českého, účast na dobročinném koncertu za př́tomnosti arcivévody Karla Štěpána v Obecním domě nebo bohoslužbách v Týnském chrámu u př́ležitosti 67. výročí nastolení Františka Josefa I. ${ }^{194}$

Horším problémem z hlediska národní loajality bylo suspendování T. G. Masaryka a vyškrtnutí Ernesta Denise z řad čestných doktorů České Karlo-Ferdinandovy univerzity. Protokol ze zasedání profesorského sboru 11. května 1916 obsahuje pouze stručnou informaci: „Po sděleni děkanově, že ho došly bezpečné zprávy, jak čestný doktor filosofické fakulty naši university prof. A. Denis v Pařiži v časopise ,La Nation tchèque dopouští se hrubých urážek proti nejjasnějš́mu panovnickému domu a vystupuje nepřátelsky proti mocnářství rakousko-uherskému, usneseno jednomyslně, aby prof. Denis byl vyškrtnut ze seznamu čestných doktorů naši university." 195

Bidla ve funkci děkana vystř́idal 26. ř́ina 1916 jeho spoluordinář Josef Šusta a poděkoval mu ,za vzorné vedeni úřadu“. ${ }^{196}$ Jak bylo tehdy běžné, Bidlo se stal na následující akademický rok proděkanem. S vývojem situace na bojištích ale bylo časem jasné, že se otázka Masarykovy profesury a Denisova čestného doktorátu ještě vrátí.

Ještě před vznikem Československa, na schůzi 24. října 1918, byl jednomyslně přijat návrh ,prof. Matiegky podepsaný většinou sboru, aby za neplatné bylo prohlášeno dřivějši vynucené usnesení sboru, jímž se rušil čestný doktorát francouzského historika Arnošta Denise“. ${ }^{197}$ Během následující schůze vznesli profesoři Zdeněk Nejedlý a František Slavík (mineralog) dotaz na iniciátora zrušení čestného doktorátu Arnošta Denise. Děkan Václav Novotný poté přečetl „důkladné memorandum tehdejšiho děkana prof. Bidla o průběhu celé záležitosti, což vzato na vědomi". Na návrh botanika Bohumila Němce měla být do memoranda děkanem ještě doplněna informace, že „tehdy před hlasováním žádná debata nebyla připuštěna“. 198

Záležitost s Masarykem a Denisem, ačkoli profesorský sbor při projednávání odnětí čestného doktorátu v roce 1918 žádné otevřené námitky vůči Bidlovi nevyslovil, představovala do budoucna potenciální problém. Ukázalo se to během jeho sporů s Janem Slavíkem, který jej na stránkách časopisu Sobota obvinil mj. z toho, že dal jako děkan filozofické fakulty vyškrtnout Masaryka ze seznamu univerzitních profesorů, aniž by jej $\mathrm{k}$ tomu někdo nutil. Fakulta tehdy požadovala na redakci časopisu s ohledem na tiskový zákon zveřejnění opravy. 199

192 MÚA, fond J. Bidlo, kart. 1, i. č. 1, děkanát Filozofické fakulty České Karlo-Ferdinandovy univerzity J. Bidlovi, 30. července 1915.

193 AUK, FF UK, kart. 2, i. č. 34, protokol ze zasedání profesorského sboru FF UK-F, 27. 1. 1916.

194 Tamtéž

195 Tamtéž, protokol ze zasedání profesorského sboru FF UK-F, 11. 5. 1916; Josef Petrán̆ - Lydia PetráñovÁ, Čestní doktoři Univerzity Karlovy 1848-2015, Praha 2017, s. 72.

196 AUK, FF UK, kart. 2, i. č. 35, protokol ze zasedání profesorského sboru FF UK-F, 26. 10. 1916.

197 AUK, FF UK, kart. 3, i. č. 36, protokol ze zasedání profesorského sboru FF UK-F, 24. 10. 1918.

198 AUK, FF UK, kart. 3, i. č. 36, protokol ze zasedání profesorského sboru FF UK-F, 28. 11. 1918. Memorandum je uloženo tamtéž, kart. 184, i. č. 1417. Srov. M. ĎURČAnsKÝ, Jaroslav Bidlo jako osoba veřejná, s. 60n.

199 AUK, FF UK, kart. 10, i. č. 102, osobní spis J. Bidla, čj. 2831/1931-32, koncept dopisu děkana FF UK M. Weingarta redaktorovi časopisu Sobota Karlu Jišovi, 25. 3. 1931, Praha (psán rukou J. Bidla). 
Přes veškerou loajalitu prokazovanou vůči Rakousku ale jinak nebyl Bidlo po vzniku Československa nijak vyšetřován, natož perzekvován. Naopak se zvýšila váha jeho postavení jakožto jediného československého ordináře oboru, zahrnujícího historickou slavistiku. Nyní bylo jeho zodpovědností nejen vychovat svého nástupce, ale také podílet se na personálním zajištění př́slušných kateder na nově založených univerzitách v Brně a Bratislavě. Ještě předtím byl ale pověřen rozsáhlými úkoly týkajícími se vybavení univerzitních pracovišst' v oboru historie základní slavistickou literaturou. ${ }^{200}$

V prvních měsících po převratu se v rámci profesorského sboru účastnil například debat o přesídlení německé univerzity, otázek reformy středních škol nebo zastoupení československého studentstva ve fakultních sborech (v této věci byl přijat Bidlův návrh na odpověd', že ,,v př́padě potřeby bude hleděno $k$ tomu, aby se vyhovělo“), ${ }^{201}$ dále například zř́zení zvláštních kurzů z historie, ekonomie a jazyků pro diplomatickou a konzulární službu. ${ }^{202}$

V meziválečném období byl Bidlo opět zvolen členem několika komisí projednávajících habilitace a profesury, at' už se jednalo o povolání historika Josefa Peiskera ze Štýrského Hradce do Prahy (společně s J. Pekařem a V. Novotným), ${ }^{203}$ ruského historika Nikolaje Jastrebova z Petrohradu do Prahy nebo na některou z nových československých univerzit (rovněž společně s J. Pekařem a V. Novotným). ${ }^{204}$ Byl členem habilitační komise Miloše Weingarta (obor slovanská filologie, společně s F. Pastrnkem a J. Polívkou), ${ }^{205}$ Františka Michálka Bartoše pro ,dějiny husitské، (s V. Novotným, J. Pekařem, J. Šustou a Z. Nejedlým), ${ }^{206}$ Josefa Dobiáše pro ,dějiny Řeki̊ a Římanư“، (s J. Šustou a F. Grohem), ${ }^{207}$ Vladimíra Groha (s F. Grohem a G. Friedrichem), ${ }^{208}$ Václava Vojtíška (s G. Friedrichem a V. Novotným), ${ }^{209}$ Karla Stloukala (s J. Šustou a J. Pekařem), ${ }^{210}$ Milady Paulové (s J. Šustou a M. Murkem), ${ }^{211}$

${ }^{200} \mathrm{~K}$ jeho postavení a úkolům v prvních letech ČSR srov. M. ĎuRČAnSKÝ, Jaroslav Bidlo jako osoba veřejná.

201 V̌̌e AUK, FF UK, kart. 3, i. č. 37, protokol ze zasedání profesorského sboru FF UK-F, 27. 2. 1919.

202 Tamtéž, protokol ze zasedání profesorského sboru FF UK-F, 3. 4. 1919.

203 Tamtéž, protokol ze zasedání profesorského sboru FF UK-F, 23. 1. 1919.

204 Tamtéž, protokol ze zasedání profesorského sboru FF UK-F, 23. 1. 1919 a 27. 2. 1919 (Jastrebov měl být nakonec povolán jako profesor slovanských dějin do Brna s právem přednášet v Praze do té doby, než bude jeho katedra fakticky zř́izena).

205 Tamtéž, protokol ze zasedání profesorského sboru FF UK-F, 27. 2. 1919 a 15. 3. 1919.

206 AUK, FF UK, kart. 3, i. č. 38, protokol ze zasedání profesorského sboru FF UK-F, 23. a 30. 10. 1919. Druhý pokus podnikl F. M. Bartoš v roce 1926, tehdy byli v komisi s Bidlem V. Novotný a J. Pekař. AUK, FF UK, kart. 3, i. č. 44, protokol ze zasedání profesorského sboru FF UK, 29. 4. a 20. 5. 1926.

207 Stejné složení měly i komise pro jeho jmenování mimořádným a řádným profesorem. AUK, FF UK, kart. 3, i. č. 41, protokol ze zasedání profesorského sboru FF UK, 26. 4. 1923; tamtéž, kart. 4, i. č. 47, protokol ze zasedání profesorského sboru FF UK, 31. 1. a 14. 31929.

208 AUK, FF UK, kart. 3, i. č. 39, protokol ze zasedání profesorského sboru FF UK, 3. 3. 1921.

209 Tamtéž, protokol ze zasedání profesorského sboru FF UK, 7. 7. 1921. V komisi pro jmenování V. Vojtíška mimořádným profesorem zasedli vedle J. Bidla G. Friedrich a J. Šusta. AUK, FF UK, kart. 4, i. č. 46, protokol ze zasedání profesorského sboru FF UK, 15. 5. 1927. V tomtéž složení zasedla komise posuzující návrh na jmenování řádným profesorem. AUK, FF UK, kart. 4, i. č. 50, protokol ze zasedání profesorského sboru FF UK, 14. 4. a 24. 5. 1932.

210 AUK, FF UK, kart. 3, i. č. 43, protokol ze zasedání profesorského sboru FF UK, 27. 11. 1924. V komisi pro jmenování K. Stloukala mimořádným profesorem zasedli vedle J. Bidla G. Friedrich a J. Šusta. AUK, FF UK, kart. 4, i. č. 49, protokol ze zasedání profesorského sboru FF UK, 18. 6. 1931; tamtéž, i. č. 50, protokol ze zasedání profesorského sboru FF UK, 3. 12. 1931.

211 AUK, FF UK, kart. 3, i. č. 43, protokol ze zasedání profesorského sboru FF UK, 29. 1., 19. 3. a 23. 4. 1925. Vedle Bidla a Šusty byl v př́ípadě komise pro jmenování M. Paulové mimořádnou profesorkou třetím členem slavista M. Weingart. AUK, FF UK, kart. 5, i. č. 52, protokol ze zasedání profesorského sboru FF UK, 25.1. a 17. 5. 1934. 
Otakara Odložilíka (s J. Šustou a J. Pekařem), ${ }^{212}$ Jaroslava Prokeše (s V. Novotným a J. Pekařem), ${ }^{213}$ Josefa Macůrka (s J. Šustou a V. Novotným), ${ }^{214}$ lektora lidové výchovy Jana Hořejšího z pedagogiky (s O. Kádnerem a F. Grohem), ${ }^{215}$ Antonína Uhlíře pro obor sociologie, ${ }^{216}$ Josefa Kratochvíla pro dějiny filozofie (s J. Králem a O. Kádnerem), ${ }^{217}$ Františka Štampacha pro obor pedagogiky (s O. Kádnerem a K. Chotkem) ${ }^{218}$ a Josefa Matouška pro obor novějších obecných dějin (s J. Šustou a G. Friedrichem). ${ }^{219}$ V případě některých z nich byl také členem komisí posuzujících jejich návrhy na mimořádné či řádné profesury (viz u příslušných osob v poznámkách). Vedle toho byl také členem komise pro jmenování Bedřicha Mendla mimořádným profesorem všeobecných hospodářských dějin (společně s J. Pekařem a J. Šustou), ${ }^{220}$ Bohumila Ryby mimořádným profesorem klasické filologie (s F. Grohem a O. Jiránim), ${ }^{221}$ Felixe Tauera mimořádným profesorem orientalistiky (s B. Hrozným, J. Rypkou a R. Růžičkou $)^{222}$ a Josefa Schránila řádným profesorem archeologie (s A. Salačem, J. Dobiášem a A. Matějčkem). ${ }^{223}$

Negativně zasáhl Bidlo do habilitačního řízení slavisty Josefa Páty, kdy přispěl k omezení veniae legendi pouze na obor lužické srbštiny, ${ }^{224}$ a v podobném duchu vystupoval při zrrízení stolice lužické srbštiny. ${ }^{225}$ Nepodařilo se mu ve smyslu jeho představ ovlivnit profesorský sbor při rozhodování o personálním obsazení nově zakládané stolice polonistiky, byt’ rozdíl v hlasování nebyl velký (10:8). ${ }^{226}$ Nejednalo se ovšem pouze o vlastní Filozofickou fakultu Univerzity Karlovy, Bidlo stál také u prvních slavistických profesur Univerzity Komenského, konkrétně byl členem komise pro jmenování komeniologa Jána Kvačaly (společně s J. Pekařem a V. Novotným) a Milana Hodži (s J. Pekařem a J. Jakubcem), ${ }^{227}$ a dokonce figuroval u habilitace N. Preobraženského pro dějiny severních Slovanů na univerzitě v Lublani. ${ }^{228}$ Zabýval se dále pozváním známého ruského historika umění N. P. Kondakova, působícího po odchodu z Ruska v Sofii, k smluvním přednáškám na

212 AUK, FF UK, kart. 3, i. č. 44, protokol ze zasedání profesorského sboru FF UK, 18. 3. 1926. V komisi pro jmenování O. Odložilíka mimořádným profesorem zasedli vedle J. Bidla V. Novotný a J. V. Šimák. AUK, FF UK, kart. 4, i. č. 49, protokol ze zasedání profesorského sboru FF UK, 22. 1. a 19. 3. 1931.

213 AUK, FF UK, kart. 3, i. č. 45, protokol ze zasedání profesorského sboru FF UK, 15. 6. 1927; AUK, FF UK, kart. 4, i. č. 46, protokol ze zasedání profesorského sboru FF UK, 15. 12. 1927.

214 AUK, FF UK, kart. 4, i. č. 48, protokol ze zasedání profesorského sboru FF UK, 31. 10. a 5. 12. 1929, 30.1. 1930. V případě návrhu na mimořádnou profesuru byli členy komise J. Rypka a J. Šusta (vedle J. Bidla). AUK, FF UK, kart. 5, i. č. 52, protokol ze zasedání profesorského sboru FF UK, 15. 3. a 14. 7. 1934.

215 AUK, FF UK, kart. 4, i. č. 50, protokol ze zasedání profesorského sboru FF UK, 28. 1. 1932.

216 AUK, FF UK, kart. 5, i. č. 51, protokol ze zasedání profesorského sboru FF UK, 27. 10. 1932.

217 Tamtéž, i. č. 52, protokol ze zasedání profesorského sboru FF UK, 25. 1. 1934.

218 Tamtéž, protokol ze zasedání profesorského sboru FF UK, 15. 3. 1934.

219 Tamtéž, i. č. 53, protokol ze zasedání profesorského sboru FF UK, 4. 4. 1935.

220 AUK, FF UK, kart. 4, i. č. 49, protokol ze zasedání profesorského sboru FF UK, 30. 10. 1930 a 12. 2.1931.

221 AUK, FF UK, kart. 5, i. č. 51, protokol ze zasedání profesorského sboru FF UK, 18. 5. a 14. 6. 1933.

222 Tamtéž, i. č. 52, protokol ze zasedání profesorského sboru FF UK, 14. 7. 1934.

223 Tamtéž, i. č. 52, protokol ze zasedání profesorského sboru FF UK, 14. 7. 1934; tamtéž, i. č. 53, protokol ze zasedání profesorského sboru FF UK, 6. 12. 1934.

224 AUK, FF UK, kart. 3, i. č. 40, protokol ze zasedání profesorského sboru FF UK, 24. 11. 1921 a 19. 1.1922.

225 Záležitost byla spojena s profesurou Josefa Páty; Bidlo podal v obou věcech minoritní votum. AUK, FF UK, kart. 4, i. č. 48, protokol ze zasedání profesorského sboru FF UK, 5. 12. 1929. Dále srov. AUK, FF UK, kart. 5, i. č. 52, protokol ze zasedání profesorského sboru FF UK, 14. 7. 1934; tamtéž, i. č. 53, protokol ze zasedání profesorského sboru FF UK, 6. 12. 1934.

226 AUK, FF UK, kart. 3, i. č. 40, protokol ze zasedání profesorského sboru FF UK, 11. 5. 1922.

227 Tamtéž, i. č. 39, protokol ze zasedání profesorského sboru FF UK, 25. 11. 1920.

228 Tamtéž, protokol ze zasedání profesorského sboru FF UK, 21. 4., 25. 5. a 16. 6. 1921. 
Filozofické fakultě Karlovy univerzity, 229 podobně o několik let později pověřením Dmytra Dorošenka přednáškami z ukrajinských a Alexandra Alexandroviče Kizevettera z ruských dějin, Alexandra Kolessy z ukrajinské literatury a jazyka, ${ }^{230}$ respektive Antonije Florovského z ruských dějin. 231

Z čestných doktorátů Bidlo přispěl k udělení tohoto ocenění Ludvíku Kubovi za jeho „zásluhy o poznání Slovanstva“.232 Často měl Bidlo co do činění se zvaním hostujících profesorů, což nebyla zvláště $\mathrm{v}$ době hospodářské krize jednoduchá záležitost, proto se vyjadřoval i $\mathrm{k}$ souvisejícím obecným zásadám ${ }^{233}$ a posléze se stal také členem př́islušné stálé komise. ${ }^{234}$

Z komisí zabývajících se organizačními záležitostmi fakulty zmiňme alespoň Bidlovo členství v komisích pro taxy, ${ }^{235}$ stipendia, ,pro otázku kursu pro legionáře, úpravu zkoušek a vydání učebnic“, pro rozdělení filozofické fakulty na „duchovědnou“ a prírodovědeckou, pro změnu rigorózního řádu, ${ }^{236}$ pro změnu habilitačního řádu, ${ }^{237}$ pro úpravu filozoficko-pedagogických zkoušek, ${ }^{238}$ pro „rozšíření učebního př́kazu“ profesora Bedřicha Hrozného, ${ }^{239}$ pro zaměstnání někdejších profesorů ruských univerzit, ${ }^{240}$ pro další vzdělávání absolventů učitelských ústavů, ${ }^{241}$ pro podmínky studia slovanských studentů (vyjma jihoslovanských), ${ }^{242}$

229 V př́slušné komisi zasedal s K. Chytilem a L. Niederlem. AUK, FF UK, kart. 3, i. č. 39, protokol ze zasedání profesorského sboru FF UK, 16. 6. a 7. 7. 1921. Tato komise také doporučovala následná prodlužování „učebního př́ikazu“. AUK, FF UK, kart. 3, i. č. 42, protokol ze zasedání profesorského sboru FF UK, 29. 11. 1923; tamtéž, i. č. 43, protokol ze zasedání profesorského sboru FF UK, 29. 1. 1925.

230 AUK, FF UK, kart. 3, i. č. 44, protokol ze zasedání profesorského sboru FF UK, 29. 4., 20. 5. a 18. 6.1926. Srov. také AUK, FF UK, kart. 4, i. č. 47, protokol ze zasedání profesorského sboru FF UK, 13. 6. 1929; tamtéž, i. č. 50, protokol ze zasedání profesorského sboru FF UK, 24. 5. 1932; tamtéž, kart. 5, i. č. 51, protokol ze zasedání profesorského sboru FF UK, 27. 4. 1933. V roce 1934 Bidlo urgoval jmenování A. Kolessy řádným profesorem, tamtéž, i. č. 52, protokol ze zasedání profesorského sboru FF UK, 14. 7. 1934.

231 AUK, FF UK, kart. 5, i. č. 54, protokol ze zasedání profesorského sboru FF UK, 19. 3. 1936; tamtéž, kart. 6, i. č. 55, protokol ze zasedání profesorského sboru FF UK, 29. 10. 1936.

232 AUK, FF UK, kart. 5, i. č. 54, protokol ze zasedání profesorského sboru FF UK, 19. 3. 1936.

233 AUK, FF UK, kart. 3, i. č. 44, protokol ze zasedání profesorského sboru FF UK, 26. 1. 1926.

234 AUK, FF UK, kart. 4, i. č. 46, protokol ze zasedání profesorského sboru FF UK, 27. 10. 1927 a 2. 2.1928. Srov. tamtéž, protokol ze zasedání profesorského sboru FF UK, 3. 4. 1930; tamtéž, i. č. 49, protokol ze zasedání profesorského sboru FF UK, 18. 6. 1931.

235 AUK, FF UK, kart. 3, i. č. 37, protokol ze zasedání profesorského sboru FF UK, 26. 6. 1919. Později byl členem komise pro úpravu rigorózních tax: tamtéž, kart. 4, i. č. 46, protokol ze zasedání profesorského sboru FF UK, 2. 2. a 22. 3. 1928.

236 AUK, FF UK, kart. 3, i. č. 38, protokol ze zasedání profesorského sboru FF UK, 23. a 30. 10. 1919. Při schvalování nového rigorózního řádu Bidlo jako jediný z profesorského sboru nesouhlasil s ustanovením, ,aby $\mathrm{v}$ př́ípadech, kdy pro obor kandidátovy disertace není profesora, byl examinátorem soukromý docent tohoto oboru“, tamtéž, kart. 3, i. č. 41, protokol ze zasedání profesorského sboru FF UK, 26. 4. 1923. Znovu tamtéž, kart. 5, i. č. 51, protokol ze zasedání profesorského sboru FF UK, 22. 6. 1933; tamtéž, i. č. 53, protokol ze zasedání profesorského sboru FF UK, 14. 3. a 16. 5. 1935; tamtéž, i. č. 54, protokol ze zasedání profesorského sboru FF UK, 5. 12. 1935.

${ }^{237}$ AUK, FF UK, kart. 3, i. č. 38, protokol ze zasedání profesorského sboru FF UK, 19. 2. 1920. Další komise (opět včetně členství J. Bidla) v podobné věci tamtéž, i. č. 43, protokol ze zasedání profesorského sboru FF UK, 29. 1. a 19. 3. 1925. Bidlo byl rovněž členem komise, která se zabývala oprávněností podávání habilitačních žádostí uchazečů, kteří již byli odmítnuti na jiných univerzitách. AUK, FF UK, kart. 5, i. č. 52, protokol ze zasedání profesorského sboru FF UK, 26. 10. 1933.

238 AUK, FF UK, kart. 3, i. č. 38, protokol ze zasedání profesorského sboru FF UK, 27. 5. 1920, 17. 6. 1920.

239 Tamtéž, protokol ze zasedání profesorského sboru FF UK, 6. 7. 1920.

240 Tamtéž, i. č. 39, protokol ze zasedání profesorského sboru FF UK, 27. 1. 1921.

241 Tamtéž, protokol ze zasedání profesorského sboru FF UK, 3. 3. 1921; tamtéž, i. č. 40, protokol ze zasedání profesorského sboru FF UK, 11. 5. 1922.

242 AUK, FF UK, kart. 3, i. č. 39, protokol ze zasedání profesorského sboru FF UK, 3. 3. 1921. 
pro čestné doktoráty, ${ }^{243}$ pro zrušení slavnostní promoce, ${ }^{244}$ pro posouzení návrhu MŠANO na zavedení numeru clausu pro první ročníky, ${ }^{245}$ pro habilitace ze sociotechniky, ${ }^{246}$ pro návrh na změnu maturitních vysvědčení, ${ }^{247}$ pro sociální a právní poměry vysokoškolských asistentů, ${ }^{248}$ pro úpravu ,postavení historické vlastivědy k platnému rigorosnímu rádu“ ${ }^{249}$ pro vydávání fakultní ročenky, ${ }^{250}$ pro projednání žádostí studentstva, ${ }^{251}$ pro „soustředění dotační agendy na kvestuře“, pro posouzení „možnosti kombinace oborů dějiny umění - české dějiny při rigorosech", pro státní ceny ve vědě a umění, ${ }^{252}$ pro dovolené mladších vědeckých pracovníků, ${ }^{253}$ pro zřízení stolice lidovýchovy, ${ }^{254}$ pro vypracování nových zásad pro obsazování profesorských stolic, ${ }^{255}$ pro semitskou filologii jako hlavní předmět rigoróza, ${ }^{256}$ pro nostrifikaci ruských akademických titulů, ${ }^{257}$ pro opatření oboru sociologie po odchodu F. Foustky, ${ }^{258}$ pro zrrízení etnografického semináře, ${ }^{259}$ pro doplňovací zkoušky z řečtiny, ${ }^{260}$ pro otázky psychotechnických zkoušek nově zapsaných posluchačů, ${ }^{261}$ pro úpravu přednášek ze sociologie, ${ }^{262}$ pro honoráře za přednášky a cvičení, ${ }^{263}$ pro řízení „,epigrafického a řeckého

243 Tamtéž, i. č. 40, protokol ze zasedání profesorského sboru FF UK, 19. 1. 1921.

244 Tamtéž, i. č. 41, protokol ze zasedání profesorského sboru FF UK, 26. 4. 1921.

245 Tamtéž, i. č. 43, protokol ze zasedání profesorského sboru FF UK, 29. 1. a 19. 3. 1925.

246 Jednalo se o posouzení návrhu vyžadované ministerstvem školství a národní osvěty. AUK, FF UK, kart. 3 , i. č. 44, protokol ze zasedání profesorského sboru FF UK, 26. 11. 1925.

247 Tamtéž, i. č. 45, protokol ze zasedání profesorského sboru FF UK, 9. 12. 1926.

248 AUK, FF UK, kart. 4, i. č. 46, protokol ze zasedání profesorského sboru FF UK, 2. 2. a 22. 3. 1928. Bidlo také zastupoval fakultu v ,anketě“ MŠANO ve věci právního a platového postavení vysokoškolských asistentů a v rámci komise působil jako referent v této věci. Tamtéž, kart. 5, i. č. 51, protokol ze zasedání profesorského sboru FF UK, 23. 3. a 27. 4. 1933; tamtéž, i. č. 52, protokol ze zasedání profesorského sboru FF UK, 26. 10. 1933.

249 AUK, FF UK, kart. 4, i. č. 46, protokol ze zasedání profesorského sboru FF UK, 2. 2. 1928.

250 Tamtéž, protokol ze zasedání profesorského sboru FF UK, 3. 5. a 14. 6. 1928. S vydáváním byly ovšem spojeny různé peripetie a o čtyři roky později byla zvolena nová komise. AUK, FF UK, kart. 4, i. č. 50, protokol ze zasedání profesorského sboru FF UK, 10. 3. 1932.

251 Projednávané záležitosti se týkaly např. výše rigorózních tax a dalších poplatků. AUK, FF UK, kart. 4, i. č. 49, protokol ze zasedání profesorského sboru FF UK, 30. 10. 1930.

252 Tamtéž, i. č. 48, protokol ze zasedání profesorského sboru FF UK, 17. 6. 1930; tamtéž, i. č. 49, protokol ze zasedání profesorského sboru FF UK, 30. 10. 1930.

${ }^{253} \mathrm{~V}$ tomto př́padě se jednalo hlavně o tlak na MŠANO, aby jim nestavělo zbytečné překážky. AUK, FF UK, kart. 4, i. č. 48, protokol ze zasedání profesorského sboru FF UK, 30. 10. a 4. 12. 1930. Později nesla komise název „,pro udělování dovolených lektorům a docentům“. Tamtéž, kart. 5, i. č. 51, protokol ze zasedání profesorského sboru FF UK, 27. 10. 1932 a 18. 5. 1933; tamtéž, i. č. 52, protokol ze zasedání profesorského sboru FF UK, 19. 4. 1934.

254 AUK, FF UK, kart. 4, i. č. 49, protokol ze zasedání profesorského sboru FF UK, 22. 1., 19. 3. a 18. 6. 1931. S touto záležitostí souvisela práce personálně totožné komise pro uspořádání přednášek lektora dr. Hořejšího pro posluchače všech fakult. AUK, FF UK, kart. 5, i. č. 51, protokol ze zasedání profesorského sboru FF UK, 7. 12.1932 a 26. 1. 1933.

255 AUK, FF UK, kart. 4, i. č. 49, protokol ze zasedání profesorského sboru FF UK, 23. 4. a 21. 5. 1931.

256 Tamtéž, protokol ze zasedání profesorského sboru FF UK, 18. 6. 1931.

257 Tamtéž, i. č. 50, protokol ze zasedání profesorského sboru FF UK, 29. 10. a 3. 12. 1931. Komise pak byla svolávána i v konkrétních případech nostrifikací. Tamtéž, kart. 5, i. č. 51, protokol ze zasedání profesorského sboru FF UK, 26. 1. 1933; tamtéž, kart. 6, i. č. 55, protokol ze zasedání profesorského sboru FF UK, 11. 3. 1937.

258 AUK, FF UK, kart. 4, i. č. 50, protokol ze zasedání profesorského sboru FF UK, 3. 12. 1931 a 28. 1. 1932.

259 Tamtéž, protokol ze zasedání profesorského sboru FF UK, 3. 12. 1931.

260 Tamtéž, protokol ze zasedání profesorského sboru FF UK, 14. 4. a 24. 5. 1932.

261 Tamtéž, protokol ze zasedání profesorského sboru FF UK, 14. 4. a 16. 6. 1932; tamtéž, kart. 5, i. č. 51, protokol ze zasedání profesorského sboru FF UK, 7. 12. 1932; tamtéž, i. č. 52, protokol ze zasedání profesorského sboru FF UK, 7. 12. 1933.

262 AUK, FF UK, kart. 4, i. č. 50, protokol ze zasedání profesorského sboru FF UK, 24. 5. 1932; tamtéž, kart. 5, i. č. 51, protokol ze zasedání profesorského sboru FF UK, 27. 10. 1932 a 18. 5. 1933.

263 AUK, FF UK, kart. 5, i. č. 51, protokol ze zasedání profesorského sboru FF UK, 7. 12. 1932. 
seminář “ 264 pro úspory, ${ }^{265}$ pro změnu zkušebního řádu pro kandidáty učitelství na středních školách, ${ }^{266}$ či pro obsazení dvou uprázdněných stolic československých dějin. ${ }^{267}$

Opakovaně byl Bidlo volen členem „biblioteční komise“ (společně s Václavem Tillem). ${ }^{268} \mathrm{Když} \mathrm{byla} \mathrm{na} \mathrm{podzim} 1922$ ustavena komise , $k$ vypracování návrhu na oživení slavistických studii“, stal se jejím členem kromě „,v̌̌ech pp. slavistư“ také J. Bidlo. ${ }^{269}$ Stejně jako před válkou Bidlo zasahoval rovněž do otázek lektorátů cizích jazyků, konkrétně srbochorvatštiny, ${ }^{270}$ respektive staré řečtiny. ${ }^{271}$ Podílel se také na posuzování lektorátu statistiky. ${ }^{272} \mathrm{~V}$ roce 1921 vyvolal jeho návrh na zř́zení žurnalistických kurzů při filozofické a právnické fakultě intenzivní debatu, jejímž předmětem byl hlavně vztah zamýšlených kurzů k univerzitním extenzím a výsledkem vznik další komise a posléze kuratoria, jehož členem byl Bidlo zvolen. ${ }^{273}$ Veřejný ohlas se očekával při zveřejnění postoje fakulty k ministerskému návrhu na reformu výuky na občanských a vysokých školách, kdy se Bidlo na př́íslušných krocích podílel s F. Grohem; ${ }^{274}$ podobná publicita se očekávala rovněž od memoranda pro reformu středních škol v roce $1932 .{ }^{275} \mathrm{~S}$ F. Grohem byl také na začátku akademického roku 1931/1932 zvolen do fakultní komise seniorů místo A. Musila a V. Franceva. ${ }^{276}$ Třričlenná komise seniorů se podílela např́iklad na prrípravě jednacího řádu profesorského sboru, který měl nahradit starší normativ z roku 1889. ${ }^{277}$ Členství v komisi seniorů se vzdal na konci roku 1935 ze zdravotních důvodů. ${ }^{278}$

Z celouniverzitních orgánů byl Bidlo od roku 1916 až do své smrti členem archivní komise. Stal se jím patrně jako děkan v roce 1916, kdy byl rektorem pověřen revizí

264 Tamtéž, protokol ze zasedání profesorského sboru FF UK, 18. 5. 1933; tamtéž, i. č. 52, protokol ze zasedání profesorského sboru FF UK, 26. 9. a 7. 12. 1933.

265 Tamtéž, i. č. 52, protokol ze zasedání profesorského sboru FF UK, 26. 10. 1933.

266 Tamtéž, protokol ze zasedání profesorského sboru FF UK, 19. 4. 1934.

267 AUK, FF UK, kart. 6, i. č. 56, protokol ze zasedání profesorského sboru FF UK, 5. 5. 1937.

268 AUK, FF UK, kart. 3, i. č. 39, protokol ze zasedání profesorského sboru FF UK, 16. 6. 1921.

269 Dalšími členy z okruhu osob mimo jazykovědnou slavistiku byli L. Niederle, J. Janko a F. Drtina. AUK, FF UK, kart. 3, i. č. 41, protokol ze zasedání profesorského sboru FF UK, 26. 10. 1922.

${ }^{270} \mathrm{Na}$ jeho návrh měl prof. Matija Murko připravit jmenování gymnaziálních profesorů Moskovieviće a Procházky lektory srbochorvatštiny. AUK, FF UK, kart. 3, i. č. 39, protokol ze zasedání profesorského sboru FF UK, 21. 10. 1920.

271 Tamtéž, protokol ze zasedání profesorského sboru FF UK, 25. 5. 1921.

272 AUK, FF UK, kart. 5, i. č. 52, protokol ze zasedání profesorského sboru FF UK, 15. 3. 1934.

273 AUK, FF UK, kart. 3, i. č. 40, protokol ze zasedání profesorského sboru FF UK, 27. 10. a 24. 11. 1921. Ohledně Bidlova vztahu k univerzitním extenzím je třeba ještě zmínit epizodu z konce akademického roku 1921/1922, kdy dostal $v$ této souvislosti za úkol prohlédnout místnosti uvolněné seminářem pro dějiny umění a slovanským seminářem. AUK, FF UK, kart. 3, i. č. 40, protokol ze zasedání profesorského sboru FF UK, 5. 7. 1922. V následujícím roce se stal členem komise, která měla pro „lidové přednášky“ vypracovat nové stanovy. Tamtéž, i. č. 41, protokol ze zasedání profesorského sboru FF UK, 26. 10. a 23. 11. 1922, 25. 1. 1923. Do „místní extenze“ byl zvolen společně s V. Mathesiem, M. Hýskem a V. Lesným znovu v říjnu 1926. Tamtéž, kart. 3, i. č. 45, protokol ze zasedání profesorského sboru FF UK, 21. 10. 1926. Své působení v extenzích ukončil na vlastní žádost při volení kandidátů na jaře 1931. Tamtéž, kart. 4, i. č. 49, protokol ze zasedání profesorského sboru FF UK, 23. 4. 1931.

${ }^{274}$ AUK, FF UK, kart. 3, i. č. 41, protokol ze zasedání profesorského sboru FF UK, 17. 5. 1923. Podobně také v souvislosti s plánem na reformu středních škol, kdy Bidlo hájil důležitost řečtiny. Tamtéž, i. č. 43, protokol ze zasedání profesorského sboru FF UK, 19. 3. 1925.

275 I v tomto prŕípadě byl Bidlo členem příslušné komise. AUK, FF UK, kart. 4, i. č. 50, protokol ze zasedání profesorského sboru FF UK, 28. 1. a 10. 3. 1932.

276 Tamtéž, protokol ze zasedání profesorského sboru FF UK, 29. 10. 1931.

277 Tamtéž, protokol ze zasedání profesorského sboru FF UK, 28. 1. 1932.

278 Tamtéž, kart. 5, i. č. 54, protokol ze zasedání profesorského sboru FF UK, 5. 12. 1935. 
univerzitního archivu, který byl společným vlastnictvím české i německé univerzity, jež jej reálně spravovala. Dlouhodobý spor mezi oběma univerzitami zahrnoval řadu různých aspektů, na počátku roku 1916 byla aktuálně řešena otázka pravidelných revizí univerzitního archivu za účasti české i německé archivní komise a spor se Zemským archivem o vydání jedenácti úředních rukopisů předbělohorské univerzity (tzv. Oeconomica). Bidlo v této věci předložil akademickému senátu rozsáhlý referát a 1 . dubna 1916 byl zvolen předsedou personálně částečně obměněné archivní komise české univerzity, která zasedla ve složení Gustav Friedrich, Karel Kadlec, Václav Novotný a Miroslav Stieber. ${ }^{279}$ Jejím předsedou zůstal Bidlo i na sklonku války, kdy 25. října 1918 zaznamenal protokol o jejím jednání, jehož předmětem bylo iniciování další revize archivu. Než k ní mohlo dojít, převzali archiv po převratu zástupci české univerzity, klíče měly být z rozhodnutí Národního výboru svěřeny do úschovy jejího rektora, po čase ale bylo nutné obnovit běžný provoz. V březnu 1919 vyzval rektor české univerzity Karel Hermann-Otavský, aby byla provedena revize za účasti obou komisí. ${ }^{280}$ Česká komise se záhy nato sešla a navrhla, aby byl Gustav Friedrich pověren funkcí inspektora společného univerzitního archivu, zatímco dosavadní kancelářský úředník Josef Bergl, zajištující běžný chod archivu, by byl ponechán na svém místě. Revize se měli zúčastnit tři a tři zástupci obou komisí. Česká komise pak měla vypracovat návrh na nové podmínky pro společné užívání archivu. ${ }^{281}$ Reálně se pak otázkám univerzitního archivu za českou stranu věnoval především Gustav Friedrich a později Václav Vojtíšek. ${ }^{282}$ Bidlo je výslovně uváděn v souvislosti s archivní komisí ještě v roce 1934, kdy se vyjadřovala k plánu Václava Vojtíška na uspořádání výstavy cimélií z fondů univerzitního archivu. ${ }^{283}$

V rámci akademické samosprávy sice Bidlo na rozdíl od svých kolegů Josefa Pekaře a Gustava Friedricha nedosáhl nejvyšší mety - postu rektora, měl ale možnost ovlivnit celkové směřování Univerzity Karlovy jako člen akademického senátu. Byl jím zvolen na tři školní roky: 1933/1934 - 1935/1936, tedy v době rektorátu Karla Domina a Josefa Drachovského. ${ }^{284} \mathrm{~V}$ prvním roce se vedle vypjatého nacionalismu musel akademický senát vyrovnávat také s návrhy na omezení (či př́mo rušení) vysokých škol z ekonomických důvodů. Tak jako v prípadě profesorského sboru Filozofické fakulty Univerzity Karlovy měl J. Bidlo přiděleny coby referent některé konkrétní spisy a kauzy (jako byla např́iklad ,úprava hmotného postavení ruských profesorů působícich na univerzite““285) nebo se

${ }^{279}$ Srov. zejména referát J. Bidla adresovaný akademickému senátu (3. března 1916) a protokol o schůzi univerzitní archivní komise z 1. dubna 1916. AUK, fond Akademický senát UK, kart. 53, i. č. 796a. Bidlovou vlastní rukou psané poznámky týkající se předpisů univerzitního archivu a koncept začátku memoranda adresovaný akademickému senátu české univerzity (7. 7. 1916) svědčí o tom, že těžiště jeho působení v univerzitní archivní komisi opravdu spadá do období jeho děkanátu. MÚA, J. Bidlo, kart. 24, i. č. 1018.

${ }^{280}$ MÚA, J. Bidlo, kart. 24, i. č. 1018, Protokol o schůzi české univerzitní archivní komise, 25. 10. 1918; tamtéž, K. Hermann-Otavský J. Bidlovi, 22. 3. 1919.

281 Tamtéž, Protokol o schůzi české univerzitní archivní komise, 1. 4. 1919 (Bidlův autograf podepsaný také ostatními členy komise).

282 Přehledně Karel KuČERA - Miroslav TRUc, Archiv University Karlovy. Průvodce po archivnich fondech, Praha 1961, s. 45-47.

283 AUK, fond Akademický senát UK, kart. 53, i. č. 769, protokol o schůzi univerzitní archivní komise z 23. ledna 1934.

${ }^{284}$ MÚA, fond J. Bidlo, kart. 1, i. č. 1, oznámení děkana Filozofické fakulty UK Jiřího Horáka J. Bidlovi o zvolení členem AS, 4. července 1933, Praha; AUK, FF UK, kart. 5, i. č. 51, protokol ze zasedání profesorského sboru FF UK, 18. 5. 1933.

${ }^{285}$ AUK, Akademický senát UK, kart. 44, i. č. 656, zápis ze zasedání AS UK, 20. 10. 1933, s. 17n. 
účastnil práce komisí, které byly pro jednotlivé záležitosti ad hoc sestavovány. ${ }^{286} \mathrm{~V}$ aktuálních otázkách insignií a přestavby Karolina zastával spiše umírněné stanovisko 287 a připomínal zásluhy Josefa Šusty na postu ministra školství a národní osvěty v záležitosti insignií a společného majetku české a německé univerzity. ${ }^{288} \mathrm{~V}$ posledním roce svého funkčního období v akademickém senátu byl zároveň členem disciplinární komise pro profesory a docenty Univerzity Karlovy. ${ }^{289}$ Lze předpokládat, že se jednalo o reakci na jeho návrhy pravděpodobně $\mathrm{v}$ akademickém senátu všeobecně príjatelné - během projednávání kauzy profesora Vladimíra Heinricha a Astronomického ústavu, kterou prostřednictvím periodika $A$-Zet sledovala široká veřejnost. ${ }^{290}$ Členství v akademickém senátu se Bidlo vzdal na podzim 1935 ze zdravotních důvodů. ${ }^{291}$

Cílem dosavadního únavného výčtu Bidlovy úřední činnosti a jeho akademických funkcí bylo na základě podrobné heuristiky ukázat, $\mathrm{v}$ čem spatřovali př́slušníci akademické obce jeho odborné kompetence, resp. také v čem je spatřoval on sám. Je zřejmé, že vedle funkcí souvisejících s jeho vlastním oborem docházelo k poměrně častým překryvům se „sousedními“ obory - jazykovědnou slavistikou, orientalistikou, dějinami filozofie, sociologií a zejména pedagogikou. Je třeba vzít v úvahu, že Bidlo měl ve srovnání s ostatními řediteli historického semináře společně s J. V. Šimákem, který učil na střední škole v letech 1897-1921, zdaleka největší středoškolskou pedagogickou praxi; zároveň byl vzhledem ke svému sociálnímu původu spjat s učitelskou profesí velmi úzce. Jeho pedantická povaha mu zároveň umožňovala nejen si množství nejrůznějších předpisů a řádů neošklivit, ale snad v nich dokonce i nalézat jisté zalíbení - alespoň se tak podle mého názoru dá soudit z jeho účasti v diskuzích v rámci jednání profesorského sboru Filozofické fakulty Univerzity Karlovy. Svou pravidelnou docházkou na zasedání hlavního fakultního samosprávného sboru i aktivní účastí v diskuzích a komisích patřil spíše k menšině profesorů.

\section{Závěr}

V dějinách české historické slavistiky má Jaroslav Bidlo své významné místo. Působení této zakladatelské osobnosti uvedeného oboru na Univerzitě Karlově se neomezovalo pouze na vlastní výuku, podrobná heuristika v pramenech úřední povahy umožnila ukázat také šíri jeho organizačního působení v jiných oblastech. Díky využití pramenů osobní povahy

${ }^{286}$ Byl tak členem komise, jež se měla vyslovit k podnětu vzešlému z Univerzity Komenského ohledně latinského překladu názvu Československé republiky a z něj odvozených adjektiv. AUK, Akademický senát UK, kart. 44, i. č. 657, zápis ze zasedání AS UK, 25. 3. 1935, s. 14, a 5. 4. 1935, s. 13n.

${ }^{287}$ AUK, Akademický senát UK, kart. 44, i. č. 656 a 657, zápis ze zasedání AS UK, 9. 3. 1934, s. 31, 33; zápis ze zasedání AS UK, 13. 4 1934, s. 28, 31n.; zápis ze zasedání AS UK, 1. 2. 1935, s. 20n. V diskuzích o přestavbě Karolina, kdy se řešilo také jeho budoucí využití po plánované výstavbě nové centrální budovy, Bidlo navrhoval, aby se stalo sídlem ČAVU a KČSN. Vedle toho pak odmítal věřit, že propagace přestavby Karolina jako celonárodní akce vzbudí podobně silné emoce srovnatelné s vyhlášením sbírky na stavbu Národního divadla. $\mathrm{K}$ Bidlovým starším snahám nalézt pro KČSN místo v rámci univerzitních areálů, např. právě v centrální budově, srov. AUK, FF UK, kart. 4, i. č. 49, protokol ze zasedání profesorského sboru FF UK, 18. 6. 1931.

288 AUK, Akademický senát UK, kart. 44, i. č. 656, zápis ze zasedání AS UK, 26. 1. 1934, s. 15.

${ }^{289}$ MÚA, fond J. Bidlo, kart. 1, i. č. 1, oznámení rektora UK Gustava Friedricha J. Bidlovi, 19. listopadu 1935, Praha a cyklostylovaný oběžník se složením komise.

290 AUK, Akademický senát UK, kart. 44, i. č. 656, zápis ze zasedání AS UK, 8. 6. 1934, s. 20-24.

291 AUK, FF UK, kart. 5, i. č. 54, protokol ze zasedání profesorského sboru FF UK, 24. 10. 1935. 
pak bylo možné pokusit se nahlédnout na Bidlovu osobu také z lidské stránky - nelze přehlížet, že určitý konfliktní potenciál v jeho povaze znesnadňoval každodenní soužití s ostatními kolegy. Nakolik převažovala pozitiva nad negativy, ukáže další výzkum zaměřený na Bidlovu činnost ve vědeckých společnostech a směřující k prípravě chybějící monografie o tomto významném členovi akademické obce meziválečné univerzity.

\section{Př́loha 1: Přednášky a semináře, které si J. Bidlo zapsal během studia na Filozofické fakultě České Karlo-Ferdinandovy univerzity 292}

\begin{tabular}{|c|c|c|c|}
\hline $\begin{array}{l}\text { Semestr / } \\
\text { Školní rok }\end{array}$ & Přednáška (hodinová dotace) & $\begin{array}{l}\text { Seminářr } \\
\text { (hodinová dotace) }\end{array}$ & Vyučující \\
\hline \multirow[t]{9}{*}{ ZS $1889 / 90$} & Dějiny rakouské a prameny jejich v 13. a 14. věku (3) & & Emler \\
\hline & Dějiny římské (2) & & Goll \\
\hline & Geografie římského světa (2) & & Palacký \\
\hline & Austrálie a Oceánie (1) & & Palacký \\
\hline & Ruská říše (1) & & Palacký \\
\hline & Soustavná mluvnice jazyka českého (5) & & Gebauer \\
\hline & Historická mluvnice jazyka německého (1) & & Mourek \\
\hline & Historie literatury německé doby staré (2) & & Mourek \\
\hline & Stručný náčrt nových směrů filosofických (1) & & Masaryk \\
\hline \multirow[t]{15}{*}{ LS $1889 / 90$} & O heraldice (3) & & Emler \\
\hline & Dějiny ř́ŕše německé a Itálie (4) & & Goll \\
\hline & O regestech (1) & & Emler \\
\hline & O českých letopiscích doby přemyslovské (1) & & Kalousek \\
\hline & Středověký zeměpis (1) & & Palacký \\
\hline & Soustavná mluvnice jazyka českého (4) & & Gebauer \\
\hline & O slovcích neohebných (1) & & Gebauer \\
\hline & Historie literatury německé doby střední (3) & & Mourek \\
\hline & Dějiny literatury české 16 . věku (2) & & Hattala \\
\hline & Fysikální zeměpis II. (2) & & Palacký \\
\hline & Dějiny římské (1) & & Goll \\
\hline & Dějiny uherského státního práva do r. 1867 (2) & & Rezek \\
\hline & Matematický zeměpis (2) & & Seydler \\
\hline & O Schillerovi (2) & & Kraus \\
\hline & O původě řeči (2) & & Hattala \\
\hline \multirow[t]{2}{*}{ ZS 1890/91 } & $\begin{array}{l}\text { Dějiny říše rakousko-uherské se zvláštním zřetelem } \\
\text { na vývoj práva a správy (5) }\end{array}$ & & Rezek \\
\hline & & $\begin{array}{l}\text { Cvičení } \\
\text { palaeografická (2) }\end{array}$ & Emler \\
\hline
\end{tabular}

${ }^{292}$ MÚA, J. Bidlo, kart. 1, i. č. 2, index a nedatovaný ověřený výpis. 


\begin{tabular}{|c|c|c|c|}
\hline & Dějiny říše německé a Itálie v středověku, část 4. (3) & & Goll \\
\hline & Dějiny výprav křižových (3) & & Jireček \\
\hline & Historický zeměpis 14 . století (1) & & Palacký \\
\hline & Střední Evropa (1) & & Palacký \\
\hline & Politický zeměpis (1) & & Palacký \\
\hline & Praktická filosofie (4) & & Durdík \\
\hline & O jednoduchých větách nářečí slovanských (2) & & Hattala \\
\hline & Soustavná mluvnice jazyka českého (Nauka o slově) (5) & & Gebauer \\
\hline & Historie literatury německé (2) & & Mourek \\
\hline & Dějiny filosofie 19 . století (2) & & Masaryk \\
\hline \multirow[t]{12}{*}{ LS 1890/91 } & & $\begin{array}{l}\text { Cvičení } \\
\text { palaeografická (2) }\end{array}$ & Emler \\
\hline & Dějiny 15 . století (5) & & Goll \\
\hline & Politický zeměpis II. část (pokračování) (1) & & Palacký \\
\hline & $\begin{array}{l}\text { Soustavná mluvnice jazyka českého (Nauka o slově - } \\
\text { pokračování) (5) }\end{array}$ & & Gebauer \\
\hline & O metodice zeměpisu a dějepisu (1) & & P. Durdík \\
\hline & Dějiny Čech a Uher 1648-1705 (2) & & Rezek \\
\hline & Nejstarší dějiny rakouské (3) & & Emler \\
\hline & Byzantské dějepisné prameny (2) & & Jireček \\
\hline & Národopis III. (3) & & Palacký \\
\hline & O staročeských legendách vůbec a rýmovaných zvláště (2) & & Hattala \\
\hline & Historie literatury německé (3) & & Mourek \\
\hline & Novější literatura rakouského dějepisu (1) & & Rezek \\
\hline \multirow[t]{14}{*}{ ZS 1891/92 } & Dějiny 16. století (5) & & Goll \\
\hline & Dějiny východní otázky 1683-1830 (3) & & Jireček \\
\hline & Úvod do antického zeměpisu a národopisu (2) & & Jireček \\
\hline & Dějiny české věku poděbradského a jagellonského (3) & & Kalousek \\
\hline & Fyzikální zeměpis (3) & & Palacký \\
\hline & Rakousko (1) & & Palacký \\
\hline & Dějiny literatury české 15 . století (3) & & Hattala \\
\hline & Česká literatura básnická až do doby Komenského (4) & & Gebauer \\
\hline & Historický přehled českého časování (1) & & Gebauer \\
\hline & Dějiny řecké filosofie (2) & & Drtina \\
\hline & O dramatické hudbě naší doby (1) & & Hostinský \\
\hline & Vnější organizace gymnázia (1) & & P. Durdík \\
\hline & Srovnávací mluvnice jazyků slovanských (2) & & Polívka \\
\hline & Sloveso v nové němčině (2) & & Kraus \\
\hline \multirow[t]{2}{*}{ LS 1891/92 } & Dějiny anglické ve středověku (2) & & Goll \\
\hline & Dějiny východní otázky, část II. (2) & & Jireček \\
\hline
\end{tabular}




\begin{tabular}{|l|l|l|l|}
\hline & Fyzikální zeměpis (pokračování) (3) & & Palacký \\
\hline & Repetitorium rakouských dějin (2) & & Rezek \\
\hline & Historický výklad českého časování (pokračování) (2) & & Gebauer \\
\hline & Čechy a Prusy ve středověku (1) & & Goll \\
\hline & & $\begin{array}{l}\text { Cvičení } \\
\text { palaeografická (2) }\end{array}$ & Emler \\
\hline & Dějiny české za prvních králů z rodu rakouského (3) & & Kalousek \\
\hline & Gymnaziální pedagogika (1) & $\begin{array}{l}\text { Semináŕ } \\
\text { historický (2) }\end{array}$ & Po. Durdík \\
\hline & & $\begin{array}{l}\text { Semináŕ } \\
\text { historický (2) }\end{array}$ & Rezek \\
\hline & & $\begin{array}{l}\text { Semináŕ } \\
\text { geografický (2) }\end{array}$ & Palacký \\
\hline & & $\begin{array}{l}\text { Semináŕ } \\
\text { slovanský (2) }\end{array}$ & Gebauer \\
\hline
\end{tabular}

\section{Příloha 2: Pedagogická činnost - přednášky J. Bidla na FF ČUK-F a FF UK v Praze 293}

\begin{tabular}{|l|l|l|}
\hline Studijní rok & Zimní semestr & Letní semestr \\
\hline $1900 / 01$ & Rusko a Polsko v 16. století & Rusko a Polsko v 16. století (dokončení) \\
\hline $1901 / 02$ & $\begin{array}{l}\text { Dějiny národů slovanských } \\
\text { (v přehledu) }\end{array}$ & Rusko za Petra Velikého \\
\hline $1902 / 03$ & Rusko v době Kateřiny II. & Rusko v době Kateřiny II. (dokončení) \\
\hline $1903 / 04$ & Dějiny říše byzantské I. & Dějiny říše byzantské II. \\
\hline $1904 / 05$ & Dějiny říše byzantské III. & Dějiny říše byzantské IV. \\
\hline $1905 / 06$ & $\begin{array}{l}\text { Úvod do dějin polských (O pramenech } \\
\text { a literatuře) } \\
\text { Dějiny Ruska v 19. století }\end{array}$ & $\begin{array}{l}\text { Dějiny Ruska v 19. století (dokončení) } \\
\text { Dějiny unie polsko-litevské }\end{array}$ \\
\hline $1906 / 07$ & $\begin{array}{l}\text { Dějiny říše byzantské I. } \\
\text { Dějiny Ruska v 19. století (dokončení) }\end{array}$ & $\begin{array}{l}\text { Dějiny říše byzantské II. } \\
\text { Úvod do dějin ruských (O pramenech a literatuře) }\end{array}$ \\
\hline $1907 / 08$ & $\begin{array}{l}\text { Dějiny států balkánských od } \\
1204-1453\end{array}$ & $\begin{array}{l}\text { Dějiny státu balkánských od 1204-1453 } \\
\text { (pokračování) } \\
\text { Dějiny říše polsko-litevské od vymření Jagelloncu } \\
\text { (pokračování) }\end{array}$ \\
\hline $1908 / 09$ & $\begin{array}{l}\text { Dějiny států balkánských ve století 14. } \\
\text { a 15. } \\
\text { Dějiny Polska a Ruska v 17. století }\end{array}$ & $\begin{array}{l}\text { Úvod do dějin polských (O pramenech a literatuře) } \\
\text { Dějiny Polska a Ruska v 17. století (pokračování) }\end{array}$ \\
\hline
\end{tabular}

${ }^{293}$ Zpracováno na základě tištěných publikací vydávaných pro každý semestr, obvykle pod názvem Seznamy prednášek, které se budou konati na Universitě Karlově v Praze... (z fondu AUK). 


\begin{tabular}{|c|c|c|}
\hline 1909/10 & $\begin{array}{l}\text { Přehledné dějiny národů slovanských } \\
\text { Dějiny Polska a Ruska od konce } \\
\text { století } 17 .\end{array}$ & $\begin{array}{l}\text { Přehledné dějiny národů slovanských (dokončení) } \\
\text { Dějiny Polska a Ruska od konce století } 17 . \\
\text { (pokračování) }\end{array}$ \\
\hline 1910/11 & $\begin{array}{l}\text { Dějiny Polska a Ruska od konce } \\
\text { 17. století (pokračování) }\end{array}$ & $\begin{array}{l}\text { Dějiny Polska a Ruska od konce 17. století } \\
\text { (pokračování) }\end{array}$ \\
\hline $1911 / 12$ & $\begin{array}{l}\text { Dějiny evropského východu ve } \\
\text { středověku } \\
\text { Ruský církevní rozkol v 17. století } \\
\text { (publicum) }\end{array}$ & $\begin{array}{l}\text { Dějiny evropského východu ve středověku } \\
\text { (pokračování) }\end{array}$ \\
\hline $1912 / 13$ & $\begin{array}{l}\text { Dějiny evropského východu ve } \\
\text { středověku } \\
\text { Dějiny východní a severní Evropy } \\
\text { v II. polovici } 16 . \text { století }\end{array}$ & $\begin{array}{l}\text { Dějiny evropského východu ve středověku } \\
\text { (pokračování) } \\
\text { Dějiny severní a východní Evropy v 17. století }\end{array}$ \\
\hline $1913 / 14$ & $\begin{array}{l}\text { Říše byzantská v době výprav } \\
\text { křížových (publice) } \\
\text { Dějiny východní a severní Evropy } \\
\text { v 17. století (pokračování) }\end{array}$ & $\begin{array}{l}\text { Říše byzantská v době výprav křǐžových } \\
\text { (dokončení) } \\
\text { Dějiny východní a severní Evropy v 17. století } \\
\text { (dokončení) }\end{array}$ \\
\hline $1914 / 15$ & $\begin{array}{l}\text { „R. prof. Dr. Bidlo má na studijní rok } \\
\text { 1914/15 od přednášek dovolenou“294 }\end{array}$ & $\begin{array}{l}\text { Dějiny balkánských států v 13. a 14. století } \\
\text { Dějiny východní a severní Evropy v 18. století }\end{array}$ \\
\hline $1915 / 16$ & $\begin{array}{l}\text { Dějiny evropského východu } \\
\text { ve středověku I. }\end{array}$ & Dějiny evropského východu ve středověku II. \\
\hline $1916 / 17$ & $\begin{array}{l}\text { Dějiny evropského východu } \\
\text { ve středověku III. }\end{array}$ & $\begin{array}{l}\text { Dějiny evropského východu ve středověku IV. } \\
\text { Otázka cyrillo-metodějská (publice) }\end{array}$ \\
\hline $1917 / 18$ & $\begin{array}{l}\text { Dějiny evropského východu } \\
\text { ve stř̌edověku V. }\end{array}$ & Dějiny evropského východu VI. \\
\hline 1918/19 & Dějiny evropského východu VII. & Dějiny evropského východu ve středověku VIII. \\
\hline 1919/20 & $\begin{array}{l}\text { Dějiny evropského východu } \\
\text { ve stř̌edověku IX. }\end{array}$ & Dějiny evropského východu ve středověku X. \\
\hline $1920 / 21$ & $\begin{array}{l}\text { Dějiny evropského východu } \\
\text { ve středověku XI. }\end{array}$ & Dějiny evropského východu ve středověku XII. \\
\hline $1921 / 22$ & Filosofie dějin východoevropských & Filosofie dějin východoevropských \\
\hline $1922 / 23$ & $\begin{array}{l}\text { Dějiny polabských a baltických } \\
\text { Slovanů } \\
\text { O literatuře k dějinám evropského } \\
\text { východu }\end{array}$ & $\begin{array}{l}\text { Dějiny polabských a baltických Slovanů } \\
\text { Literatura k dějinám evropského východu } \\
\text { (dokončení) }\end{array}$ \\
\hline $1923 / 24$ & $\begin{array}{l}\text { Dějiny byzantské od nastolení dynastie } \\
\text { syrské až do počátku výprav křížových }\end{array}$ & $\begin{array}{l}\text { Dějiny byzantské od počátku hnutí křížového } \\
\text { až do tzv. čtvrté výpravy křížové }\end{array}$ \\
\hline $1924 / 25$ & „má dovolenou“ & „má dovolenou“ \\
\hline $1925 / 26$ & $\begin{array}{l}\text { Dějiny říše polsko-litevské od unie } \\
\text { lublínské }\end{array}$ & $\begin{array}{l}\text { Dějiny říše polsko-litevské od unie lublínské, } \\
\text { část II. }\end{array}$ \\
\hline $1926 / 27$ & $\begin{array}{l}\text { Dějiny říše polsko-litevské od unie } \\
\text { lublínské, část III. } \\
\text { Dějiny Slovanů polabských } \\
\text { a baltických }\end{array}$ & $\begin{array}{l}\text { Dějiny říše polsko-litevské od unie lublínské, } \\
\text { část IV. } \\
\text { Dějiny Slovanů polabských a baltických } \\
\text { (dokončení) }\end{array}$ \\
\hline
\end{tabular}

${ }^{294}$ Srov. př́íis o zproštění J. Bidla povinnosti přednášet v akademickém roce 1914/1915; měl realizovat pouze seminární cvičení. Ministerstvo s návrhem fakulty souhlasilo výnosem ze dne 23. dubna 1914. MÚA, fond J. Bidlo, kart. 1, i. č. 1. 


\begin{tabular}{|l|l|l|}
\hline $1927 / 28$ & Přehled dějin východoevropských I. & Přehled dějin východoevropských II. \\
\hline $1928 / 29$ & Přehled dějin východoevropských III. & „má dovolenou“ \\
\hline $1929 / 30$ & $\begin{array}{l}\text { Dějiny říše polsko-litevské od unie } \\
\text { lublínské }\end{array}$ & $\begin{array}{l}\text { Dějiny říše polsko-litevské od unie lublínské } \\
\text { (pokračování) }\end{array}$ \\
\hline $1930 / 31$ & $\begin{array}{l}\text { Dějiny říše polsko-litevské od unie } \\
\text { lublínské, část III. }\end{array}$ & Dějiny říše polsko-litevské od unie lublínské \\
\hline $1931 / 32$ & $\begin{array}{l}\text { Dějiny evropského východu } \\
\text { ve středověku, část I. }\end{array}$ & Dějiny evropského východu ve středověku, část II. \\
\hline $1932 / 33$ & $\begin{array}{l}\text { Dějiny evropského východu } \\
\text { ve středověku, část III. }\end{array}$ & Dějiny evropského východu ve středověku \\
\hline $1933 / 34$ & $\begin{array}{l}\text { Dějiny evropského východu } \\
\text { ve středověku, část V. } \\
\text { Východoevropské dějepisectví }\end{array}$ & $\begin{array}{l}\text { Dějiny evropského východu ve středověku, } \\
\text { část VI. } \\
\text { Východoevropské dějepisectví }\end{array}$ \\
\hline $1934 / 35$ & $\begin{array}{l}\text { Dějiny evropského východu } \\
\text { ve středověku, část VII. } \\
\text { Východoevropské dějepisectví } \\
\text { (dokončení) }\end{array}$ & $\begin{array}{l}\text { Dějiny evropského východu ve středověku, } \\
\text { část VIII. } \\
\text { Východoevropské dějepisectví }\end{array}$ \\
\hline $1935 / 36$ & $\begin{array}{l}\text { Dějiny evropského východu od } \\
\text { XI. století }\end{array}$ & $\begin{array}{l}\text { Dějiny evropského východu od XI. století } \\
\text { (pokračování) }\end{array}$ \\
\hline $1936 / 37$ & $\begin{array}{l}\text { Dějiny evropského východu ve } \\
\text { 12. a 13. století }\end{array}$ & Dějiny evropského východu v 13. a 14. století \\
\hline $1937 / 38$ & $\begin{array}{l}\text { Dějiny evropského východu v 13. } \\
\text { a 14. století (dokončení) }\end{array}$ & \multicolumn{2}{|l}{} \\
\hline
\end{tabular}

\section{Príloha 3: Disertace recenzované Jaroslavem Bidlem ${ }^{295}$}

\begin{tabular}{|c|c|c|c|}
\hline $\begin{array}{l}\text { Číslo / } \\
\text { Akad. rok }\end{array}$ & Autor/autorka disertace & Název disertace & $\begin{array}{l}\text { Druhý } \\
\text { recenzent }\end{array}$ \\
\hline $\begin{array}{l}573 \\
1909 / 10\end{array}$ & Flégl Oldřich & Bratr Lukáš Pražský, theolog Jednoty bratrské & Goll \\
\hline $\begin{array}{l}590 \\
1910 / 11\end{array}$ & $\begin{array}{l}\text { Škerovič Nikola } \\
\text { /Černá Hora/ }\end{array}$ & Duro Križanič, njegograd i ideje & Polívka \\
\hline $\begin{array}{l}658 \\
1911 / 12\end{array}$ & Kolář Jan & $\begin{array}{l}\text { Monofysitismus, jeho vznik, vývoj a vliv } \\
\text { na dějiny říše byzantské }\end{array}$ & Pekař \\
\hline $\begin{array}{l}672 \\
1912 / 13\end{array}$ & Konopka Josef & $\begin{array}{l}\text { Separační snahy Moravanů na generálním sněmu } \\
\text { r. } 1611\end{array}$ & Novotný \\
\hline $\begin{array}{l}690 \\
1912 / 13\end{array}$ & Bartoš František & K počátkům Petra Chelčického & Novotný \\
\hline $\begin{array}{l}728 \\
1913 / 14\end{array}$ & Lameš Jaroslav & $\begin{array}{l}\text { Papežství, Karlovci a vláda byzantská od počátku } \\
\text { boje proti obrazúm až po korunování Karla } \\
\text { Velikého na císaře a smrt císařovny Ireny }\end{array}$ & Šusta \\
\hline $\begin{array}{l}809 \\
1915 / 16\end{array}$ & Herain Karel & $\begin{array}{l}\text { České malířství od doby rudolfinské do smrti } \\
\text { Reinerovy }\end{array}$ & Chytil \\
\hline
\end{tabular}

295 Zpracováno na základě tištěného soupisu: Marie Tulachová (ed.), Disertace pražské university 1882-1953, I, Praha 1965, dle rejstř́ku. 


\begin{tabular}{|c|c|c|c|}
\hline $\begin{array}{l}839 \\
1915 / 16\end{array}$ & Berka Čeněk & $\begin{array}{l}\text { Polsko za českého krále Václava II. a Ladislava } \\
\text { Lokýtka do r. } 1320\end{array}$ & Šusta \\
\hline $\begin{array}{l}935 \\
1917 / 18\end{array}$ & Nebeský Jaroslav & $\begin{array}{l}\text { Monastýr Žiča, príklad tzv. románského slohu } \\
\text { v Srbsku }\end{array}$ & Chytil \\
\hline $\begin{array}{l}938 \\
1918 / 19\end{array}$ & Letošník Václav & $\begin{array}{l}\text { Výprava krále Sigmunda III. proti Moskvě } \\
\text { a obléhání hradu Smolenska } 1610\end{array}$ & Šusta \\
\hline $\begin{array}{l}984 \\
1918 / 19\end{array}$ & Perićová Jela (Helena) & $\begin{array}{l}\text { Povijest Šibenika u 17. st. s osobitim pogledom } \\
\text { na Bandijské rat }\end{array}$ & Šusta \\
\hline $\begin{array}{l}1001 \\
1919 / 20\end{array}$ & Böhnel Bedřich Miroslav & $\begin{array}{l}\text { Prameny Historického kalendáře Daniela Adama } \\
\text { z Veleslavína }\end{array}$ & Novotný \\
\hline $\begin{array}{l}1076 \\
1920 / 21\end{array}$ & Šejtanov Najden Chr. & $\begin{array}{l}\text { Výprava císaře Symeona r. } 913 \text { podle kroniky } \\
\text { Symeona Metafrasta a Logotheta }\end{array}$ & Jastrebov \\
\hline $\begin{array}{l}1091 \\
1920 / 21\end{array}$ & Janoušek Emanuel & $\begin{array}{l}\text { Konfesse Jednoty bratrské od oddělení „Malé } \\
\text { stránky“ }\end{array}$ & Novotný \\
\hline $\begin{array}{l}1102 \\
1924 / 25^{296}\end{array}$ & Vindiš Rudolf & Bratra Lukáše Pražského názory na eucharistii & Novotný \\
\hline $\begin{array}{l}1118 \\
1921 / 22\end{array}$ & Květ Jan & $\begin{array}{l}\text { Německá říše a války proti husitům ve dvacátých } \\
\text { letech XV. století }\end{array}$ & Šusta \\
\hline $\begin{array}{l}1153 \\
1922 / 23\end{array}$ & Baušová Marie & Filip II. a koncil tridentský (1560-1563) & Šusta \\
\hline $\begin{array}{l}1201 \\
1923 / 24\end{array}$ & Melicharová Vlasta & Richelieu a řezenský sněm & Šusta \\
\hline $\begin{array}{l}1235 \\
1923 / 24\end{array}$ & Seton Walter Warren 297 & Nicholas Glassberg and his Works & Šusta \\
\hline $\begin{array}{l}1256 \\
1924 / 25\end{array}$ & Hájek Zdeněk & Styky Ruska s řriší byzantskou do konce X. století & Šusta \\
\hline $\begin{array}{l}1271 \\
1924 / 25\end{array}$ & Bas Vasyl & $\begin{array}{l}\text { Švédsko-ukrajinské styky za Bohdana } \\
\text { Chmelnyckého }\end{array}$ & Šusta \\
\hline $\begin{array}{l}1314 \\
1925 / 26\end{array}$ & Macůrek Josef & $\begin{array}{l}\text { Husitství v rumunských zemích, zvláště } \\
\text { v Moldavsku }\end{array}$ & Šusta \\
\hline $\begin{array}{l}1332 \\
1925 / 26\end{array}$ & Kajzermanová Eugenie & $\begin{array}{l}\text { Účastenství moskevského patriarchy v událostech } \\
\text { bouřlivé doby }\end{array}$ & Šusta \\
\hline $\begin{array}{l}1333 \\
1925 / 26\end{array}$ & Andrejeva Marie & $\begin{array}{l}\text { Kultura byzantského dvora podle Nikefora } \\
\text { Blemmyda }\end{array}$ & Šusta \\
\hline $\begin{array}{l}1345 \\
1925 / 26\end{array}$ & Savjak Petro & $\begin{array}{l}\text { Spis Pavla Oderborna „Vita Joannis Basilidis“ } \\
\text { (cara Ivana Hrozného) jako historický pramen }\end{array}$ & Šusta \\
\hline $\begin{array}{l}1376 \\
1925 / 26\end{array}$ & Williams John Emlyn & The Life of Edmund Burke & Šusta \\
\hline $\begin{array}{l}1385 \\
1925 / 26\end{array}$ & Terleckyj Markijan²98 & Breštská země v r. 1550-1650 & Šusta \\
\hline
\end{tabular}

296 Ačkoli je v tiššném seznamu disertací zařazena práce Rudolfa Vindiše na začátek 20. let, podle záznamů v matrice doktorů skládal rigorózní zkoušky v letech 1924-1925 a promován byl 26. června 1925. AUK, fond Matriky Univerzity Karlovy, i. č. 6, Matrika doktorů Univerzity Karlovy VI, s. 2519.

${ }^{297} \mathrm{~K}$ tomuto britskému historikovi srov. $<\mathrm{http}: / /$ www.thepeerage.com/p57443.htm> (ověreno 14. 7. 2019).

298 Návrh J. Bidla, aby práce mohla být předložena v ukrajinštině, schválil profesorský sbor FF UK. AUK, FF UK, kart. 3, i. č. 44, protokol ze zasedání profesorského sboru FF UK, 20. 5. 1926. 


\begin{tabular}{|c|c|c|c|}
\hline $\begin{array}{l}1418 \\
1926 / 27\end{array}$ & Janovyč Josef & Př́ičiny pádu Denikinova & Šusta \\
\hline $\begin{array}{l}1450 \\
1926 / 27\end{array}$ & Waskovitz George Joseph & $\begin{array}{l}\text { The political theory of Karel Havlíček and } \\
\text { contemporary Europe, especially Mazzini }\end{array}$ & Šusta \\
\hline $\begin{array}{l}1455 \\
1927 / 28\end{array}$ & Smetana Jaroslav & $\begin{array}{l}\text { Poměr Václava II. k Albrechtovi Rakouskému } \\
\text { v letech 1289-1292 }\end{array}$ & Šusta \\
\hline $\begin{array}{l}1459 \\
1927 / 28\end{array}$ & Šepovalov Alexander & Učení o národě u Montesquieua a Rousseaua & Šusta \\
\hline $\begin{array}{l}1476 \\
1927 / 28\end{array}$ & Čejchan Václav & M. A. Bakunin. Příspěvek k jeho životopisu & Šusta \\
\hline $\begin{array}{l}1490 \\
1928 / 29\end{array}$ & Gašparíková Anna & $\begin{array}{l}\text { Uhorské povstanie na začiatku 18. storočia } \\
\text { a jeho diplomatické vztahy k europskému západu } \\
\text { i východu do r. } 1708\end{array}$ & Šusta \\
\hline $\begin{array}{l}1492 \\
1927 / 28\end{array}$ & $\begin{array}{l}\text { Semanjuk Dmitrij } \\
\text { Onufrijevič }\end{array}$ & Polské a uherské poměry k halické Rusi & Šusta \\
\hline $\begin{array}{l}1513 \\
1927 / 28\end{array}$ & Kohnová Marie Jana & Amerikanisace Moravských Bratří & Šusta \\
\hline $\begin{array}{ll}1561 \\
1928 / 29\end{array}$ & Melniková Helena ${ }^{299}$ & $\begin{array}{l}\text { Styky česko-ruské v době českého obrození } \\
(1800-1848)\end{array}$ & Šusta \\
\hline $\begin{array}{ll}1572 \\
1928 / 29\end{array}$ & Čarněcký Mikuláš300 & Válka polsko-moskevská v 1. 1632-1634 & Šusta \\
\hline $\begin{array}{l}1605 \\
1929 / 30\end{array}$ & Svátek Richard & $\begin{array}{l}\text { Hrabě Leon Thun-Hohenstein až do jmenování } \\
\text { ministrem kultu a vyučování } 20 \text {. července } 1849 \text { - } \\
\text { v rámci soudobého duševního vývoje evropského }\end{array}$ & Šusta \\
\hline $\begin{array}{l}1624 \\
1929 / 30\end{array}$ & Hachnazarian Ovanes & $\begin{array}{l}\text { Politické styky Arménů s Ruskem v době Petra } \\
\text { Velikého }\end{array}$ & Šusta \\
\hline $\begin{array}{l}1659 \\
1929 / 30\end{array}$ & Eftimiu Helena & Poměr Moldavska k Polsku v letech 1387-1546 & Šusta \\
\hline $\begin{array}{l}1676 \\
1930 / 31\end{array}$ & $\begin{array}{l}\text { Poplavková-Kohnová } \\
\text { Alexandra }\end{array}$ & $\begin{array}{l}\text { Politika Francie vůči Rusku v době od } 18 . \\
\text { Brumaira do konce VIII. roku republiky }\end{array}$ & Šusta \\
\hline $\begin{array}{ll}1688 \\
1930 / 31\end{array}$ & Průšek Jaroslav & Ti a čínské státy v době Čou & Šusta \\
\hline $\begin{array}{l}1699 \\
1930 / 31\end{array}$ & Papoušek Jaroslav & Proč došlo k bojům legií se sověty & Šusta \\
\hline $\begin{array}{l}1803 \\
1932 / 33\end{array}$ & Roubík Josef & $\begin{array}{l}\text { The Contest over Jurisdiction against heretics } \\
\text { under the emperor Charles VI, covering years } \\
1719-1726\end{array}$ & Šusta \\
\hline $\begin{array}{l}1817 \\
1932 / 33\end{array}$ & Mrázek Jaroslav & $\begin{array}{l}\text { Woodrow Wilson a uznání Čsl. Nár. } \\
\text { Rady za vládu de facto Spojenými Státy } \\
\text { Severoamerickými }\end{array}$ & Šusta \\
\hline $\begin{array}{l}1835 \\
1933 / 34\end{array}$ & Kurfürst František & $\begin{array}{l}\text { Čechové v Rusku v době Petra Velikého. Jiří } \\
\text { z Drachova. Př́íspěvek k česko-ruským stykům } \\
\text { v posledních desítiletích stol. XVII. a počátkem } \\
\text { stol. XVIII. }\end{array}$ & Šusta \\
\hline
\end{tabular}

${ }^{299}$ Návrh J. Bidla, aby práce mohla být předložena v ruštině, schválil profesorský sbor FF UK. AUK, FF UK, kart. 4, i. č. 47, protokol ze zasedání profesorského sboru FF UK, 25. 10. 1928.

${ }^{300}$ V matrice jako Mikola Czarniecki. 


\begin{tabular}{|l|l|l|l|}
\hline $\begin{array}{l}1851 \\
1933 / 34\end{array}$ & Tichý Josef & $\begin{array}{l}\text { Jan Zamojski a rodina Zborowských do sněmu } \\
\text { roku } 1585^{301}\end{array}$ & Šusta \\
\hline $\begin{array}{l}1856 \\
1934 / 35\end{array}$ & Matysová Anna & Komenský jako politik & Šusta \\
\hline $\begin{array}{l}1900 \\
1934 / 35\end{array}$ & Şesan Milan Pavel & $\begin{array}{l}\text { Administrativní rozdělení byzantské ŕíše za vlády } \\
\text { Komnenovců a Anghelovcú }\end{array}$ & Šusta \\
\hline $\begin{array}{l}1921 \\
1934 / 35\end{array}$ & Myslivec Josef & Svatý Jiří ve východokřest’anském umění & Matějček \\
\hline $\begin{array}{l}1946 \\
1935 / 36\end{array}$ & Kalousek Jiří & Kam spěje Amerika? & Král \\
\hline $\begin{array}{l}1987 \\
1936 / 37\end{array}$ & Procházka Theodor & Počátky české migrace do Ameriky & Šusta \\
\hline $\begin{array}{l}2001 \\
1936 / 37\end{array}$ & $\begin{array}{l}\text { Červeňanská-Stuchlíková } \\
\text { Nuta }\end{array}$ & Tažení Rusů do Uher roku 1849 & Šusta \\
\hline
\end{tabular}

\section{Grantová podpora}

Tato studie vznikla jako výstup z projektu „Jaroslav Bidlo a Milada Paulová: zakladatelské osobnosti historické slavistiky v kontextu vývoje české vědy“, podpořeného Grantovou agenturou České republiky (grant č. 18-20451S, řešitel Marek Ďurčanský).

\section{MAREK ĎURČANSKÝ}

\section{Jaroslav Bidlo und die Prager Universität: zu den Anfängen der tschechischen historischen Slavistik}

\section{ZUSAMMENFASSUNG}

An der Wende vom 19. zum 20. Jahrhundert etablierte sich im mitteleuropäischen Raum die historische Slavistik allmählich als selbstständige Disziplin, für die an den Universitäten in Berlin, Prag und Wien selbstständige Professuren eingerichtet wurden. Obwohl diese Wissenschaftsdisziplin der traditioneller konzipierten linguistischen und literarhistorischen Slavistik näherstand, handelte es sich primär um ein historisches Fach, das in den Rahmen der allgemeinen Geschichte fiel. Auch war der Vertreter dieses Faches an der tschechischen Universität in Prag, Jaroslav Bidlo (1868-1937), Professor für ,allgemeine Geschichte mit besonderer Berücksichtigung der Geschichte Osteuropas und der Balkanländer“. Die Entwicklung der historischen Slavistik an der tschechischen Universität ist mit seiner langjährigen Tätigkeit (von der Habilitation 1900 bis zu seinem Tod) verbunden.

Bidlo stammte aus einer Lehrerfamilie und sollte ursprünglich Priester werden. Zwei Jahre im Priesterseminar in Hradec Králové haben zweifellos zu seinen Sprachfähigkeiten und seinem Sinn für Kirchengeschichte beigetragen. An der Philosophischen Fakultät der Böhmischen Karl-Ferdinands-Universität studierte er nicht nur im historischen Seminar von Josef Emler und Jaroslav Goll, sondern auch im slawischen Seminar des Sprachwissenschaftlers Jan Gebauer. Bidlo gehörte zu der ältesten Generation der sogenannten Gollschen Schule; schon während des Studiums lernte er seine späteren Kollegen und den (Co-)Direktor des historischen Seminars Václav Novotný, Josef Pekar̆ und Josef Šusta kennen. Ihre langjährige Zusammenarbeit, aber auch Differenzen, besonders

301 V tištěném soupise chybně uvedeno 1855. 
die Animosität zwischen Bidlo und Pekar̆, haben drei Jahrzehnte lang die Entwicklung der tschechischen Universitätsgeschichtsschreibung prinzipiell beeinflusst.

Unsere Studie verfolgt die Voraussetzungen Jaroslav Bidlos für seine Tätigkeit im Fach, sein Studium (einschließlich seiner Studienaufenthalte in Krakau, Moskau und Petersburg) und die Entwicklung seiner akademischen Laufbahn von der Habilitation bis zur ordentlichen Professur, die er 1910 erlangte. Es folgt eine Übersicht über Bidlos pädagogisches und organisatorisches Wirken an der Universität, die auf den Inhalt seiner Vorlesungen, auf die von ihm begutachteten Dissertationen und auf sein Verhältnis zu den Studenten und Kollegen abzielt. Relativ detailliert wird auf Bidlos Tätigkeit im Professorenkollegium der Philosophischen Fakultät und in den verschiedenen Fakultätskommissionen eingegangen. Höhepunkt des Vertrauens in Bidlos organisatorische Fähigkeiten war der Umstand, dass er in den dreißiger Jahren drei Jahre lang im akademischen Senat aktiv war. Eine Prüfung besonderer Art war für ihn seine Wahl zum Dekan der Philosophischen Fakultät 1915/1916, als er zwischen Loyalität gegenüber der Monarchie und seiner tschechischen Gesinnung balancieren musste (in die Zeit seines Dekanats fällt der Ausschluss T. G. Masaryks aus dem Professorenkollegium der Prager Universität und die Aberkennung des Ehrendoktors von Ernest Denis).

Die zwischenkriegszeitliche Tätigkeit Jaroslav Bidlos an der Karlsuniversität zeigt, wie durch Veränderung der geopolitischen Verhältnisse aus einer ursprünglich eher marginalen Disziplin eine vom Staat geförderte Schlüsseldisziplin werden konnte.

Marek Ďurčanský

Deutsche Übersetzung Wolf. B. Oerter

Ústav dějin a archiv UK, Praha

marek.d'určansky@ruk.cuni.cz 